

\section{AVAILABILITY OF BOOKS AND MAPS OF THE U.S. GEOLOGICAL SURVEY}

Instructions on ordering publications of the U.S. Geological Survey, along with prices of the last offerings, are given in the current-year issues of the monthly catalog "New Publications of the U.S. Geological Survey." Prices of available U.S. Geological Survey publications released prior to the current year are listed in the most recent annual "Price and Availability List." Publications that are listed in various U.S. Geological Survey catalogs (see back inside cover) but not listed in the most recent annual "Price and Availability List" are no longer available.

Prices of reports released to the open files are given in the listing "U.S. Geological Survey Open-File Reports," updated monthly, which is for sale in microfiche from the U.S. Geological Survey, Books and Open-File Reports Section, Federal Center, Box 25425, Denver, CO 80225. Reports released through the NTIS may be obtained by writing to the National Technical Information Service, U.S. Department of Commerce, Springfield, VA 22161; please include NTIS report number with inquiry.

Order U.S. Geological Survey publications by mail or over the counter from the offices given below.

\section{BY MAIL}

\section{Books}

Professional Papers, Bulletins, Water-Supply Papers, Techniques of Water-Resources Investigations, Circulars, publications of general interest (such as leaflets, pamphlets, booklets), single copies of Earthquakes \& Volcanoes, Preliminary Determination of Epicenters, and some miscellaneous reports, including some of the foregoing series that have gone out of print at the Superintendent of Documents, are obtainable by mail from

\section{U.S. Geological Survey, Books and Open-File Reports Federal Center, Box 25425 Denver, CO 80225}

Subscriptions to periodicals (Earthquakes \& Volcanoes and Preliminary Determination of Epicenters) can be obtained ONLY from the

\section{Superintendent of Documents \\ Government Printing Office \\ Washington, D.C. 20402} ments.)

(Check or money order must be payable to Superintendent of Docu-

\section{Maps}

For maps, address mail orders to

\section{U.S. Geological Survey, Map Distribution \\ Federal Center, Box 25286 \\ Denver, CO 80225}

Residents of Alaska may order maps from

\author{
Alaska Distribution Section, U.S. Geological Survey, \\ New Federal Building - Box 12 \\ 101 Twelfth Ave., Fairbanks, AK 99701
}

\section{OVER THE COUNTER}

\section{Books}

Books of the U.S. Geological Survey are available over the counter at the following Geological Survey Public Inquiries Offices, all of which are authorized agents of the Superintendent of Documents:

- WASHINGTON, D.C.--Main Interior Bldg., 2600 corridor, 18 th and C Sts., NW.

- DENVER, Colorado--Federal Bldg., Rm. 169, 1961 Stout St.

- LOS ANGELES, California--Federal Bldg., Rm. 7638, 300 N. Los Angeles St.

- MENLO PARK, California--Bldg. 3 (Stop 533), Rm. 3128, 345 Middlefield Rd.

- RESTON, Virginia--503 National Center, Rm. 1C402, 12201 Sunrise Valley Dr.

- SALT LAKE CITY, Utah--Federal Bldg., Rm. 8105, 125 South State St.

- SAN FRANCISCO, California--Customhouse, Rm. 504, 555 Battery St.

- SPOKANE, Washington--U.S. Courthouse, Rm. 678, West 920 Riverside Ave..

- ANCHORAGE, Alaska--Rm. 101, 4230 University Dr.

- ANCHORAGE, Alaska--Federal Bldg, Rm. E-146, 701 C St.

\section{Maps}

Maps may be purchased over the counter at the U.S. Geological Survey offices where books are sold (all addresses in above list) and at the following Geological Survey offices:

- ROLLA, Missouri--1400 Independence Rd.

- DENVER, Colorado--Map Distribution, Bldg. 810, Federal Center

- FAIRBANKS, Alaska--New Federal Bldg., 101 Twelfth Ave. 


\section{Chloride Flux and Surface Water Discharge out of Yellowstone National Park, 1982-1989}

\section{By DANIEL R. NORTON and IRVING FRIEDMAN}

Tabulation of discharge, chloride concentration and chloride flux for the rivers and streams yields

information related to heat flux from the Park 


\section{U.S. DEPARTMENT OF THE INTERIOR}

MANUEL LUJAN, JR., Secretary

U.S. GEOLOGICAL SURVEY

Dallas L. Peck, Director

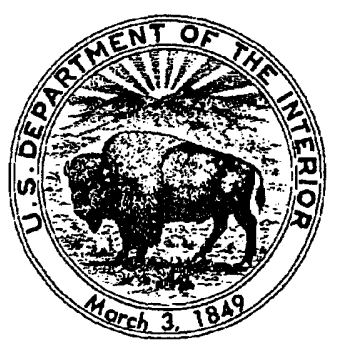

Any use of trade, product, or firm names in this publication is for descriptive purposes only and does not imply endorsement by the U.S. Government.

For sale by the

Books and Open-File Reports Section

U.S. Geological Survey

Federal Center

Box 25425

Denver, CO 80225

\section{Library of Congress Cataloging-in-Publication Data}

Norton, Daniel R.

Chloride flux and surface water discharge out of Yellowstone National Park, 1982-1989 : tabulation of discharge, chloride concentration, and chloride flux for the rivers and streams yields information related to heat flux from the park / by Daniel R. Norton and Irving Friedman.

p. cm. - (U.S. Geological Survey bulletin ; 1959)

Includes bibliographical references.

Supt. of Docs. no.: I 19.16:1959

1. Chlorides. 2. Geochemistry-Yellowstone National Park. 3. Hot springs-Yellowstone National Park. 4. Yellowstone National Park. I. Friedman, Irving, 1920- . II. Title. III. Series.

QE75.B9 no. 1959

[QE516.C5]

$557.3 \mathrm{~s}-\mathrm{dc} 20$

$\left[551.9^{\prime} 09787^{\prime} 5\right]$ 


\section{CONTENTS}

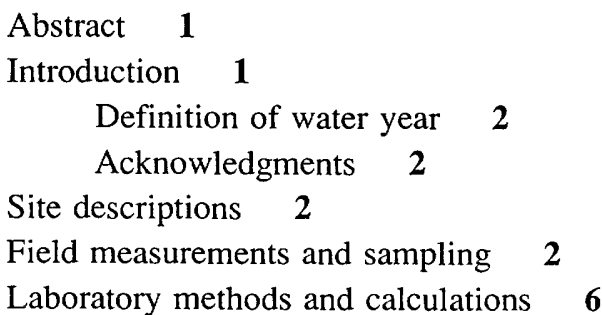

Accuracy 6

Precision 7

Chloride flux 7

Results and discussion $\mathbf{1 0}$

Madison River flux calculations for 1987-1989 $\mathbf{1 0}$

Comparison of our discharge data with those of the long-term records 13

Chloride flux and discharge for individual rivers 13

Total annual discharge and chloride flux from the four major rivers draining the Park 13

Estimated chloride flux in addition to that from the four major rivers

20

Geothermal chloride flux 23

Previous investigations 24

Borah Peak earthquake of October 28, $1983 \quad 24$

Yellowstone fires of $1988 \quad 24$

Use of discharge data to calculate precipitation 25

Conclusions 25

References cited 26

Appendix: Sample-data record showing date and time of collection, chloride concentration of sample, river discharge, and chloride flux for individual collections and for interpolated end-of-month values; all for the Falls, Firehole, Gibbon, Madison, Snake, and Yellowstone Rivers for the water years 1983 through $1989 \quad 27$

\section{FIGURES}

1. Graph of monthly chloride flux of the Falls, Madison, Snake, and Yellowstone Rivers for water year 1983, comparing data reported by Norton and Friedman (1985) with data from the present paper 3

2. Map of Yellowstone National Park region showing stream gauging sites 4

3-16. Graphs showing:

3. Unnormalized mean chloride concentration data of WRD standards plotted against same results normalized against our gravimetrically prepared chloride solutions 7

4. Mean chloride concentration of WRD standards plotted against percent relative standard deviation for both normalized and unnormalized data sets 7 
FIGURES-Continued

3-16. Graphs-Continued

5. Monthly integrated discharge and integrated chloride flux of Madison River compared with the sum of the discharges and of the integrated chloride fluxes of the Firehole and Gibbon Rivers 11

6. Instantaneous discharge and chloride flux for the Madison River $\mathbf{1 2}$

7. Long-term annual discharge of the Falls, Madison, and Yellowstone Rivers 14

8. Instantaneous discharge and chloride flux of the Falls River $\mathbf{1 5}$

9. Instantaneous discharge and chloride flux of the Firehole River $\mathbf{1 6}$

10. Instantaneous discharge and chloride flux of the Gibbon River $\mathbf{1 7}$

11. Instantaneous discharge and chloride flux of the Snake River $\mathbf{1 8}$

12. Instantaneous discharge and chloride flux of the Yellowstone River

13. Minimum discharge of the Yellowstone, Falls, Madison, and Snake Rivers 20

14. Annual chloride flux versus annual discharge of the Falls, Madison, Snake, and Yellowstone Rivers $\mathbf{2 1}$

15. Total annual chloride flux exiting Yellowstone National Park via the Falls, Madison, Snake, and Yellowstone Rivers versus the total annual discharge of these rivers and the total annual discharge and total annual chloride flux of the sum of the four rivers $\mathbf{2 2}$

16. Annual discharges and annual chloride fluxes versus time for the Falls, Madison, Snake, and Yellowstone Rivers 23

\section{TABLES}

1. Gauging site descriptions 5

2. Percentage difference in annual chloride flux calculated using two different sampling protocols $\mathbf{5}$

3. Statistical analysis of chloride concentration data for WRD standards 6

4. Monthly and annual chloride flux and discharge for the six rivers for water years 1983 through $1989 \quad 8$

5. Total chloride flux and river discharge from Yellowstone National Park

6. Calculated precipitation in selected river basins of Yellowstone National Park 25 


\title{
Chloride Flux and Surface Water Discharge out of Yellowstone National Park, 1982-1989
}

\author{
By Daniel R. Norton and Irving Friedman
}

\begin{abstract}
Chloride flux out of Yellowstone National Park (the Park) was calculated by the product of discharge and chloride concentration for the major rivers draining the Park. Additional chloride flux from the western boundary of the Park was also assessed. Improvement in the established chloride determination protocol resulted in an accuracy of 1-3 percent for chloride concentration measurement. The instantaneous river discharges and chloride flux values were integrated to give monthly and annual values for water years 1983-1989. Comparison of the annual discharges for these water years with discharges in the long-term record show that discharges during the years of our study were not exceptional.
\end{abstract}

All the rivers show seasonal variations in discharge and chloride flux that correspond to snowmelt runoff in the spring and to changes in precipitation. Our data show high positive correlations between river discharge and chloride flux. The rivers that drain major thermal areas reveal marked short-time changes in river discharge and chloride flux that are unrelated to seasonal effects. We attribute these changes to variations in thermal activity of the related geyser basins. These variations in thermal activity may be due to tectonic changes triggered by earthquakes or to other events that affect the rate at which magma-generated chloride reaches the surface.

Data generated during the 7-year period of our study show that large annual changes occur in the chloride flux exiting the Park. Most of these changes are attributed to changes in height of the water table caused by variations in precipitation. Because of these large annual changes in chloride flux, long-term records of chloride flux are required to separate changes attributable to climate from those caused by geological events or by the influence of human activity such as energy-resource development.

During the period of our study we observed a decline in the minimum discharge or base flow of all the rivers, which reflects long-term reduced precipitation.

Approximately 94 percent of the chloride flux in waters out of Yellowstone National Park is considered to be of geothermal origin (Norton and Friedman, 1985). Because the geothermal chloride flux is directly related to heat flux, we

Manuscript approved for publication September 10, 1990. determined how much heat flux (in percent of the total from the Park) is contributed by the drainage basins of the following thermal areas of the Park: Firehole River (34 percent); Yellowstone River (30 percent; Snake River (12 percent); Falls River (10 percent); Gibbon River (8 percent); and west side of the Park into the Island Park Geothermal Area (6 percent).

Discharge records of the major rivers draining the Park were used to calculate the annual precipitation for each of the same river drainage basins. This calculation shows that the average annual precipitation over these 7 years of our study was 82 centimeters $(\mathrm{cm})$ for the Falls drainage, $41 \mathrm{~cm}$ for the Madison, $179 \mathrm{~cm}$ for the Snake, and $38 \mathrm{~cm}$ for the Yellowstone.

\section{INTRODUCTION}

Most of the chloride in waters of geothermal origin is magmatic. In Yellowstone National Park, in addition to this magmatic source, minor sources, including human waste, atmospheric precipitation, and weathering of rocks, contribute a maximum of 6 percent to the total chloride flux exiting the Park (Norton and Friedman, 1985). Therefore, a study of variations in this flux from Yellowstone National Park can be used to establish a baseline to determine responses of this measured component to climate changes, earthquakes, and to other tectonic events. In addition, this information can be used to obtain baseline data that will serve in the future to assess adverse impacts on the thermal features of the Park from proposed commercial development of geothermal, oil, and gas resources adjacent to the Park. Inasmuch as the major portion of the chloride exits the Park through four major rivers, these rivers serve as convenient vehicles for measuring most of the chloride flux from the Park.

In a previous paper, Norton and Friedman (1985) discussed chloride flux out of Yellowstone National Park from September 1982 to January 1984. We monitored chloride flux by measuring chloride concentrations and discharges of the four major rivers of the Park. Because this previous study was limited to only one annual cycle, we 
wanted to continue the study of changes in chloride flux and discharge over a longer period of time. In addition to the Falls, Madison, Snake, and Yellowstone Rivers monitored in our earlier study, we added sites on the Firehole and Gibbon Rivers, which drain the major geyser basins of the Park. The data from these two rivers serve to monitor the discharge of thermal waters from these major, deep-seated thermal features.

The current study, a cooperative effort between the U.S. Geological Survey and the National Park Service, includes data from the water years 1983-1989 as well as the data for 1983 previously published by Norton and Friedman (1985). This published chloride flux data was recalculated using improved protocols. On figure 1 we plotted the data as given in the previous paper and the data as recalculated using the current protocols. The differences are minor, except for the Madison River for November through January. We later found the discharge data for the Madison used in our 1985 paper to be in error, so we corrected the data.

\section{Definition of Water Year}

All reported values of annual fluxes are calculated for the water year, which is defined as 12 months beginning with October 1.

\section{Acknowledgments}

The authors wish to acknowledge the contributions made by members of the staffs of the National Park Service and the U.S. Geological Survey (USGS) in this long-term collaborative project between these two agencies. Within the Park Service, John D. Varley, Chief of Research, Yellowstone National Park, was primarily involved in the planning, coordination, and support of this project. Within the Water Resources Division of the USGS, extensive hydrologic support was given by members of the district offices in Montana and Idaho. In Montana we had the support and assistance of Joseph A. Moreland and Ronald R. Shields and their associates. Hydrologists who made valuable contributions to this work are Philip L. Karper, Scott Quimby, Stephen V. Lynn, Norman Midtling, and Andrew R. Skerda. In Idaho we had the support and assistance of Robert W. Harper, Nathan D. Jacobson and their staff. Hydrologists who also contributed to this work are Robert W. Erickson, Owen E. McLaughlin, Stanley G. Landon, and John B. Evans.

We are grateful to the staff of the U.S. Geological Survey's National Water Quality Laboratory for their support and guidance in the automated chloride determinations. Of particular value were the supervisory groups led by James M. Schoen and Harold D. Ardourel. Analysts who contributed to this work are D.M.C.
Wisniewski, Betty McLain, Carl M. Harris, Amy A. Ludtke, and James R. Dobbs. Within the USGS we wish to acknowledge Deanne F. Moore, Deidre J. Scanlon, David C. Guerin, Brian R. Espinoza, Augusta Warden, and Karen E. Slaughter who provided support in sample procurement, data logging, and processing for chemical analysis.

Finally, we acknowledge the dedication of contract collectors for the major rivers and tributaries in this study. Without their able assistance we would not have had the many samples per site required for the integration of chloride flux throughout each of the 7 years of this study. These persons are listed as follows under the names of the river sites for which they provided samples: Snake River samples collected by D.R. McCreight and Cynthia F. Mernin; Falls River samples collected by Viola Lenz; Madison River samples collected by Elizabeth Laden and Karen Bennett; Firehole and Gibbon River samples collected by Karen N. Kennedy, Karen Bennett, Patricia S., Castles, and Shirley A. Wayland; and Yellowstone River samples collected by Mauray M. Miller.

Critical reviews were made by Robert O. Fournier and Yousef K. Kharaka. We thank Diane C. Schnabel for her many suggestions and skillful editing of this paper.

\section{SITE DESCRIPTIONS}

The location of the gauging sites are shown on figure 2 , and the sites are described in table 1. All the sites are official U.S. Geological Survey gauging stations. Sites for discharge measurements were selected on the Snake, Falls, Madison, and Yellowstone Rivers, which are the four major rivers draining the Park. The Madison River was gauged from September 1982 to October 1986. After this station was discontinued, we used the sites on the Firehole and Gibbon Rivers to calculate discharge and chloride flux for the Madison River. The Firehole and Gibbon Rivers were gauged several kilometers $(\mathrm{km})$ above their confluence where the Madison River originates. The gauging site on the Madison River was $24 \mathrm{~km}$ from this confluence. For 22 months all three rivers (Madison, Firehole, and Gibbon) were monitored, which allowed us to compare the discharge and chloride flux from the Madison River with the sum of the values for the other two rivers. This relationship will be discussed in a later section.

Water sampling sites were located near the gauging sites with the exception of the one on the Yellowstone River. To avoid chloride input from La Duke Hot Spring, $3.2 \mathrm{~km}$ upstream from the gauging site, this water sampling site was located about $1 \mathrm{~km}$ upstream from the hot spring.

\section{FIELD MEASUREMENTS AND SAMPLING}

Discharge measurements were made by the U.S. Geological Survey using standard hydrologic methods and 

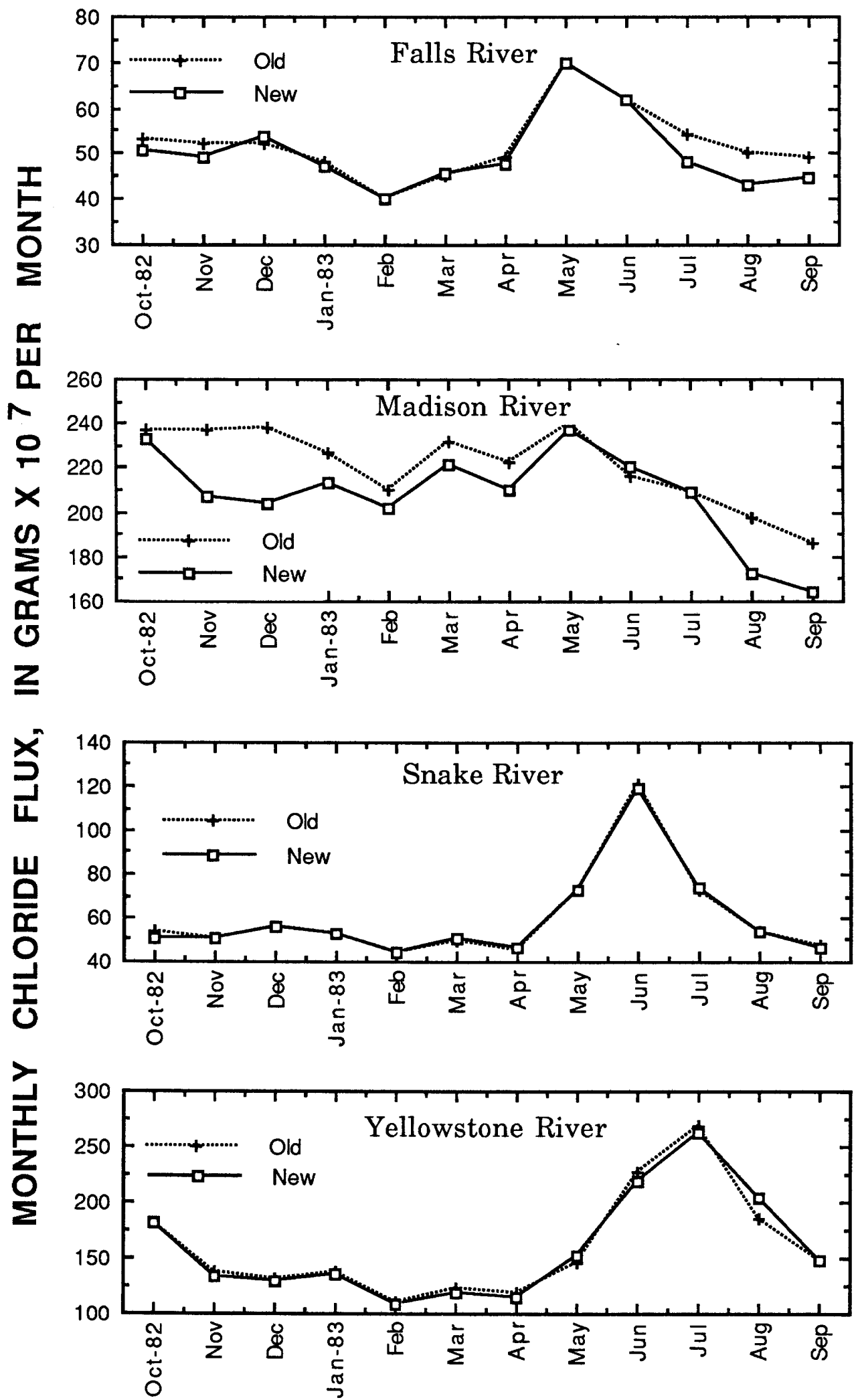

\section{MONTH}

Figure 1. Graph of the monthly integrated chloride flux of the Falls, Madison, Snake, and Yellowstone Rivers for water year 1983. Data reported by Norton and Friedman (1985) (dotted line) are compared with data given in the present paper (solid line). 


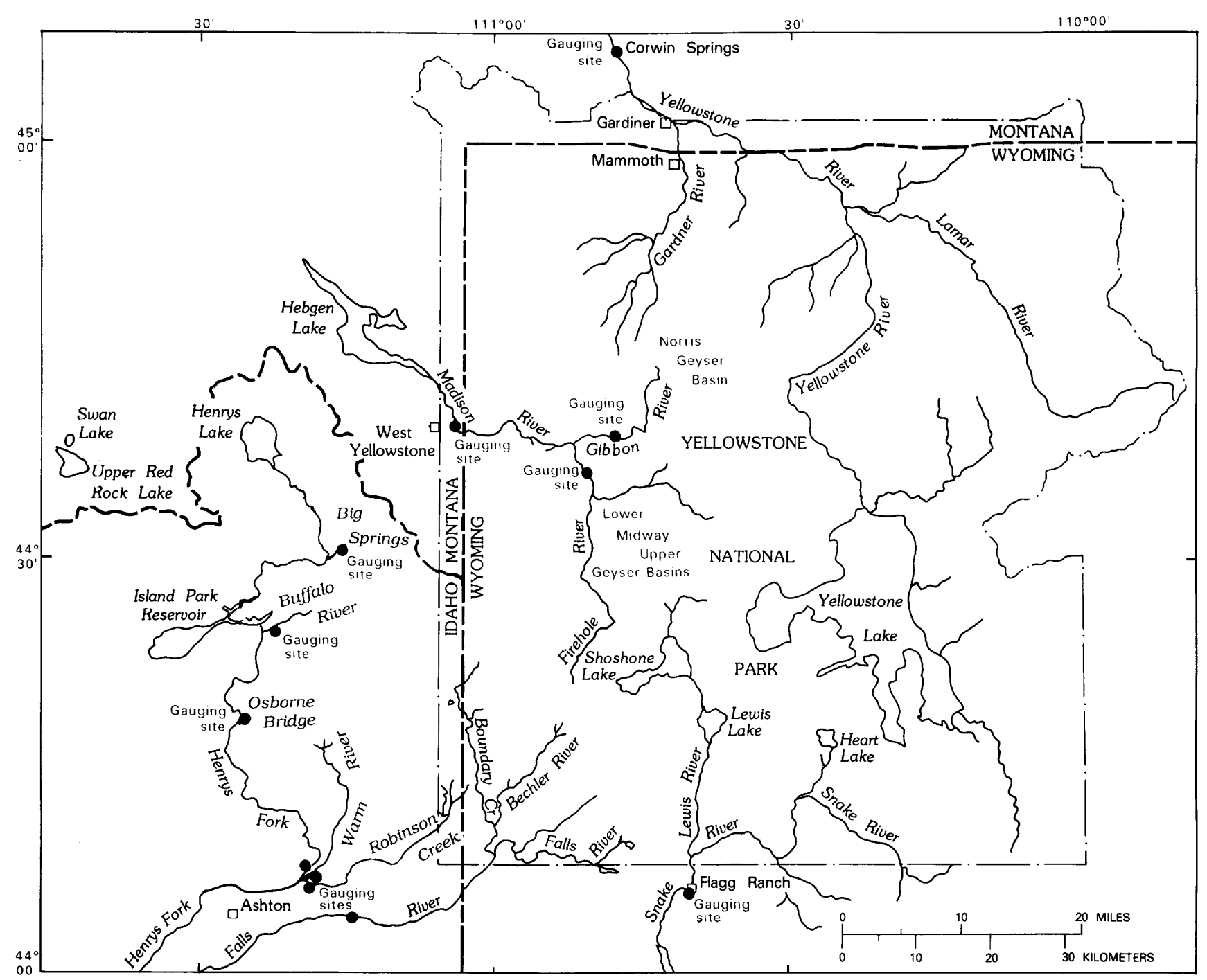

Figure 2. Map of Yellowstone National Park region in Montana, Idaho, and Wyoming, showing the stream gauging sites discussed in this paper.

automated recorders. The discharge data reported in this work were stated by the hydrologists who made the measurements to have an accuracy of 5 percent.

Water samples for chloride determination were withdrawn from the river banks using $50-\mathrm{mL}$ (milliliter) plastic syringes and filtered on site through membrane filters into plastic bottles. The samples were submitted to the U.S. Geological Survey's National Water Quality Laboratory in Denver for analysis. Our tests showed that, for the chloride determination, the samples did not have to be filtered through the standard 0.45-micrometer filters. We used 5-micrometer filters to facilitate the operation.

Our schedule for water sampling of the rivers was monthly for January, February, November, and December; bimonthly for March, April, September, and October; and weekly for May, June, July, and August. This schedule of 28 samples allowed for greater accuracy of the reported data during periods of high runoff in the spring and summer. In contrast, the standard water sampling protocol used by the U.S. Geological Survey is to collect a sample at each site every 6 weeks. Using data from these two different sampling protocols, we calculated the annual chloride flux for 1985 and 1986 for the four rivers draining the Park, as well as the total flux out of the Park, which is the sum of the flux from the Falls, Madison, Snake, and Yellowstone Rivers. The data, given in table 2 , show that the flux calculated for individual rivers by the two protocols differs by as much as 12 percent, whereas the total flux out of the Park differed by 7 percent. Obviously the discrepancy depends upon the specific dates of sampling as related to the timing of snowmelt runoff. In view of these results, we chose a sampling schedule that allowed for increased sampling during the period of high discharge. To our 28 samples per year for each site, we incorporated the 9 
Table 1. Gauging site descriptions

[USGS, U.S. Geological Survey; $\mathrm{km}^{2}$, square kilometer. All topographic maps are USGS 15-minute quadrangle maps]

\begin{tabular}{|c|c|c|c|}
\hline $\begin{array}{l}\text { USGS } \\
\text { Station No. }\end{array}$ & Site name and location & Topographic map & $\begin{array}{l}\text { Drainage } \\
\text { area, }\left(\mathrm{km}^{2}\right)\end{array}$ \\
\hline 13047500 & $\begin{array}{l}\text { Falls River near Squirrel, Idaho, } \\
14.0 \mathrm{~km} \text { from southwest corner of } \\
\text { Yellowstone National Park. }\end{array}$ & $\begin{array}{l}\text { Warm River Butte, } \\
\text { Idaho-Wyo. }\end{array}$ & 909 \\
\hline 06036905 & $\begin{array}{l}\text { Firehole River, } 4.2 \mathrm{~km} \text { upstream } \\
\text { from Madison Junction. }\end{array}$ & Madison Junction, Wyo. & 730 \\
\hline 06037000 & $\begin{array}{l}\text { Gibbon River, } 6.4 \mathrm{~km} \text { upstream } \\
\text { from Madison Junction. }\end{array}$ & Madison Junction, Wyo. & 306 \\
\hline 06037500 & $\begin{array}{l}\text { Madison River at gauging site } \\
\text { shown on map near Riverside. }\end{array}$ & $\begin{array}{l}\text { West Yellowstone, } \\
\text { Mont.-Wyo.-Idaho. }\end{array}$ & 1088 \\
\hline 13010200 & $\begin{array}{l}\text { Snake River near Flagg Ranch, } \\
\text { Wyo., } 3.7 \mathrm{~km} \text { south of Snake River } \\
\text { Ranger Sta., at bridge on U.S. } 287 .\end{array}$ & $\begin{array}{l}\text { Huckleberry Mountain, } \\
\text { Wyo. }\end{array}$ & 405 \\
\hline 06191500 & $\begin{array}{l}\text { Yellowstone River near Corwin } \\
\text { Springs, Mont., at gauging site } \\
\text { shown on map. }\end{array}$ & Miner, Mont.-Wyo. & 6793 \\
\hline
\end{tabular}

Table 2. Percentage difference in annual chloride flux calculated using two different sampling protocols

\begin{tabular}{cccccc}
\hline & $\begin{array}{c}\text { Falls } \\
\text { River }\end{array}$ & $\begin{array}{c}\text { Madison } \\
\text { River }\end{array}$ & $\begin{array}{c}\text { Snake } \\
\text { River }\end{array}$ & $\begin{array}{c}\text { Yellowstone } \\
\text { River }\end{array}$ & $\begin{array}{c}\text { Total, } \\
\text { sum of four rivers }\end{array}$ \\
\hline 1985 & 9 & 5 & -10 & -4 & -11 \\
1986 & -1 & -2 & -12 & -7 & 1 \\
\hline
\end{tabular}

Percent difference $=\frac{(\text { WRD sampling protocol data minus this paper protocol) }}{\text { this paper protocol }} \times 100$

samples per year collected by the USGS, resulting in the analysis of 37 samples per site per year. In addition to the improved accuracy occasioned by our sampling protocol, the increased accuracy of our chloride analyses, as discussed next, adds to the overall accuracy of the calculated chloride flux values.
About 5 percent of the flow of Falls River is diverted upstream from the gauging site at Squirrel, Idaho, for irrigation. We added the measured flow from the Marysville Diversion Canal to all the discharge measurements made at Squirrel in order to determine the true discharge of the Falls River. 
Table 3. Statistical analysis of chloride concentration data for WRD standards

[ppm, parts per million; \%, percent]

\begin{tabular}{lcccc}
\hline $\begin{array}{l}\text { WRD Sample } \\
\text { No. }\end{array}$ & $\begin{array}{c}\text { Number of } \\
\text { analyses }\end{array}$ & $\begin{array}{c}\text { Mean value } \\
(\mathrm{ppm})\end{array}$ & $\begin{array}{c}\text { Standard } \\
\text { deviation }\end{array}$ & $\begin{array}{c}\text { \% Standard } \\
\text { deviation }\end{array}$ \\
\hline 62 & 31 & 8.27 & 0.160 & 1.9 \\
62, normalized* & 31 & 8.24 & 0.405 & 4.9 \\
M6 & 23 & 12.9 & 0.454 & 3.5 \\
M6, normalized & 23 & 13.5 & 0.369 & 2.7 \\
76 & 52 & 25.6 & & 2.6 \\
76, normalized & 52 & 25.5 & 0.655 & 2.9 \\
68 & 57 & 31.0 & 0.727 & 2.1 \\
68, normalized & 57 & 30.9 & 0.656 & 2.6 \\
M86 & 43 & 43.9 & 0.795 & 2.5 \\
M86, normalized & 43 & 44.1 & 1.10 & 1.9 \\
84 & 49 & 50.1 & 0.835 & 1.3 \\
84, normalized & 49 & 50.0 & 0.664 & 1.5 \\
M94 & & & 0.750 & 2.3 \\
M94, normalized & 10 & 65.7 & 1.52 & 0.8 \\
M100 & 10 & 65.2 & 0.524 & 1.3 \\
M100, normalized & 11 & 80.6 & 1.06 & 1.5 \\
\hline
\end{tabular}

* "Normalized" refers to analytical values normalized to a series of GD standards whose chloride concentration values bracketed the WRD values.

\section{LABORATORY METHODS AND CALCULATIONS}

The chloride determinations were made by a modification of the thiocyanate-spectrophotometric method of Skougstad and others (1979) in which the discrete sample analyzer was replaced by an automated segmented sample analyzer. To increase the accuracy of the method, we introduced our own chloride standard solutions, referred to herein as GD standards, between every 10 to 15 samples. We then normalized the laboratory results against these standards, which were prepared gravimetrically from pure $\mathrm{NaCl}$.

In addition to the GD standards, the laboratory routinely introduced their reference samples, referred to herein as WRD standards, at the same frequency as our standards. In order to evaluate the accuracy and precision of the chloride determinations, we made use of the chloride values for the WRD standards as determined for each set of samples. The same set of WRD standards were run repeatedly for 3 years and permitted us to accumulate 23-57 analyses for these standards. Statistical analysis of the results is given in table 3 . The results of these comparisons are presented on figure 3 and 4.

\section{Accuracy}

We observed that the values obtained by the WRD laboratory for the GD $20.0 \mathrm{ppm}$ (parts per million) standard were always less than $20.0 \mathrm{ppm}$ and had a mean value of $18.8 \mathrm{ppm}$. Values on other GD standards, ranging from 10 to $120 \mathrm{ppm}$, gave satisfactory agreement. We attribute this discrepancy to nonlinear response of the instrument in the 20-ppm concentration range.

Figure 3 is a plot of the mean chloride values of the WRD standards normalized against the GD standards that were run concurrently and plotted against the mean of the unnormalized (raw) values reported by the laboratory. Note 
that the slope and intercept of the linear least-squares solution to the plotted data are not 1.0 and zero, which indicates that normalization of the laboratory values to our GD standards will improve the accuracy of the calculated results.

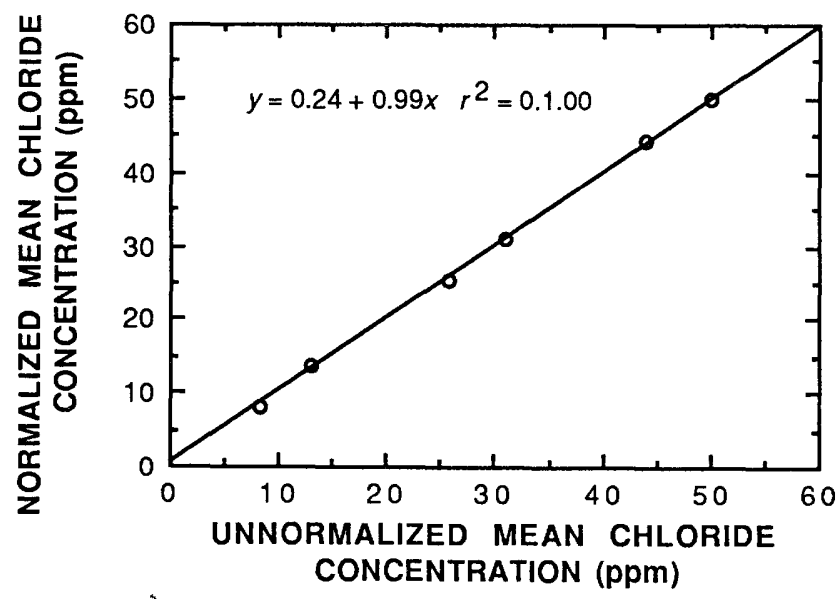

Figure 3. Graphs of the unnormalized mean chloride concentration in parts per million (ppm) of the WRD water standards plotted against the same results normalized against our gravimetrically prepared chloride solutions. $y$, normalized mean chloride concentration; $x$, unnormalized mean chloride concentration; $r^{2}$, correlation coefficient squared.

\section{Precision}

Figure 4 is a plot of the percent relative standard deviation versus the mean values for the WRD standards. The data are shown for both the normalized and unnormalized data sets. This figure and the indicated $r^{2}$ values show that normalization improves the precision of the data. $\left(r^{2}=\right.$ correlation coefficient squared).

The automated chloride analysis apparatus has a digital readout that limits the precision. The results give precisions that vary with chloride concentration from about 1 percent relative standard deviation for chloride concentrations greater than $50 \mathrm{ppm}$, to 3 percent relative standard deviation for concentrations less than $10 \mathrm{ppm}$.

\section{Chloride Flux}

Instantaneous chloride fluxes, shown in the appendix, were calculated by multiplying the chloride concentration of the sample by the river discharge recorded at the time of collection. Monthly integrations were made by first calculating the end-of-month values of discharge and chloride concentration by linear interpolation, and then integrating between each recorded or calculated value. Integrations were done for both monthly and annual periods. The results are given in tables 4 and 5 .

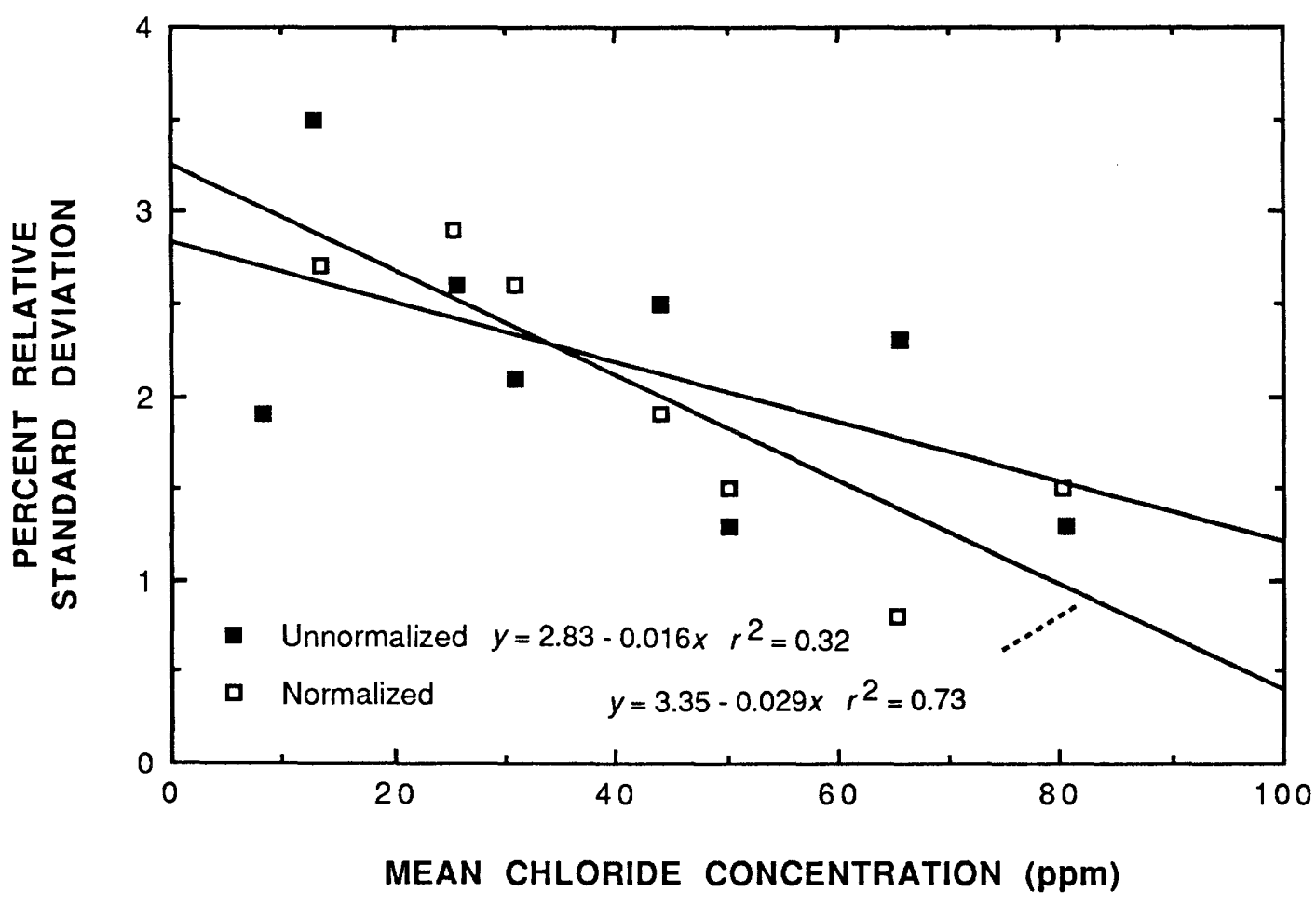

Figure 4. Graph of mean chloride concentration in parts per million (ppm) of the WRD water standards versus percent relative standard deviation determined for both normalized and unnormalized data sets. $y$, percent relative standard deviation; $x$, mean chloride concentration; $r^{2}$, correlation coefficient squared. 
Table 4. Monthly and annual chloride (Cl) flux and discharge (Disch.) for water years 1983 through 1989

[Chloride in grams $\times 10^{7}$; discharge in cubic meters $\times 10^{7}$; - indicates no data]

\section{Falls River}

\begin{tabular}{|c|c|c|c|c|c|c|c|c|c|c|c|c|c|c|}
\hline & \multicolumn{2}{|c|}{1983} & \multicolumn{2}{|c|}{1984} & \multicolumn{2}{|c|}{1985} & \multicolumn{2}{|c|}{1986} & \multicolumn{2}{|c|}{1987} & \multicolumn{2}{|c|}{1988} & \multicolumn{2}{|c|}{1989} \\
\hline & $\mathrm{Cl}$ & Disch. & Cl & Disch. & $\mathrm{Cl}$ & Disch. & Cl & Disch. & $\mathrm{Cl}$ & Disch. & Cl & Disch. & $\mathrm{Cl}$ & Disch. \\
\hline $\begin{array}{l}\text { October } \\
\text { November } \\
\text { December } \\
\text { February } \\
\text { March } \\
\text { April } \\
\text { May } \\
\text { June } \\
\text { July } \\
\text { August } \\
\text { September }\end{array}$ & $\begin{array}{l}50.7 \\
49.3 \\
53.6 \\
39.9 \\
45.5 \\
47.8 \\
70.0 \\
61.8 \\
48.2 \\
42.9 \\
44.5\end{array}$ & $\begin{array}{l}5.17 \\
4.89 \\
4.48 \\
3.14 \\
3.38 \\
4.25 \\
13.0 \\
19.3 \\
10.4 \\
5.52 \\
5.05\end{array}$ & $\begin{array}{l}59.8 \\
60.9 \\
55.6 \\
42.7 \\
42.4 \\
42.3 \\
70.4 \\
71.2 \\
51.0 \\
45.5 \\
48.5\end{array}$ & $\begin{array}{l}6.56 \\
7.50 \\
5.25 \\
3.65 \\
3.61 \\
4.98 \\
20.2 \\
23.7 \\
12.8 \\
6.46 \\
5.57\end{array}$ & $\begin{array}{l}43.5 \\
45.3 \\
45.1 \\
47.0 \\
46.1 \\
65.3 \\
76.3 \\
61.7 \\
57.8 \\
48.2 \\
51.0\end{array}$ & $\begin{array}{l}4.412 \\
4.05 \\
3.87 \\
3.68 \\
3.59 \\
6.54 \\
16.9 \\
15.0 \\
6.90 \\
4.86 \\
4.78\end{array}$ & $\begin{array}{l}47.8 \\
44.9 \\
44.0 \\
40.1 \\
\mathbf{5 1 . 9} \\
\mathbf{6 3 . 9} \\
\mathbf{7 2 . 1} \\
\mathbf{6 8 . 1} \\
\mathbf{5 5 . 4} \\
\mathbf{5 3 . 0} \\
\mathbf{5 0 . 1}\end{array}$ & $\begin{array}{l}4.21 \\
3.81 \\
3.31 \\
3.09 \\
4.53 \\
8.38 \\
14.3 \\
25.4 \\
9.68 \\
6.37 \\
5.36\end{array}$ & $\begin{array}{l}49.7 \\
48.3 \\
46.7 \\
40.8 \\
46.3 \\
58.3 \\
67.7 \\
49.4 \\
41.7 \\
3.07 \\
33.9\end{array}$ & $\begin{array}{l}4.61 \\
4.00 \\
3.54 \\
3.02 \\
3.31 \\
6.79 \\
12.4 \\
5.40 \\
4.00 \\
3.07 \\
2.43\end{array}$ & $\begin{array}{c}32.8 \\
33.3 \\
37.9 \\
35 \\
36.3 \\
60.7 \\
69.4 \\
46.8 \\
43.8 \\
3.32 \\
36.4\end{array}$ & $\begin{array}{l}2.27 \\
8.87 \\
2.40 \\
2.18 \\
2.22 \\
5.37 \\
12.7 \\
8.78 \\
4.77 \\
3.32 \\
2.93\end{array}$ & $\begin{array}{l}38.2 \\
39.3 \\
40.1 \\
38.1 \\
40.6 \\
52.8 \\
77.8 \\
57.7 \\
44.7 \\
42.6 \\
42.1\end{array}$ & $\begin{array}{c}2.86 \\
2.67 \\
2.41 \\
2.22 \\
2.53 \\
4.53 \\
17.8 \\
16.39 \\
6.29 \\
4.57 \\
4.00\end{array}$ \\
\hline Water year & 601.3 & 82.36 & 638.6 & 104.7 & 629.0 & 78.18 & 635.7 & 91.85 & 000.4 & 55.94 & 509.5 & 58.33 & 553.8 & 68.86 \\
\hline
\end{tabular}

Firehole River

\begin{tabular}{|c|c|c|c|c|c|c|c|c|c|c|c|c|c|c|}
\hline & \multicolumn{2}{|c|}{1983} & \multicolumn{2}{|c|}{1984} & \multicolumn{2}{|c|}{1988} & \multicolumn{2}{|c|}{1989} & \multicolumn{2}{|c|}{1987} & \multicolumn{2}{|c|}{1988} & $\mathrm{Cl}^{10}$ & $\begin{array}{l}989 \\
\text { Disch. }\end{array}$ \\
\hline $\begin{array}{l}\text { October } \\
\text { November } \\
\text { December } \\
\text { January } \\
\text { February } \\
\text { March } \\
\text { April } \\
\text { May } \\
\text { June } \\
\text { July } \\
\text { August } \\
\text { September }\end{array}$ & $\begin{array}{l}- \\
- \\
- \\
- \\
- \\
- \\
- \\
- \\
- \\
- \\
- \\
-\end{array}$ & $\begin{array}{l}- \\
- \\
- \\
- \\
- \\
- \\
- \\
- \\
- \\
-\end{array}$ & $\begin{array}{l}170 \\
156 \\
153 \\
150 \\
140 \\
157 \\
151 \\
161 \\
154 \\
145 \\
146 \\
145\end{array}$ & $\begin{array}{l}2.83 \\
2.55 \\
2.33 \\
2.24 \\
2.01 \\
2.18 \\
2.21 \\
3.74 \\
3.76 \\
2.63 \\
2.45 \\
2.38\end{array}$ & $\begin{array}{l}151 \\
151 \\
152 \\
149 \\
131 \\
151 \\
150 \\
144 \\
136 \\
170 \\
169 \\
151\end{array}$ & $\begin{array}{l}2.42 \\
2.34 \\
2.30 \\
2.23 \\
1.92 \\
2.25 \\
2.97 \\
3.27 \\
3.23 \\
3.34 \\
2.75 \\
2.20\end{array}$ & $\begin{array}{l}156 \\
160 \\
158 \\
160 \\
147 \\
168 \\
187 \\
196 \\
152 \\
153 \\
142 \\
139\end{array}$ & $\begin{array}{l}2.39 \\
2.40 \\
2.33 \\
2.29 \\
2.07 \\
2.42 \\
3.00 \\
6.33 \\
5.66 \\
3.36 \\
2.75 \\
2.65\end{array}$ & $\begin{array}{l}140 \\
147 \\
135 \\
143 \\
133 \\
155 \\
136 \\
153 \\
135 \\
134 \\
133 \\
124\end{array}$ & $\begin{array}{l}2.61 \\
2.41 \\
2.27 \\
2.23 \\
2.01 \\
2.23 \\
2.36 \\
2.36 \\
3.02 \\
2.05 \\
1.97 \\
1.78\end{array}$ & $\begin{array}{l}133 \\
129 \\
139 \\
149 \\
138 \\
143 \\
166 \\
149 \\
129 \\
127 \\
125 \\
124\end{array}$ & $\begin{array}{l}1.67 \\
1.77 \\
1.82 \\
1.89 \\
1.75 \\
1.86 \\
2.42 \\
3.16 \\
2.07 \\
1.68 \\
1.62 \\
1.59\end{array}$ & $\begin{array}{l}139 \\
143 \\
135 \\
134 \\
135 \\
155 \\
156 \\
162 \\
142 \\
143 \\
146 \\
133\end{array}$ & $\begin{array}{l}1.78 \\
1.73 \\
1.63 \\
1.69 \\
1.59 \\
1.82 \\
2.31 \\
3.16 \\
3.17 \\
2.21 \\
2.09 \\
1.87\end{array}$ \\
\hline Water year & - & - & 1829 & 31.29 & 1804 & 31.22 & 1918 & 37.63 & 1668 & 26.87 & 1650 & 23.30 & 1723 & 25.03 \\
\hline
\end{tabular}

Gibbon River

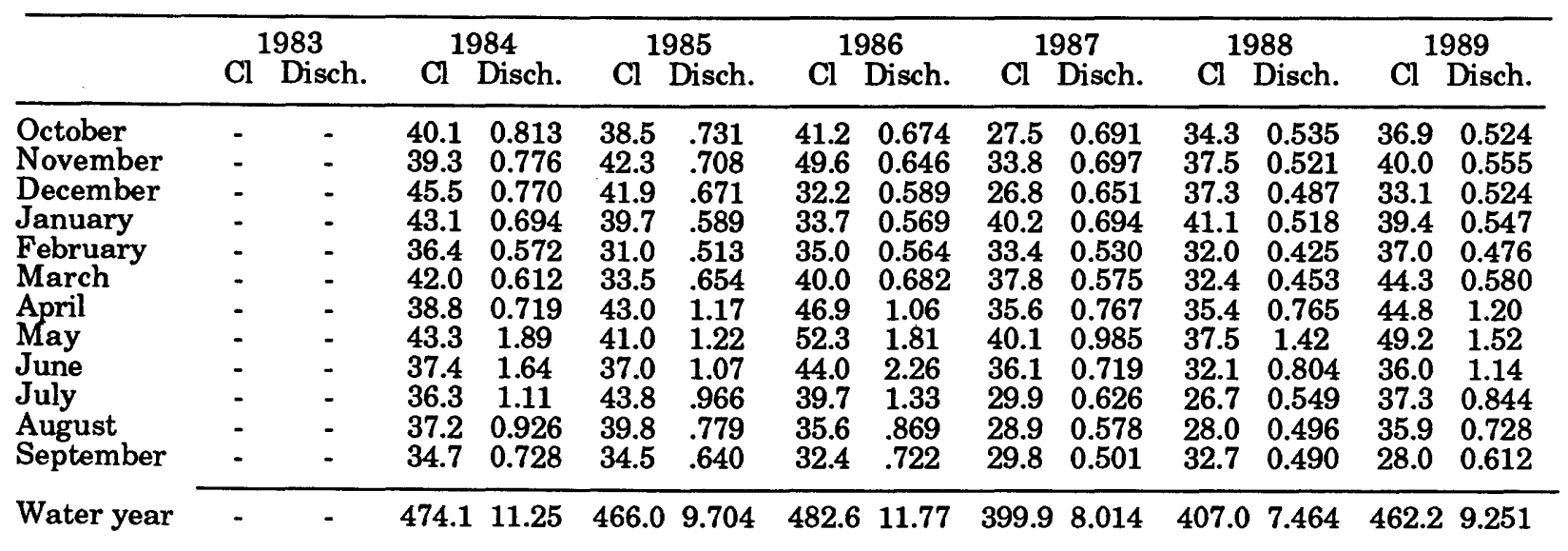


Table 4. Monthly and annual chloride (Cl) flux and discharge (Disch.) for water years 1983 through 1989—Continued

\begin{tabular}{|c|c|c|c|c|c|c|c|c|c|c|c|c|c|c|}
\hline \multicolumn{15}{|c|}{ Madison River } \\
\hline & \multicolumn{2}{|c|}{ Cl $\begin{array}{l}1983 \\
\text { Disch. }\end{array}$} & \multicolumn{2}{|c|}{1984} & \multicolumn{2}{|c|}{1985} & \multicolumn{2}{|c|}{1986} & \multicolumn{2}{|c|}{19871} & \multicolumn{2}{|c|}{$1988^{1}$} & \multicolumn{2}{|c|}{19891} \\
\hline $\begin{array}{l}\text { October } \\
\text { November } \\
\text { December } \\
\text { January } \\
\text { February } \\
\text { March } \\
\text { April } \\
\text { May } \\
\text { June } \\
\text { July } \\
\text { August } \\
\text { September }\end{array}$ & $\begin{array}{l}233 \\
207 \\
203 \\
213 \\
201 \\
221 \\
210 \\
238 \\
221 \\
209 \\
173 \\
165\end{array}$ & $\begin{array}{l}4.19 \\
3.61 \\
3.38 \\
3.38 \\
3.13 \\
3.47 \\
3.34 \\
5.62 \\
7.55 \\
4.96 \\
3.33 \\
3.11\end{array}$ & $\begin{array}{l}190 \\
212 \\
205 \\
199 \\
186 \\
201 \\
191 \\
222 \\
204 \\
176 \\
190 \\
183\end{array}$ & $\begin{array}{l}3.56 \\
3.76 \\
3.49 \\
3.33 \\
2.97 \\
3.12 \\
3.26 \\
7.49 \\
6.34 \\
3.95 \\
3.81 \\
3.42\end{array}$ & $\begin{array}{l}193.3 \\
203.5 \\
206.2 \\
206.5 \\
169.1 \\
202.7 \\
218.2 \\
229.5 \\
187.4 \\
178.3 \\
183.4 \\
183\end{array}$ & $\begin{array}{l}3.49 \\
3.47 \\
3.45 \\
3.34 \\
2.70 \\
3.21 \\
3.97 \\
7.04 \\
4.61 \\
3.41 \\
3.23 \\
3.24\end{array}$ & $\begin{array}{l}204 \\
197 \\
203 \\
197 \\
197 \\
225 \\
233 \\
232 \\
236 \\
197 \\
195 \\
193\end{array}$ & $\begin{array}{l}3.47 \\
3.26 \\
3.34 \\
3.21 \\
3.08 \\
3.79 \\
4.51 \\
7.22 \\
9.94 \\
5.11 \\
4.00 \\
4.01\end{array}$ & $\begin{array}{l}173 \\
187 \\
168 \\
190 \\
172 \\
200 \\
178 \\
200 \\
177 \\
169 \\
168 \\
160\end{array}$ & $\begin{array}{l}3.68 \\
3.47 \\
3.27 \\
3.27 \\
2.84 \\
3.13 \\
3.50 \\
4.48 \\
3.09 \\
2.90 \\
2.80 \\
2.54\end{array}$ & $\begin{array}{l}174 \\
173 \\
182 \\
197 \\
176 \\
182 \\
208 \\
193 \\
167 \\
159 \\
158 \\
163\end{array}$ & $\begin{array}{l}2.46 \\
2.56 \\
2.58 \\
2.69 \\
2.43 \\
2.58 \\
3.56 \\
5.11 \\
3.21 \\
2.49 \\
2.36 \\
2.33\end{array}$ & $\begin{array}{l}174 \\
188 \\
174 \\
180 \\
178 \\
207 \\
208 \\
219 \\
185 \\
187 \\
188 \\
167\end{array}$ & $\begin{array}{l}2.44 \\
2.52 \\
2.41 \\
2.50 \\
2.31 \\
2.68 \\
3.92 \\
5.22 \\
4.81 \\
3.41 \\
3.15 \\
2.77\end{array}$ \\
\hline Water year & 2494 & 49.07 & 2358 & 48.49 & 2358 & 45.17 & 2509 & 55.24 & 2142 & 38.96 & 2131 & 34.36 & 2253 & 38.14 \\
\hline \multicolumn{15}{|c|}{ Snake River } \\
\hline & \multicolumn{2}{|c|}{1983} & \multicolumn{2}{|c|}{1984} & \multicolumn{2}{|c|}{1985} & \multicolumn{2}{|c|}{1986} & \multicolumn{2}{|c|}{1987} & \multicolumn{2}{|c|}{1988} & $\mathrm{Cl}^{19}$ & $\begin{array}{l}989 \\
\text { Disch. }\end{array}$ \\
\hline $\begin{array}{l}\text { October } \\
\text { November } \\
\text { December } \\
\text { January } \\
\text { February } \\
\text { March } \\
\text { April } \\
\text { May } \\
\text { June } \\
\text { July } \\
\text { August } \\
\text { September }\end{array}$ & $\begin{array}{l}50.5 \\
50.8 \\
56.0 \\
52.7 \\
43.7 \\
49.3 \\
45.9 \\
73.5 \\
119 \\
73.6 \\
53.5 \\
58.3\end{array}$ & $\begin{array}{l}3.76 \\
3.47 \\
3.55 \\
3.23 \\
2.66 \\
2.91 \\
2.82 \\
13.5 \\
33.2 \\
12.5 \\
5.05 \\
4.61\end{array}$ & $\begin{array}{l}50.6 \\
47.7 \\
56.4 \\
63.2 \\
48.5 \\
46.7 \\
46.3 \\
78.5 \\
101 \\
66.2 \\
45.4 \\
42.9\end{array}$ & $\begin{array}{l}4.90 \\
5.10 \\
4.51 \\
4.07 \\
3.06 \\
2.82 \\
2.99 \\
16.3 \\
17.6 \\
8.01 \\
4.28 \\
3.37\end{array}$ & $\begin{array}{l}46.1 \\
47.6 \\
47.5 \\
47.3 \\
41.9 \\
49.5 \\
54.8 \\
108 \\
83.2 \\
48.3 \\
43.8 \\
42.6\end{array}$ & $\begin{array}{l}3.10 \\
3.17 \\
3.11 \\
2.99 \\
2.43 \\
2.55 \\
4.12 \\
20.2 \\
15.4 \\
4.75 \\
3.19 \\
2.93\end{array}$ & $\begin{array}{l}45.2 \\
50.7 \\
47.8 \\
46.7 \\
49.9 \\
61.2 \\
60.8 \\
78.4 \\
200.4 \\
71.8 \\
53 \\
47.2\end{array}$ & $\begin{array}{l}2.83 \\
3.31 \\
2.87 \\
2.68 \\
3.21 \\
3.96 \\
5.38 \\
15.5 \\
42.3 \\
10.7 \\
5.01 \\
3.80\end{array}$ & $\begin{array}{l}45.3 \\
50.0 \\
46.8 \\
42.5 \\
43.5 \\
45.9 \\
49.7 \\
67.5 \\
51.2 \\
41.7 \\
34.0 \\
32.7\end{array}$ & $\begin{array}{l}3.31 \\
3.15 \\
2.74 \\
2.41 \\
2.48 \\
2.63 \\
4.42 \\
12.4 \\
6.14 \\
3.47 \\
2.00 \\
1.58\end{array}$ & $\begin{array}{l}30.4 \\
27.9 \\
37.3 \\
43.8 \\
44.7 \\
44.5 \\
56.8 \\
77.1 \\
68.0 \\
35.0 \\
30.7 \\
31.6\end{array}$ & $\begin{array}{l}1.35 \\
1.42 \\
1.83 \\
2.17 \\
2.11 \\
2.09 \\
3.69 \\
14.8 \\
12.8 \\
2.55 \\
1.52 \\
1.31\end{array}$ & $\begin{array}{l}35.3 \\
36.9 \\
43.1 \\
45.6 \\
39.9 \\
47.9 \\
51.0 \\
123.7 \\
94.5 \\
53.2 \\
41.2 \\
32.1\end{array}$ & $\begin{array}{l}1.47 \\
1.56 \\
1.74 \\
2.08 \\
1.88 \\
2.46 \\
4.15 \\
27.6 \\
21.0 \\
5.69 \\
3.06 \\
2.06\end{array}$ \\
\hline Water year & 727.0 & 91.24 & 693.7 & 76.98 & 660.2 & 67.92 & 813.1 & 101.5 & 550.8 & 46.70 & 527.8 & 47.60 & 644.4 & 74.73 \\
\hline \multicolumn{15}{|c|}{ Yellowstone River } \\
\hline & \multicolumn{2}{|c|}{1983.} & \multicolumn{2}{|c|}{1984} & \multicolumn{2}{|c|}{1985} & \multicolumn{2}{|c|}{1986} & \multicolumn{2}{|c|}{1987} & \multicolumn{2}{|c|}{1988} & $\mathrm{Cl}^{15}$ & $\begin{array}{l}989 \\
\text { Disch. }\end{array}$ \\
\hline $\begin{array}{l}\text { October } \\
\text { November } \\
\text { December } \\
\text { January } \\
\text { February } \\
\text { March } \\
\text { April } \\
\text { May } \\
\text { June } \\
\text { July } \\
\text { August } \\
\text { September }\end{array}$ & $\begin{array}{l}182 \\
134 \\
129 \\
135 \\
107 \\
119 \\
115 \\
152 \\
218 \\
262 \\
204 \\
148\end{array}$ & $\begin{array}{l}16.7 \\
10.9 \\
9.24 \\
8.53 \\
7.37 \\
7.75 \\
8.08 \\
23.2 \\
66.1 \\
56.8 \\
27.4 \\
16.2\end{array}$ & $\begin{array}{l}134 \\
146 \\
156 \\
128 \\
109 \\
119 \\
119 \\
157 \\
247 \\
346 \\
201 \\
144\end{array}$ & $\begin{array}{l}15.8 \\
14.3 \\
12.0 \\
9.75 \\
7.96 \\
8.14 \\
9.33 \\
49.5 \\
86.0 \\
62.4 \\
26.1 \\
17.1\end{array}$ & $\begin{array}{l}136 \\
124 \\
120 \\
109 \\
102 \\
102 \\
110 \\
171 \\
274 \\
198 \\
160 \\
135\end{array}$ & $\begin{array}{l}13.0 \\
10.6 \\
9.04 \\
7.66 \\
6.94 \\
7.77 \\
12.4 \\
45.1 \\
57.0 \\
29.9 \\
18.3 \\
13.8\end{array}$ & $\begin{array}{l}133 \\
124 \\
95.7 \\
99.8 \\
97.3 \\
120 \\
116 \\
187 \\
490 \\
325 \\
226 \\
160\end{array}$ & $\begin{array}{l}11.0 \\
8.76 \\
6.59 \\
6.96 \\
6.88 \\
10.3 \\
15.3 \\
54.4 \\
117 \\
54.5 \\
27.8 \\
18.2\end{array}$ & $\begin{array}{l}141 \\
129 \\
110 \\
104 \\
99.2 \\
109 \\
176 \\
200 \\
196 \\
192 \\
147 \\
112\end{array}$ & $\begin{array}{l}13.4 \\
10.1 \\
7.82 \\
7.35 \\
6.88 \\
7.31 \\
22.7 \\
43.9 \\
34.9 \\
23.8 \\
13.7 \\
8.82\end{array}$ & $\begin{array}{l}98.0 \\
98.1 \\
116 \\
97.4 \\
82.9 \\
93.5 \\
94.6 \\
134 \\
213 \\
183 \\
129 \\
102\end{array}$ & $\begin{array}{l}6.32 \\
5.62 \\
5.43 \\
4.16 \\
3.96 \\
5.33 \\
10.2 \\
37.2 \\
57.9 \\
21.0 \\
11.2 \\
6.84\end{array}$ & $\begin{array}{l}99.1 \\
87.7 \\
94.9 \\
88.3 \\
78.9 \\
84.5 \\
87.7 \\
267 \\
291 \\
283 \\
177 \\
135\end{array}$ & $\begin{array}{l}5.90 \\
5.05 \\
4.92 \\
3.86 \\
3.37 \\
4.63 \\
11.5 \\
79.3 \\
75.9 \\
41.3 \\
19.5 \\
12.5\end{array}$ \\
\hline Water year & 1905 & 258.2 & 2007 & 318.3 & 1741 & 231.5 & 2173 & 337.7 & 1716 & 200.6 & 1441 & 175.27 & 1775 & 267.5 \\
\hline
\end{tabular}

\footnotetext{
1 Chloride flux data for this year calculated by summing values of the Gibbon and Firehole Rivers and multipying by 1.037 (see text).

Discharge data for this year calculated by summing values for the Gibbon and Firehole Rivers and multipying by 1.117 (see text).
} 
Table 5. Total chloride flux and river discharge from Yellowstone National Park

\begin{tabular}{cccc}
\hline \multirow{2}{*}{$\begin{array}{c}\text { Water } \\
\text { year }\end{array}$} & \multicolumn{3}{c}{ Total } \\
\cline { 2 - 4 } & Four rivers $^{1}$ & $\begin{array}{c}\text { Four rivers plus } \\
\text { Island Park sites }\end{array}$ \\
\cline { 2 - 4 } \cline { 3 - 3 } & Flux $^{2}$ & Discharge $^{3}$ & Flux \\
\hline 1983 & 5730 & 4810 & 6100 \\
1984 & 5700 & 5490 & 6000 \\
1985 & 5390 & 4230 & 5700 \\
1986 & 6130 & 5850 & 6500 \\
1987 & 4990 & 3440 & 5300 \\
1988 & 4610 & 3160 & 4900 \\
1989 & 5240 & 4490 & 5600 \\
\hline
\end{tabular}

${ }^{1}$ The totals are the sum of the values for the Falls, Madison, Snake, and Yellowstone Rivers.

2 Chloride flux values are given in grams of chloride per year $\times 10^{7}$.

3 Discharge values are given in cubic meters per year $x 10^{7}$.

${ }^{4}$ Total flux is calculated by multiplying flux values determined by summing the flux from the four rivers and multiplying by 1.06 .

The error assigned to the instantaneous chloride flux calculations is \pm 5.4 percent. This value is derived from the errors of the individual chloride concentration ( $E=2$ percent) and discharge measurements ( $E=5$ percent) as follows, where $E=$ =rror:

$$
\text { Chloride flux error }=\sqrt{E_{\text {Chloride }}^{2}+E_{\text {Discharge }}^{2}}
$$

\section{RESULTS AND DISCUSSION}

\section{Madison River Flux Calculations for 1987-1989}

The Madison River site was monitored for about 4 years from late 1982 through 1986, after which time monitoring was discontinued. Inasmuch as the Firehole and Gibbon Rivers are the major tributaries of the Madison, monitoring sites on the Firehole and Gibbon were established in 1984 and continued through 1989. To compare monthly integrated chloride flux and discharge for the Madison River, as measured at the Madison River gauging site, with values calculated from the sum of the Firehole and Gibbon Rivers, we used data from 1984, 1985, and 1986. In figure 5 we have plotted the monthly integrated discharge and chloride flux for the Madison, as well the sum of values for the Firehole and Gibbon Rivers from the values given in table 4 . The chloride flux for this 3-year period in the Madison River is 3.6 percent greater than that for the sum of the values for the Firehole and Gibbon Rivers. A similar comparison made for discharge showed that discharge was 11.7 percent greater at the Madison River gauging site, which is $24 \mathrm{~km}$ from the confluence of the Firehole and Gibbon Rivers. These increased values of flux and discharge result from additional input to the Madison along this $24-\mathrm{km}$-long drainage basin, as well as additional inputs from the Firehole and Gibbon above their confluence. This effect is particularly pronounced during spring runoff when low-chloride snowmelt water is introduced along this $24-\mathrm{km}$ stretch of the river.

Using this information we corrected the chloride flux and discharge values obtained from the sum of the Firehole and Gibbon Rivers to make them equivalent to that which 


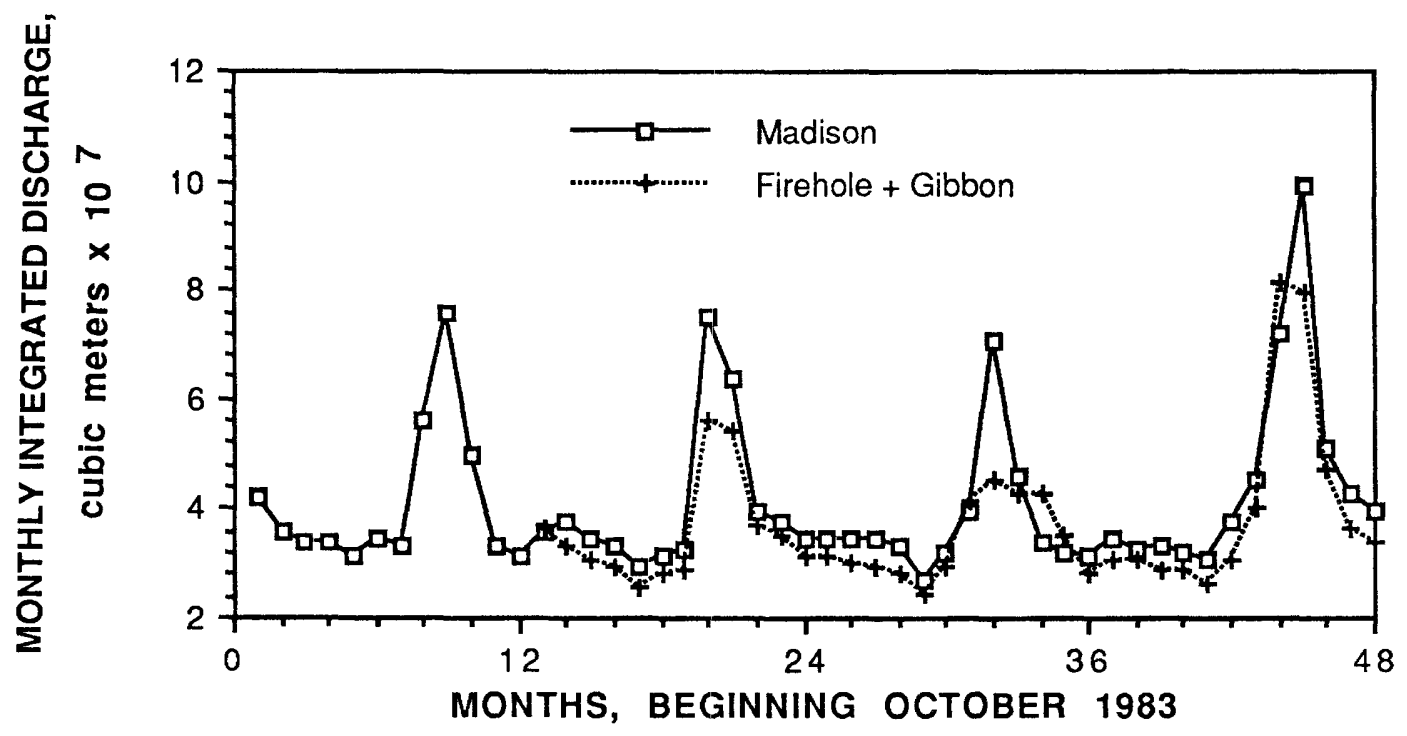

$\boldsymbol{A}$

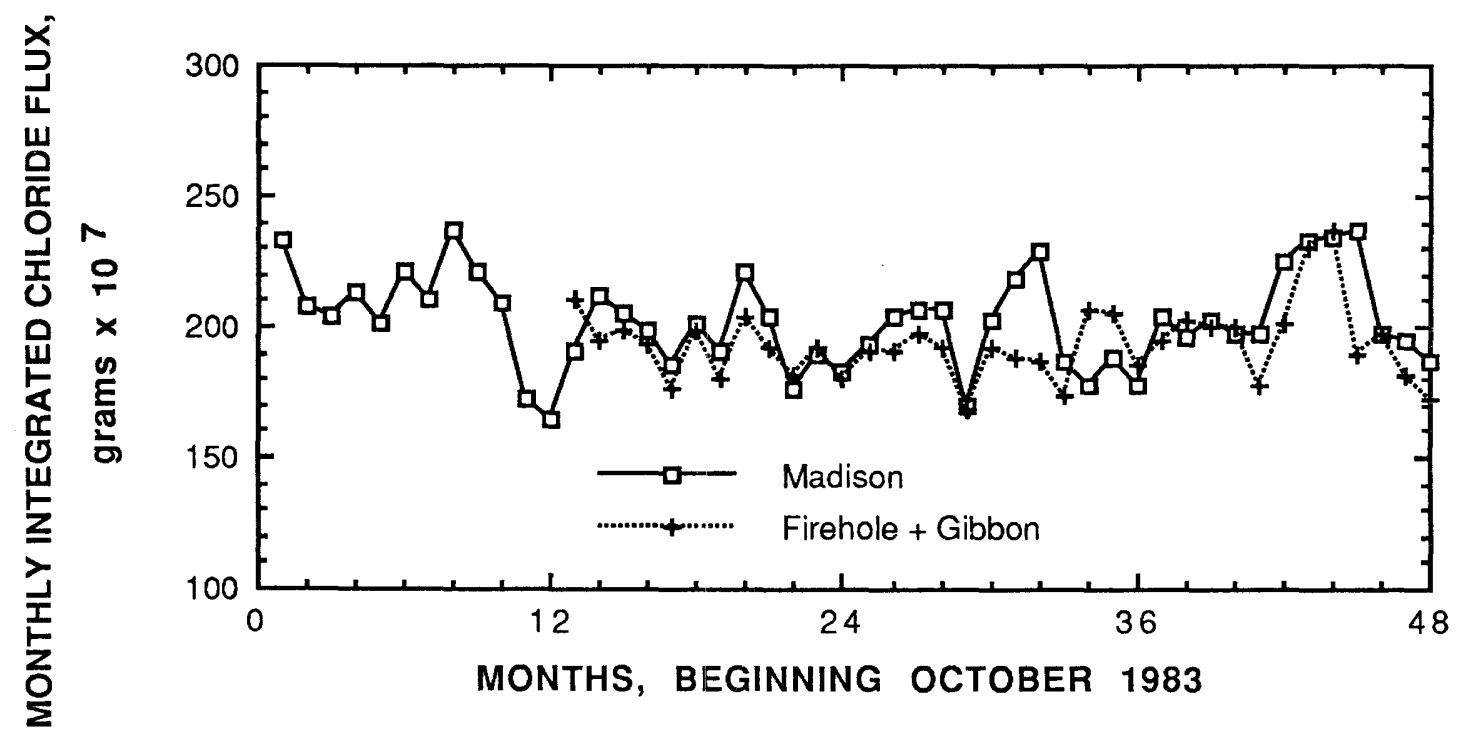

$\boldsymbol{B}$

Figure 5. Graphs of the monthly integrated discharge $(A)$ and monthly integrated chloride flux $(B)^{\circ}$ of the Madison River for 48 months, beginning in October 1983, as well as the sum of the integrated discharges and of the integrated chloride fluxes of the Firehole and Gibbon Rivers for the same time period.

would have been obtained for the Madison River for 1987, 1988, and 1989. The corrections can only be used for the annual fluxes for the Madison River for these 3 years but will distort the instantaneous and monthly flux values because most of the fluxes added along the 24-km stretch of the Madison are added during a short period in the spring, and we are applying uniform corrections throughout the year. For this reason the, uncorrected (sum of the Firehole and Gibbon Rivers) instantaneous values of discharge and chloride flux for the Madison for 1987-89 are plotted in figure 6 , but the corrected annual values are given in tables 4 and 5 . 
Madison River

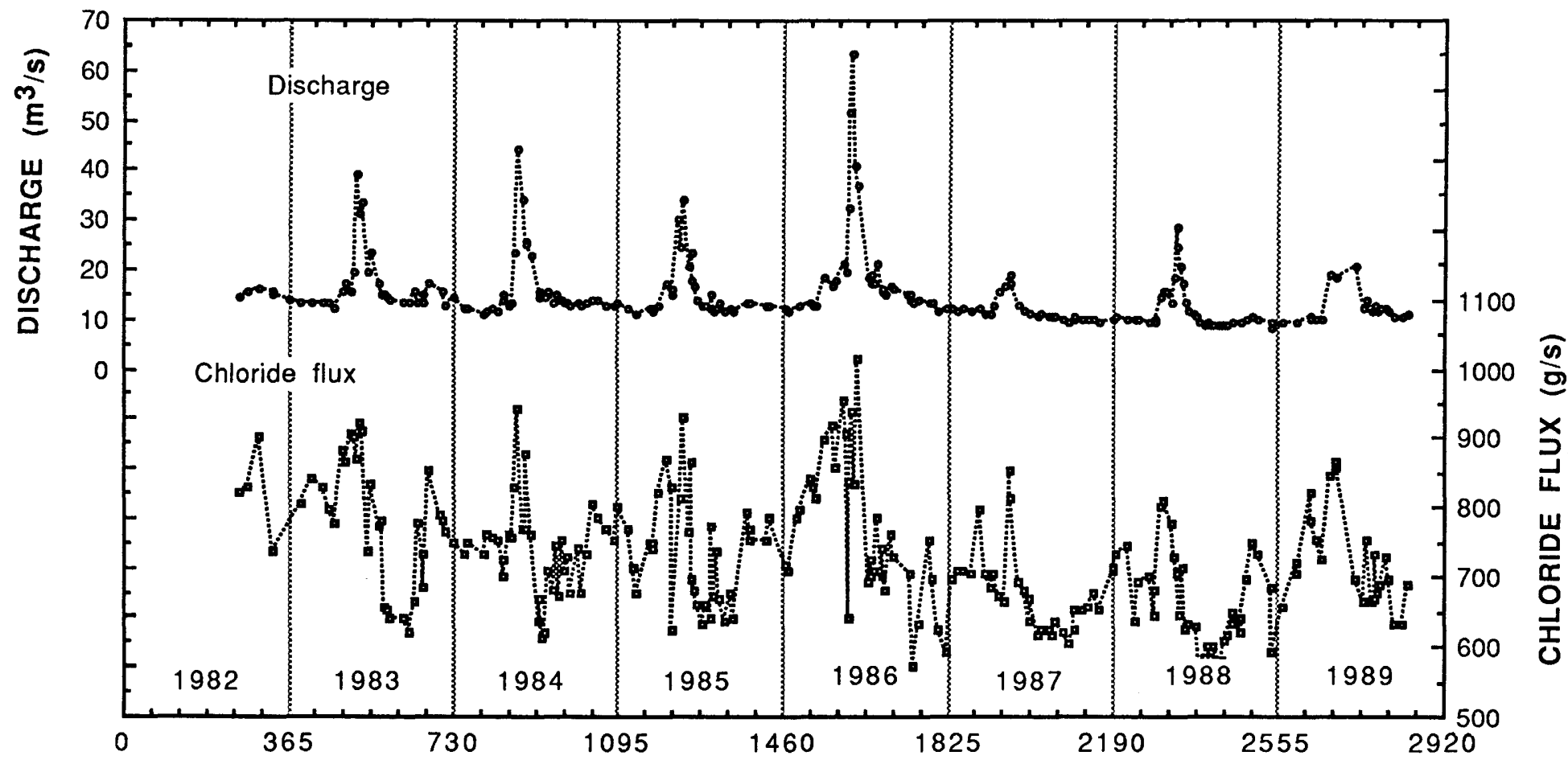

CALENDAR YEAR AND DATE NUMBER

Figure 6. Graphs of the instantaneous discharge in cubic meters per second $\left(\mathrm{m}^{3} / \mathrm{s}\right)$ and the chloride flux in grams per second $(\mathrm{g} / \mathrm{s})$ for the $\mathrm{Madison}$ River. Plotted points are from data given in the appendix. Calendar years are shown. Data for water years 1987, 1988, and 1989 were calculated by adding the measurements made on the Firehole and Gibbon Rivers. No corrections have been made to the data for 1987,1988 , and 1989 to account for the different sampling sites used for these years. 


\section{Comparison of Our Discharge Data with Those of the Long-Term Records}

Figure 7 shows annual discharge for the Falls, Madison, and Yellowstone Rivers during 30 years of record. Data for the Snake River are not available. The longer term average annual discharge is also shown on figure 7 . The years of our study are indicated in the figure and show that the data for these years are not exceptional as compared with data from the long-term record.

Tabulated data for instantaneous measurements including the date and time of collection, discharge, chloride concentration, and chloride flux are given in the appendix. The integrated monthly discharge ${ }^{1}$ and chloride flux calculated from this data are given in table 4 . The discharge and chloride flux of the rivers as a function of time are shown on figures 6 and $8-12$. We included in both the tabulated data and in the figures, data recalculated from that previously published by Norton and Friedman (1985).

\section{Chloride Flux and Discharge for Individual Rivers}

The spring runoff peaks for both discharge and chloride flux are higher relative to base flow values for drainage basins that are not dominated by discharges from major thermal areas. For example, the Yellowstone River typically shows peak discharges as great as 25 times base flow (fig. 12). These peak discharges are much smaller in drainage basins dominated by large thermal areas where snowmelt is continuous during the winter, resulting in spring runoff peaks for the Firehole, Gibbon, and Madison that are only about three times the base flow (figs. 6, 9, and 10 ).

In the Madison River drainage basin, which is dominated by the major thermal areas along the Firehole and Gibbon Rivers, there are variations in instantaneous chloride flux that are random with time. These variations are attributed to changes in the thermal activity in these basins, including eruptions of geysers of large discharge, and variations in overall activity of the thermal springs in the basins.

\footnotetext{
${ }^{1}$ Annual water-year discharge data for the Yellowstone River site were taken from the following references to the published records of the U.S. Geological Survey: Surface water supply of the U.S., 1960-1965; Water resources data for Montana, 1966-1975: Water resources data, Montana, water-years 1976-1989. For the Madison River site, data were taken from Survey records as follows: Surface water supply of the U.S., 1944-1965; Water resources data for Montana, 1966-1975; Water resources data, Montana, water years 1976-1989. For the Falls River site, data were taken from Survey records as follows: Records of surface water of the U.S., 1950-1960; Surface water supply of the U.S., 1961-1970; Water resources data for Idaho, 1971-1974; Water resources data, Idaho, water years 1975-1989.
}

The relationships of instantaneous discharge and chloride flux with time for the Falls, Snake, and Yellowstone Rivers (figs. 8, 11, and 12) are similar. All three rivers show sharp seasonal peaks in discharge related to spring runoff, which are as great as 25 times base flow. In all the rivers. the corresponding chloride flux values show similar peaks that are coincident with discharge peaks.

The base flow, or minimum discharges for the four major rivers draining the Park show a downward trend for the years of our study, as illustrated on figure 13. We believe this trend results from long-term changes in precipitation in this region.

Plots of annual discharge versus annual chloride for each river are given in figure 14 and show a high correlation between discharge and chloride flux, with correlation coefficient $\left(r^{2}\right)$ values between 0.72 and 0.94 . A discussion of this relationship is given in Friedman and Norton (1990). Previous authors (Fournier and others, 1976; D.E. White, oral commun., 1984) have noted similar relationships between instantaneous values of discharge and chloride flux and ascribed these to chloride stored in the soil during the winter and released with the spring runoff. Friedman and Norton (1990) preferred a different interpretation and proposed that a large part of seasonal changes in chloride flux are related to changes in height of the water table, which in turn influences the discharges of chloridecontaining springs.

\section{Total Annual Discharge and Chloride Flux From the Four Major Rivers Draining The Park}

The annual discharge and chloride flux for the sum of the four major rivers draining the Park are shown in table 5 and on figure $15 B$. A graph showing the linear least-squares solution to this data is shown on figure $15 A$. The overall relationship follows that shown on figure 16 for the individual rivers; namely, an increase in both chloride flux and discharge for 1986, a decrease in these values for 1987, 1988 , and a slight recovery in 1989 , compared with the values reported for 1983 and 1984. The discharge and chloride flux have a linear relationship. The increase in chloride flux with discharge is mostly due to the increase in the height of the water table during periods of increased flow, to a lesser extent due to stored chloride, and to only traces of chloride introduced by precipitation, weathering, and human activity. Using only chloride introduced by precipitation to explain these results would require the [Text continues on page 20.] 


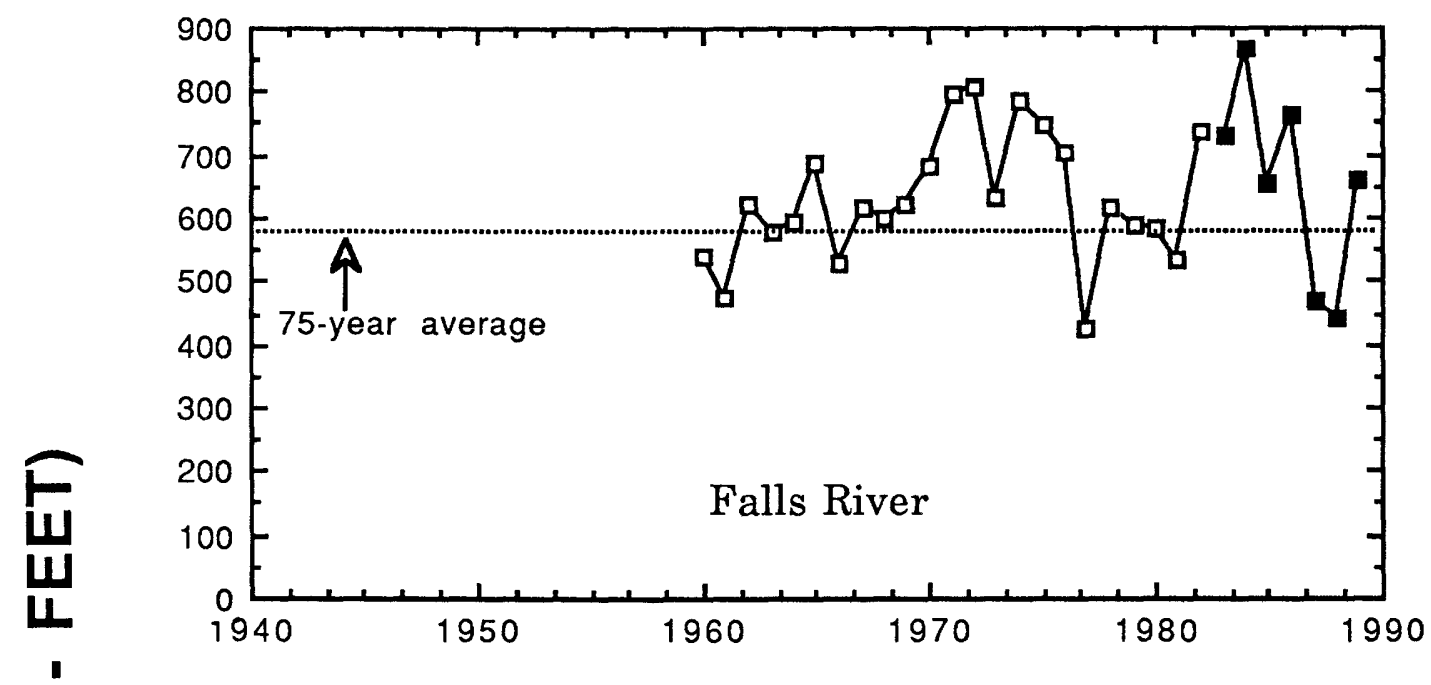

崩

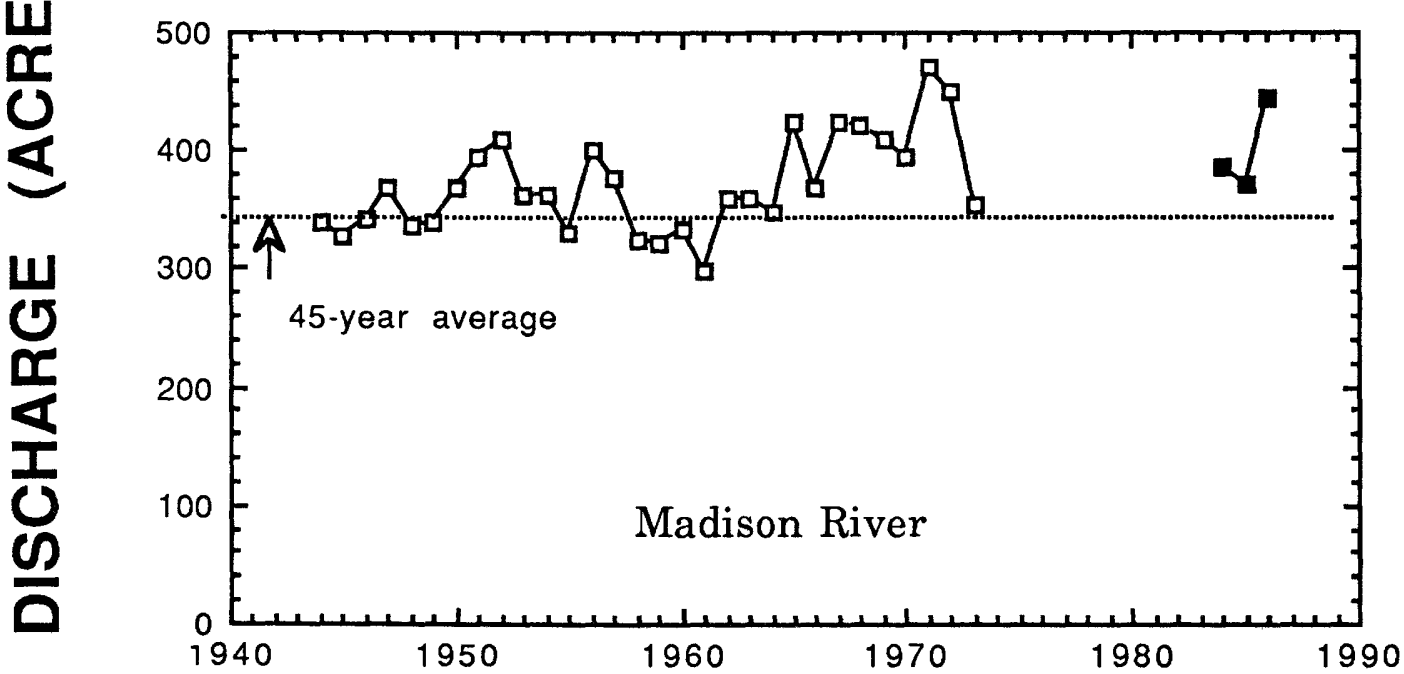

岁

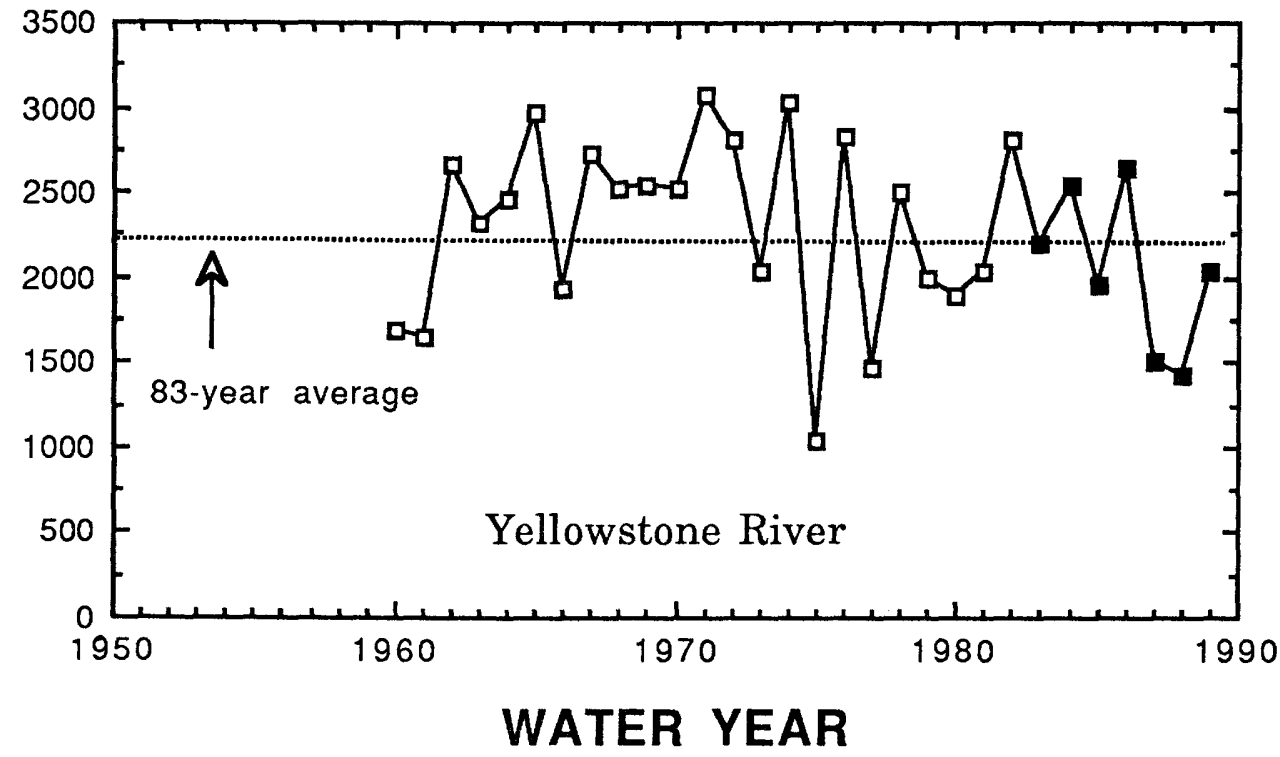

Figure 7. Graphs of the annual discharge in acre-feet as a function of time for the Falls, Madison, and Yellowstone Rivers from data published by the U.S. Geological Survey. The years of our study are shown as solid boxes. The long-term average for each river is shown as a dotted horizontal line. 


\section{Falls River}

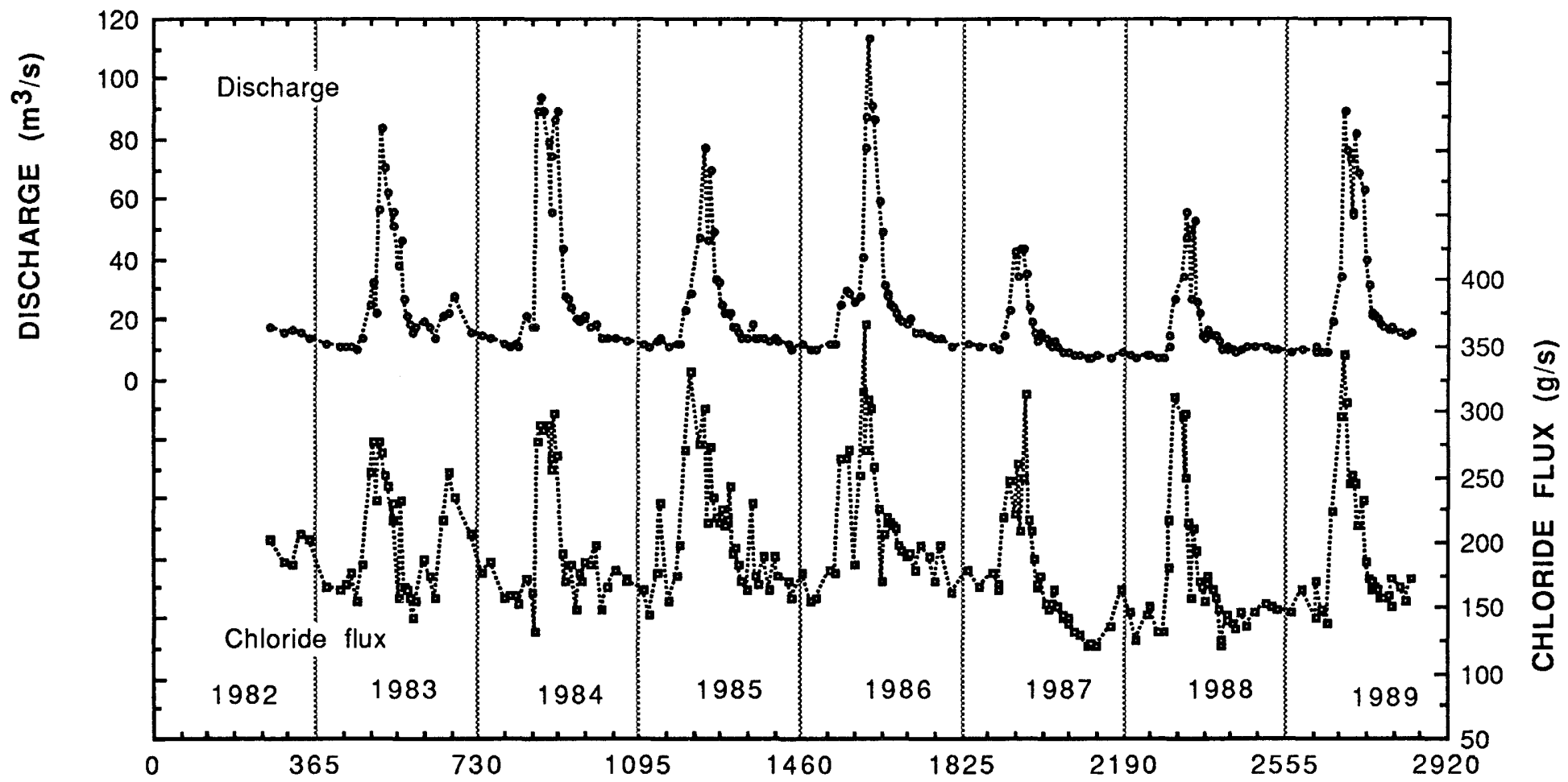

\section{CALENDAR YEAR AND DATE NUMBER}

Figure 8. Graphs of the instantaneous discharge in cubic meters per second $\left(\mathrm{m}^{3} / \mathrm{s}\right)$ and the chloride flux in grams per second $(\mathrm{g} / \mathrm{s})$ for the Falls River. Plotted points are from data given in the appendix. Calendar years are shown. 


\section{Firehole River}

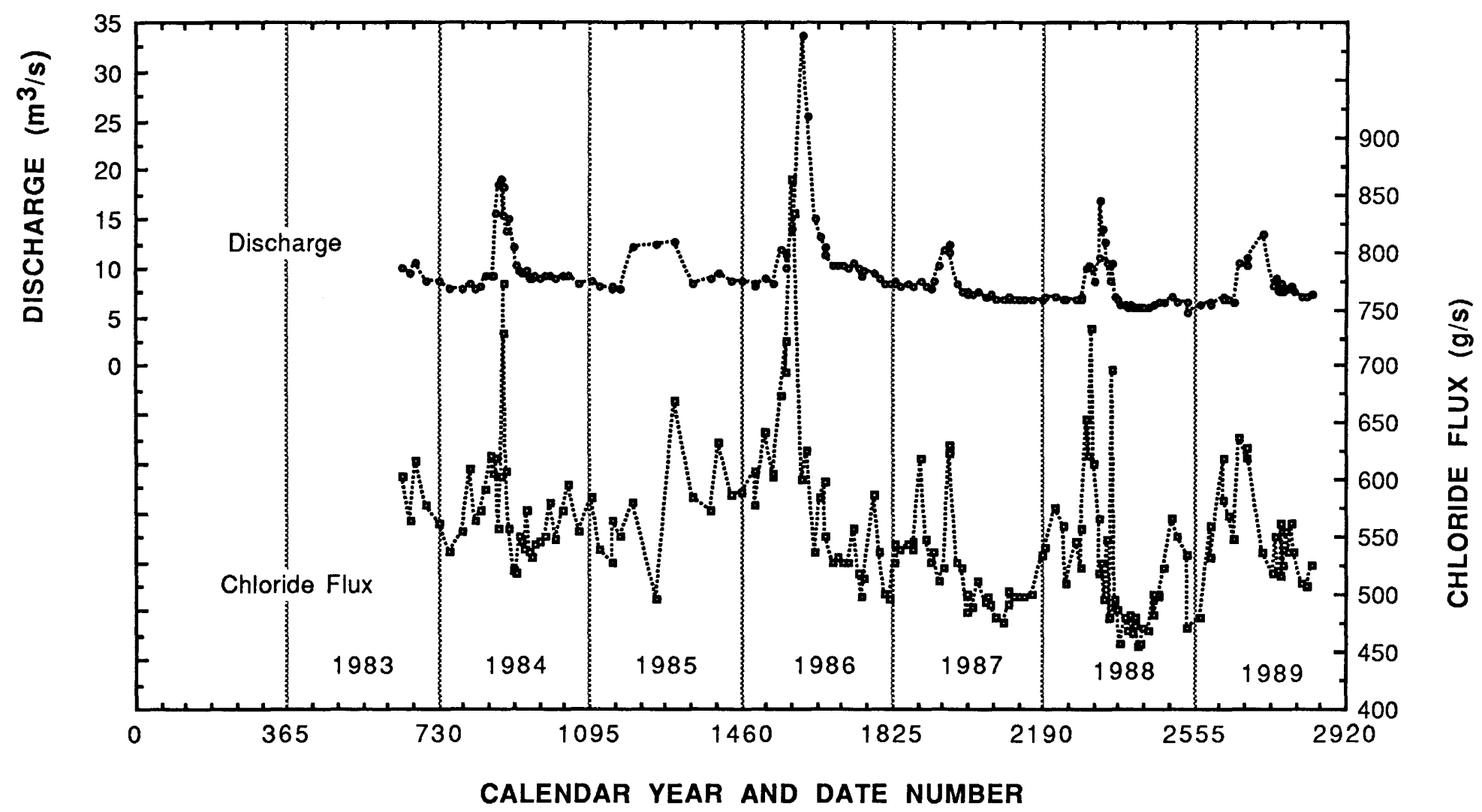

Figure 9. Graphs of the instantaneous discharge in cubic meters per second $\left(\mathrm{m}^{3} / \mathrm{s}\right)$ and the chloride flux in grams per second $(\mathrm{g} / \mathrm{s})$ for the Firehole River. Plotted points are from data given in the appendix. Calendar years are shown. 
Gibbon River

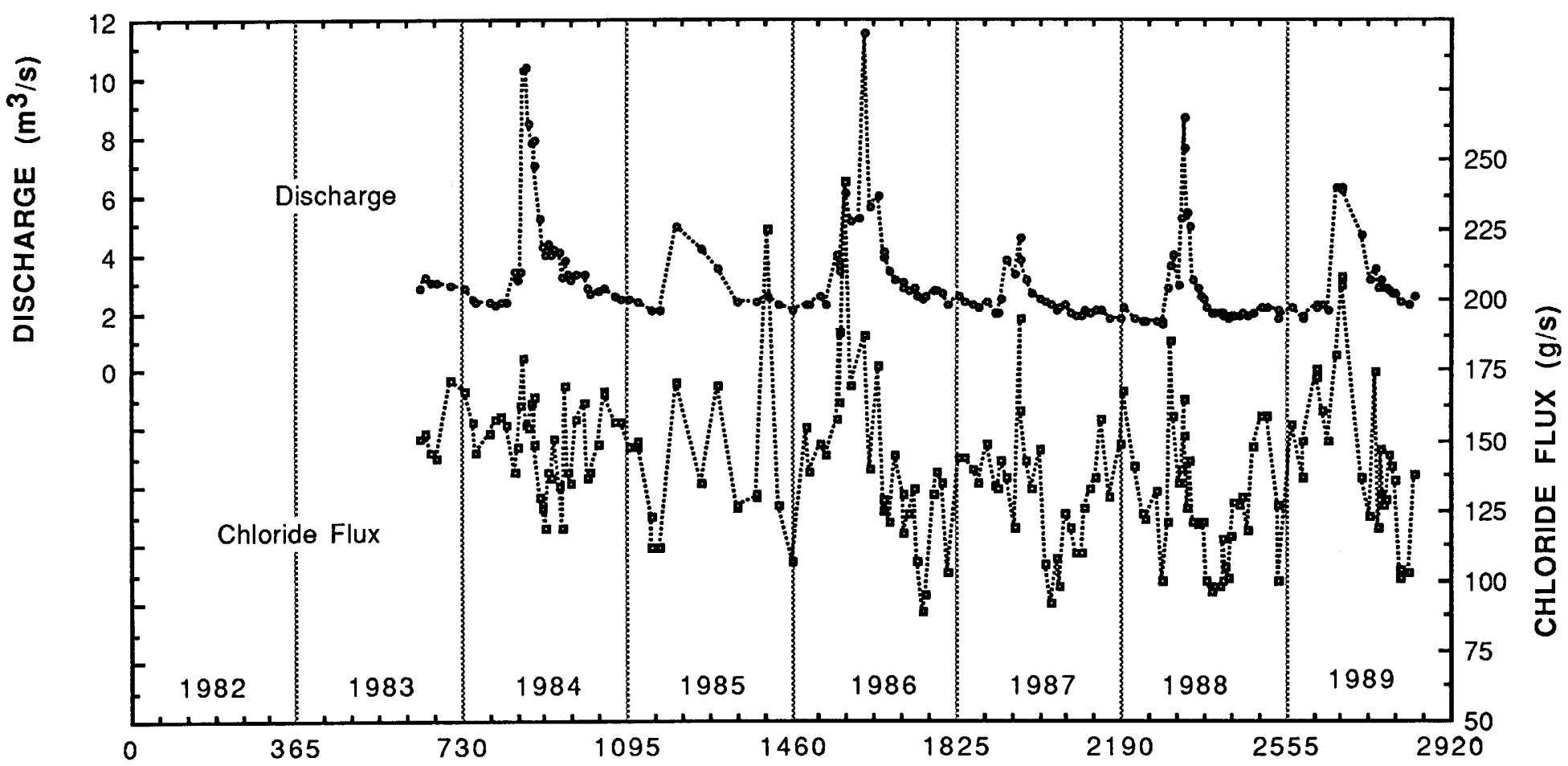

Figure 10. Graphs of the instantaneous discharge in cubic meters per second $\left(\mathrm{m}^{3} / \mathrm{s}\right)$ and the chloride flux in grams per second $(\mathrm{g} / \mathrm{s})$ for the Gibbon River. Plotted points are from data given in the appendix. Calendar years are shown. 


\section{Snake River}

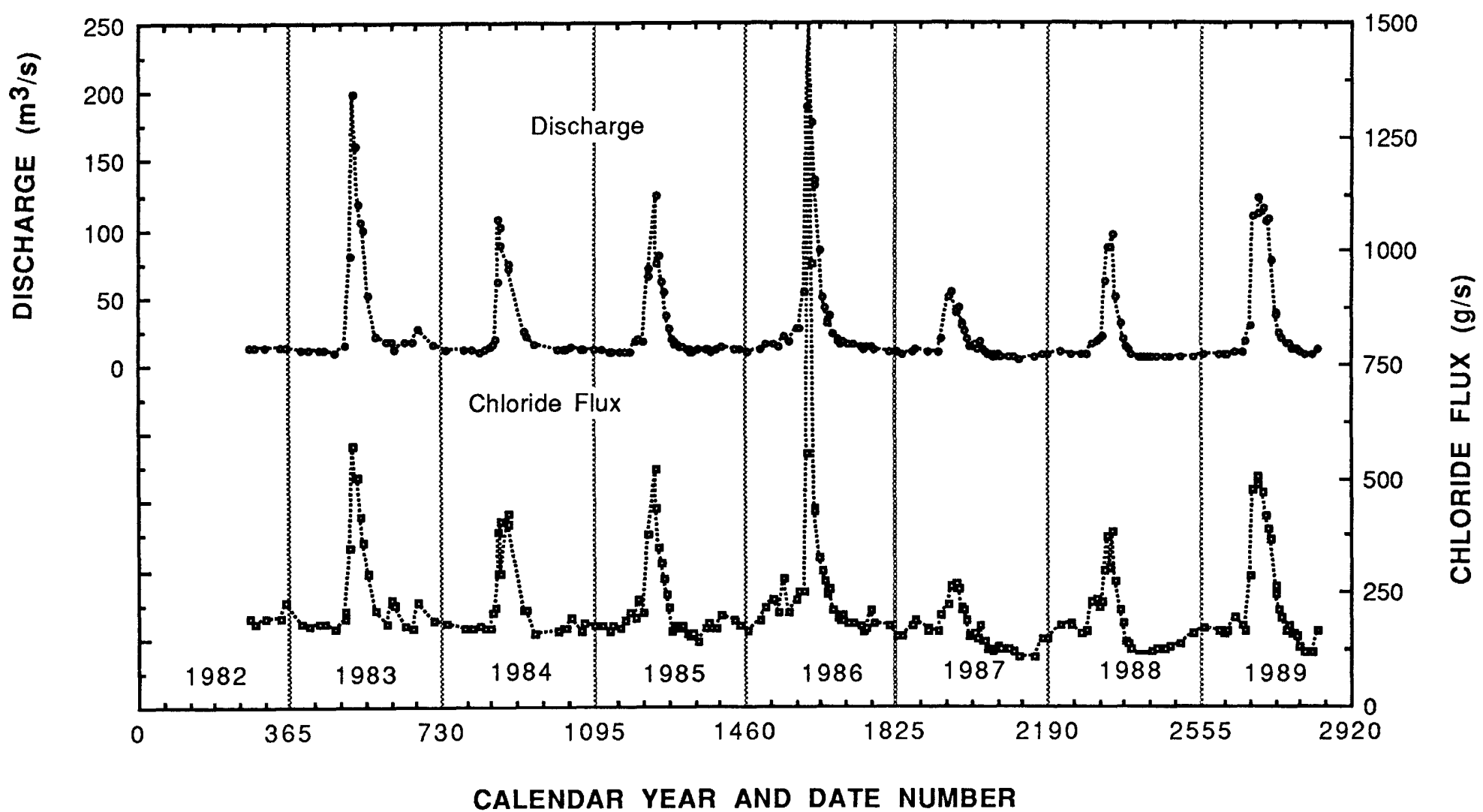

Figure 11. Graphs of the instantaneous discharge in cubic meters per second $\left(\mathrm{m}^{3} / \mathrm{s}\right)$ and the chloride flux in grams per second $(\mathrm{g} / \mathrm{s})$ for the Snake River. Plotted points are from data given in the appendix. Calendar years are shown. 
Yellowstone River

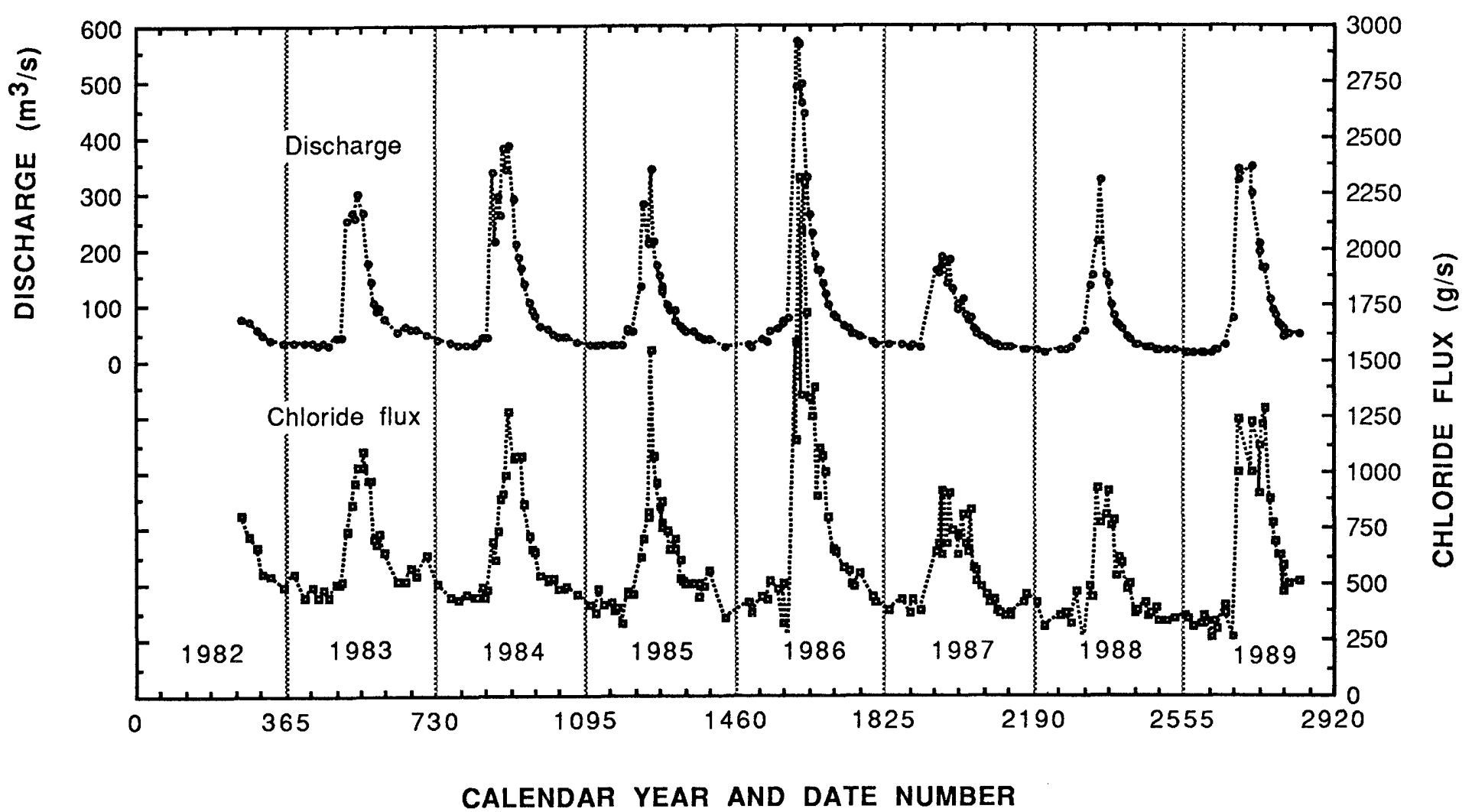

Figure 12. Graphs of the instantaneous discharge in cubic meters per second $\left(\mathrm{m}^{j} / \mathrm{s}\right)$ and the chloride flux in grams per second $(\mathrm{g} / \mathrm{s})$ for the Yellowstone River. Plotted points are from data given in the appendix. Calendar years are shown. 


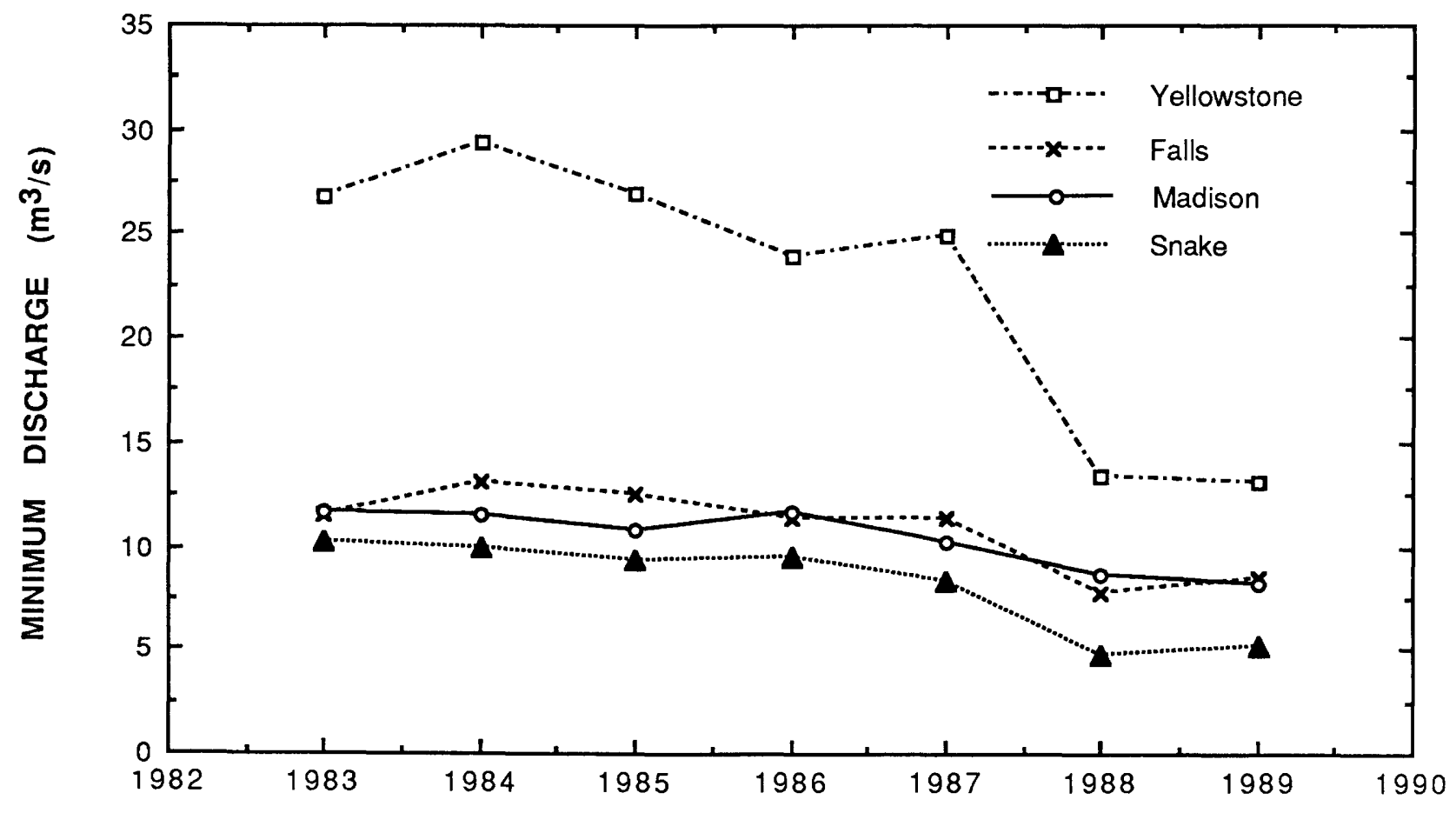

WATER YEAR

Figure 13. Graph of the minimum discharge, in cubic meters per second $\left(\mathrm{m}^{3} / \mathrm{s}\right)$ for the Yellowstone, Falls, Madison, and Snake Rivers for water years 1983 through 1989. Note that the plotted minimum flows are from our data, not from data published by the U.S. Geological Survey in its annual report of river discharge.

chloride concentration in snow to be about $2 \mathrm{ppm}$ for the Snake and Yellowstone Rivers, $7 \mathrm{ppm}$ for the Madison River, and about $1 \mathrm{ppm}$ for the Falls River, to account for the peaks in chloride flux during spring runoff. Calculated chloride concentrations of the annual snowpack from chemical analysis of snow samples collected at Tower station in Yellowstone from 1981-1988 ranges from 0.05 to $0.23 \mathrm{ppm}$ with an average value of $0.15 \mathrm{ppm}$. Discussions of these factors are given in Norton and Friedman (1985) and Friedman and Norton (1990). In our 1985 paper we suggested that the peaks are due primarily to stored chloride, but reconsideration of the data leads us to question this earlier conclusion.

\section{Estimated Chloride Flux in Addition to That From the Four Major Rivers}

In a previous paper (Norton and Friedman, 1985), we identified chloride discharges near the western boundary of the Park into the Island Park Geothermal Area. These discharges are a few kilometers west of the Park boundary and probably originate mainly within the Yellowstone geothermal system. They include Big Springs, Buffalo River, Warm River, Robinson Creek, and inflow to the Henrys Fork between Osborne Bridge and the confluence with Warm River (see fig. 2). From data presented by Whitehead (1978), we estimate that 25 percent of the total chloride flux from the western boundary of the Park drains to the Henrys Fork between Osborne Bridge and the confluence of Henrys Fork with Warm River. The remainder exits via Big Springs, Buffalo River, Robinson Creek, and Warm River.

We determined instantaneous chloride flux values at Big Springs, Buffalo River, Robinson Creek, and Warm River from measurements made at base flow in the fall of 1984, 1985, 1988, and 1989. Based on one instantaneous measurement per site for each year, we calculated the total chloride flux for each year. The results were multiplied by 1.33 to correct for the estimated contribution to the Henrys Fork and have been added to the flux from the four rivers in table 6. This chloride flux constitutes 7-9 percent of the total chloride flux that exits the Park. Our previous estimate of 5 percent (Norton and Friedman, 1985) did not include the additional input to the Henrys Fork just mentioned.

La Duke Hot Springs, $9 \mathrm{~km}$ north of the Park boundary, may also be considered part of the Yellowstone Park Geothermal System. From data presented in Norton and others (1989), we estimate that the annual chloride flux from this system does not exceed 0.03 percent of the total from the Park, and we will not discuss it further in this paper. 


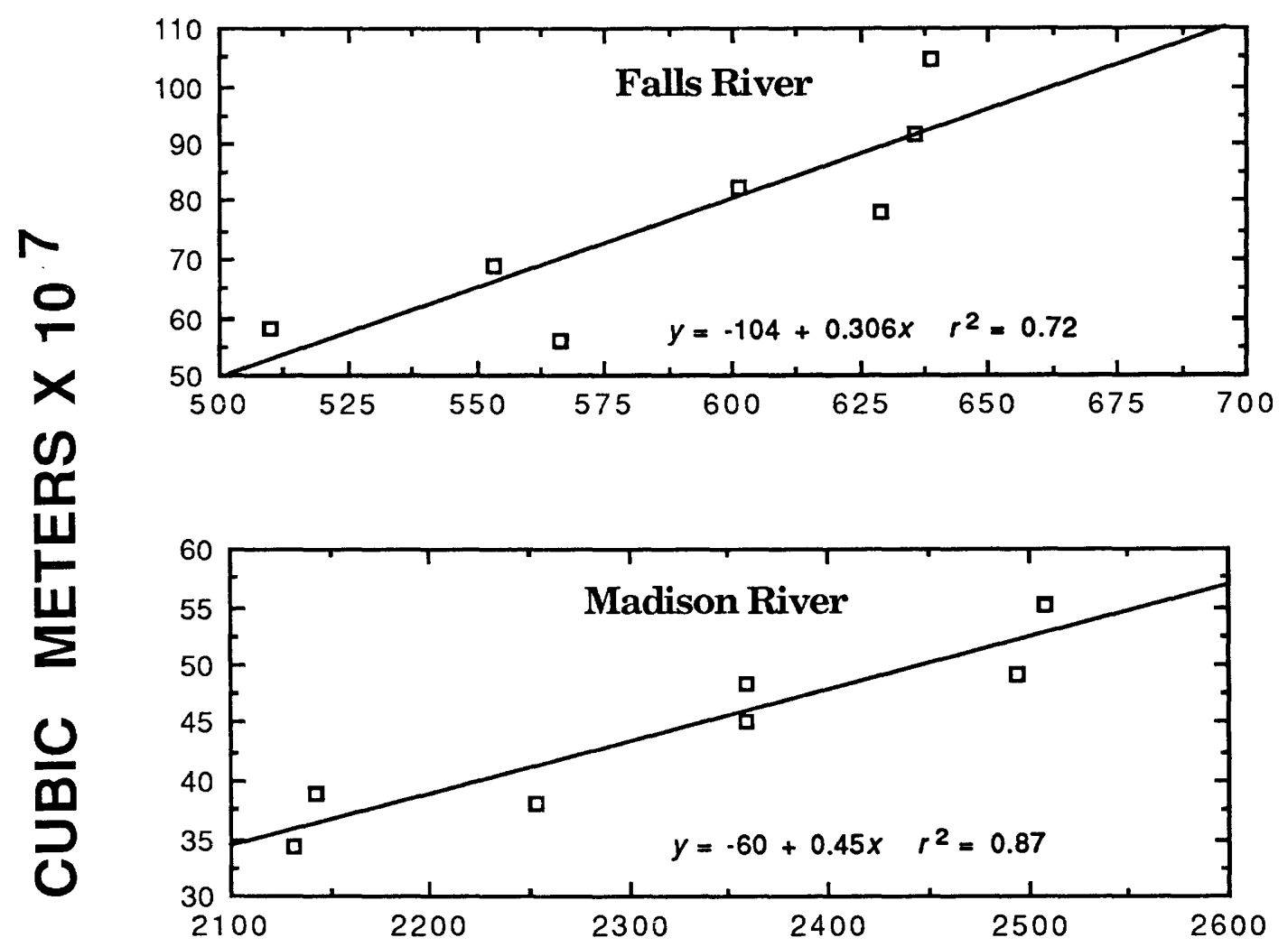

$\underline{z}$

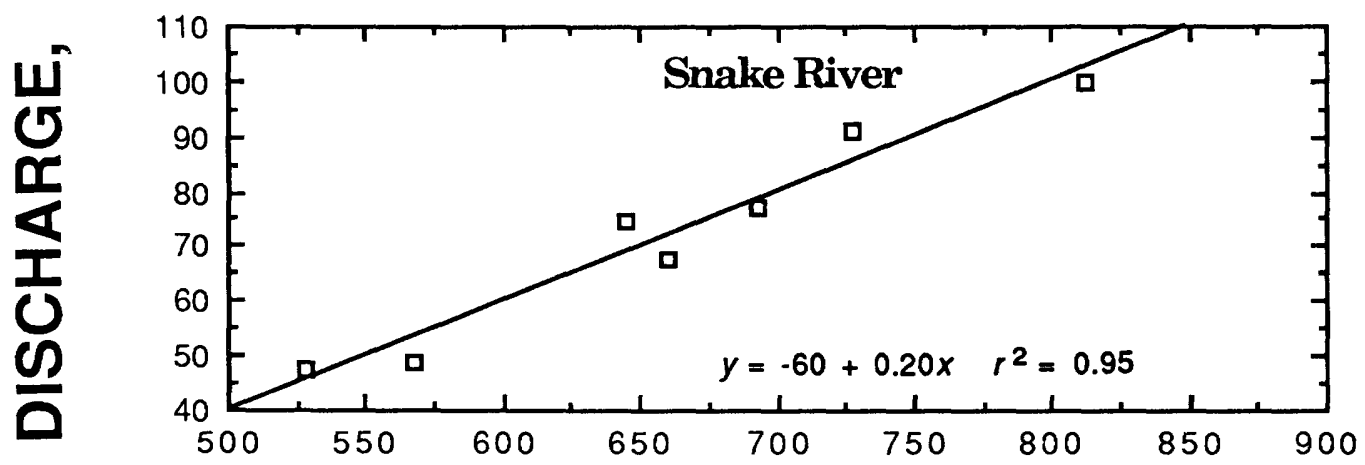

主

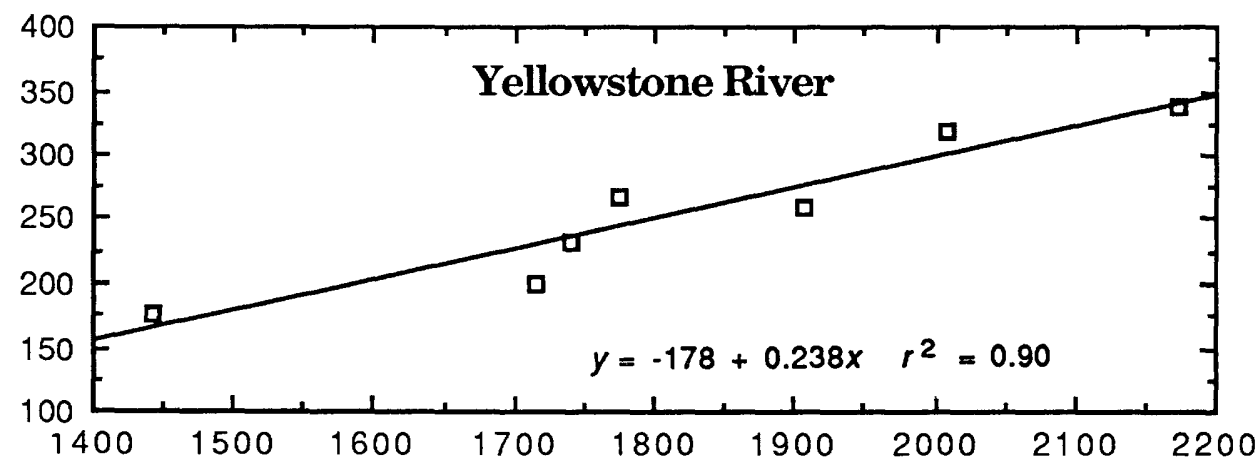

\section{ANNUAL CHLORIDE, IN GRAMS X 107}

Figure 14. Graphs of the annual chloride flux versus discharge for the Falls, Madison, Snake, and Yellowstone Rivers for water years 1983 through 1989. Solid lines are linear least-mean-square solutions to the data. Equations of these lines are also shown. $y$, annual discharge; $x$, annual chloride; $r^{2}$, correlation coefficient squared. 


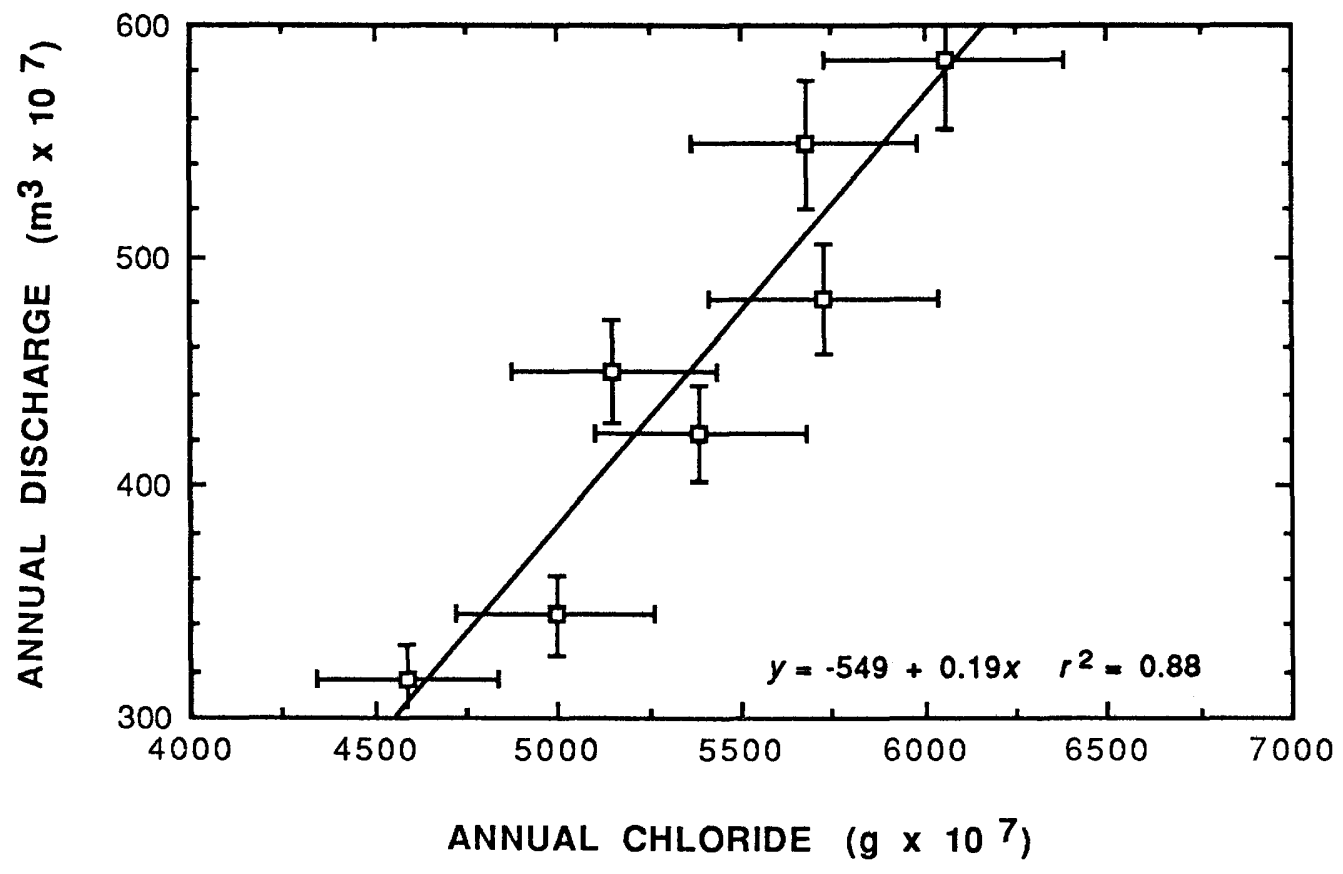

A

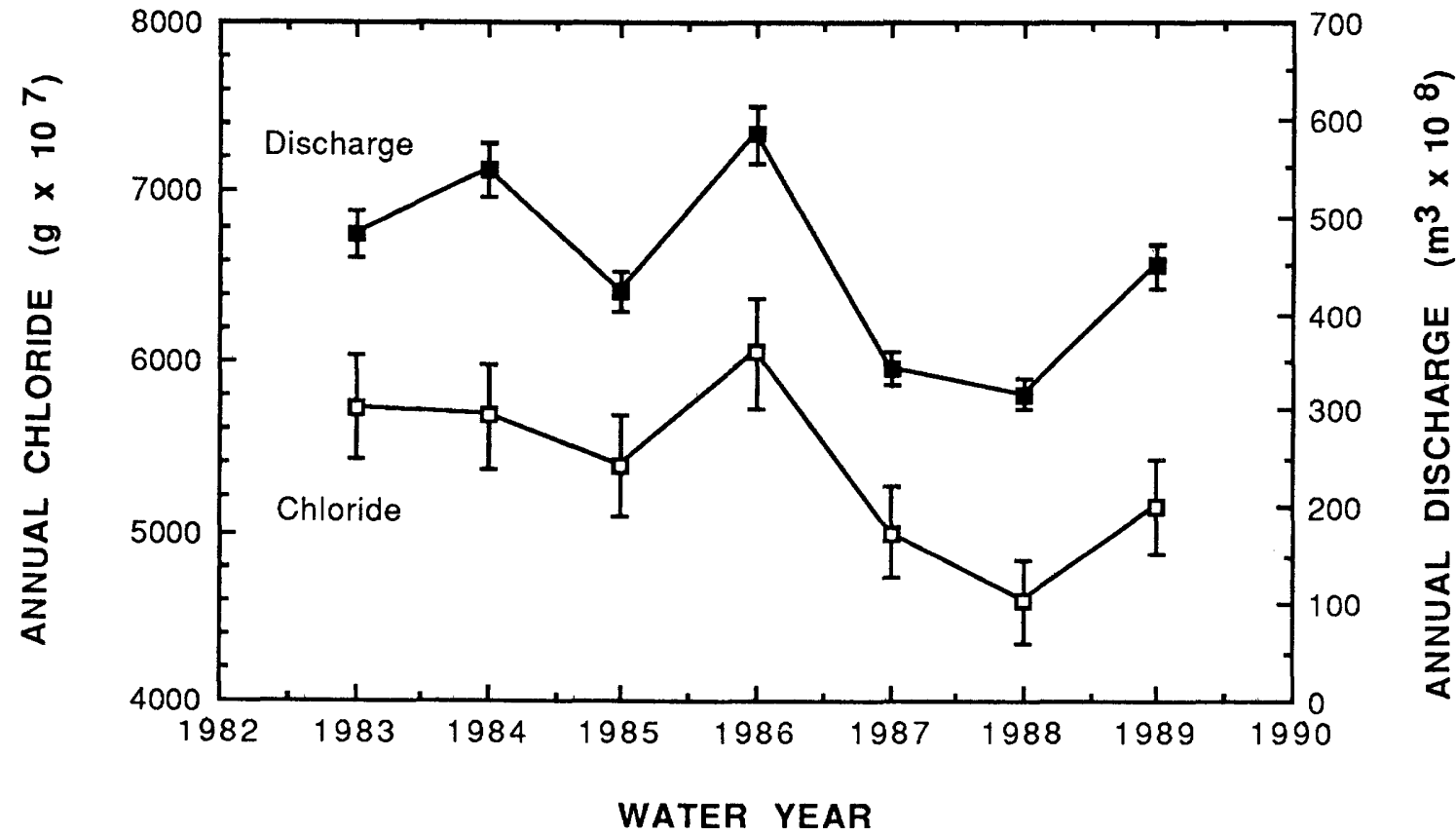

B

Figure 15. Graphs of $(A)$ the total annual chloride flux exiting Yellowstone National Park via the Falls, Madison, Snake, and Yellowstone Rivers versus the total annual discharge of these rivers; and $(B)$ the total annual discharge of the sum of the four rivers and the total annual chloride discharged from the same four rivers. All data for water years 1983 through 1989. 

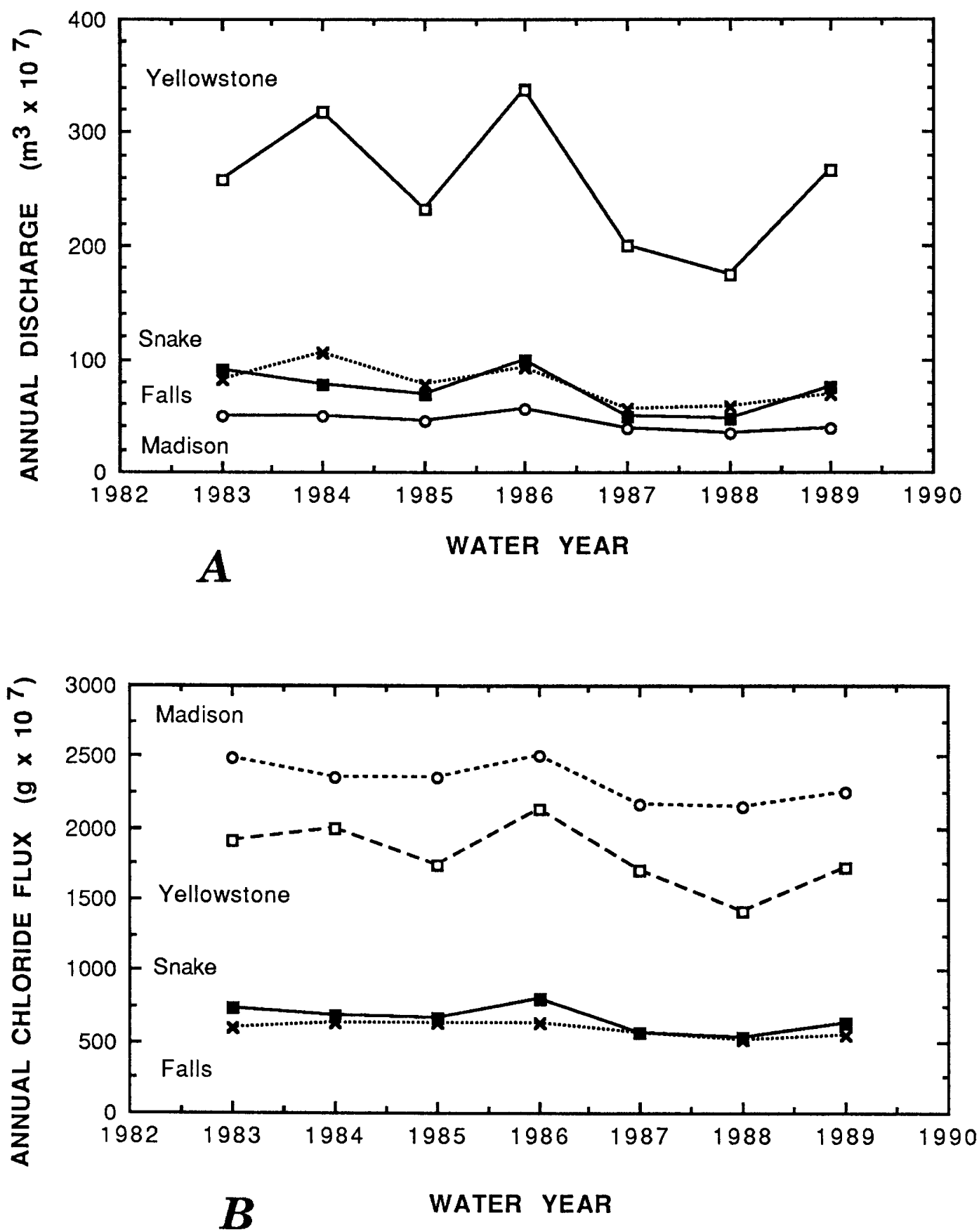

Figure 16. Graphs of $(A)$ the annual discharges versus time of the Falls, Madison, Snake, and Yellowstone Rivers; and $(B)$ the annual chloride fluxes versus time of the four rivers. All data for water years 1983 through 1989.

\section{Geothermal Chloride Flux}

The chloride flux of geothermal origin has been calculated using the method of Norton and Friedman (1985). In this method of calculation the human contribution of chloride is negligible, and all the measured instantaneous chloride concentrations (shown in the appendix) have been reduced by $0.7 \mathrm{ppm}$ to compensate for the chloride added to the rivers by rock weathering $(0.5$ $\mathrm{ppm})$ and by atmospheric precipitation $(0.2 \mathrm{ppm})$. R.O Fournier says (written commun., 1990) that good arguments can be made that the average nonthermal background chloride ranges from 2 to $3 \mathrm{ppm}$, but we disagree with his interpretation. 
We then recalculated both instantaneous and integrated values of flux using the reduced chloride values. The percentage of annual geothermal chloride compared with the total annual chloride exiting the Park for the water years 1983-86 agrees with the value of 94 percent found earlier by Norton and Friedman (1985). The model proposed by Fournier (1990) would result in a lower value for the geothermal contribution (approximately 85-90 percent geothermal). Although the issue of the actual amount of nonhydrothermal chloride contributed by rock weathering remains to be resolved, we believe that the following values will not be greatly affected.

According to our model, the rivers draining the Park contribute varying proportions of geothermal versus total chloride. About 99 percent of the chloride exiting via the Madison River (4 years of data) is of geothermal origin, whereas 90 percent of the chloride exiting via the Yellowstone River (6 years of data) is geothermal. The values for the Falls and Snake Rivers are 91 percent (6 years) and 92 percent (6 years), respectively.

We have calculated the amount of heat flux (in percentage of the total exiting the Park) contributed from the following thermal areas of the Park based upon the fact that geothermal chloride flux is directly related to heat flux: 34 percent from thermal areas in the Firehole River drainage, including the Lone Star, Upper Geyser, Midway Geyser, and Lower Geyser Basins;

30 percent from thermal areas in the Yellowstone River drainage, which include West Thumb Geyser Basin and other thermal areas in and around the shores of Yellowstone Lake, Hot Springs Basin Group, Sulfur Cauldron Hot Springs, Grand Canyon of the Yellowstone Hot Springs, Calcite Springs, and Mammoth Hot Springs;

12 percent from thermal areas in the Snake River drainage basin, including the Shoshone Geyser Basin, Heart Lake Geyser Basin, and the Snake River Hot Springs;

10 percent from thermal areas in the Falls River drainage basin which include Boundary Creek, Bechler River, Mountain Ash Creek, and Upper Falls River;

8 percent from thermal areas in the Gibbon River Drainage Basin including the Norris Geyser Basin; and

6 percent from drainage areas out of the west boundary of the Park into the Island Park Geothermal Area, which include thermal springs of Robinson Creek, Warm River, Buffalo River, Big Springs, and other thermal discharges into the Henrys Fork.

\section{Previous Investigations}

Fournier (1989) discussed the chloride flux discharging from rivers draining the Park using data from Fournier and others (1976) as corrected utilizing the results of Norton and Friedman (1985). He stated that his value of thermal chloride flux from Yellowstone for 1983 was 17 percent less than that found by Norton and Friedman (1985). $\mathrm{He}$ also stated that "the chloride flux measured in 1983 appears to be exceptionally high compared not only with the 1966-67 measurements, but also with measurements made in subsequent years," and he quoted "USGS unpublished data." The only published data for chloride flux out of the Park for years previous to 1983 was based on intermittent values (Fournier and others 1976). They reported only six instantaneous values for Madison River, four for the Yellowstone River, and no data for the Falls and Snake Rivers for 1966-1967. Our work is based on 37 values per year for each of the four rivers, and these values were integrated to yield annual fluxes.

Fournier's (1989) conclusion that the chloride flux in 1983 was relatively high compared with other years was based on instantaneous flux measurements at low stages of flow, and he used our old (1985) values for stream flow for the Madison River, which gave flux values about 17 percent higher than our revised values presented here (see fig. 1). Using these revised discharge values, Fournier (written commun., 1990) now agrees that the flux of hydrothermal chloride was not exceptionally high in 1983.

\section{Borah Peak Earthquake of October 28, 1983}

As stated in Norton and Friedman (1985), all four rivers draining the park showed a distinct increase in chloride flux beginning in early October 1983 and culminating shortly after the Borah Peak earthquake. The magnitude and duration of these increases was insufficient to appear as a significant increase in the annual fluxes for these rivers, in contrast to the statement of Fournier (1989).

\section{Yellowstone Fires of 1988}

The impact of the extensive fires during the summer of 1988 does not appear to have significantly affected the amount of chloride flux for the following water year. Although the chloride flux did increase in 1989, this increase can be attributed to the increase in discharge observed for that year. 
Table 6. Calculated precipitation in selected river basins of Yellowstone National Park

$\left[\mathrm{km}^{2}\right.$, square kilometer]

\begin{tabular}{|c|c|c|c|c|c|c|c|c|c|}
\hline \multirow[t]{2}{*}{ River basin } & \multirow{2}{*}{$\begin{array}{c}\text { Area } \\
\left(\mathrm{km}^{2}\right)\end{array}$} & \multicolumn{8}{|c|}{ Calculated precipitation (in centimeters) } \\
\hline & & 1983 & 1984 & 1985 & 1986 & 1987 & 1988 & 1989 & $\begin{array}{c}7 \text {-year } \\
\text { average }\end{array}$ \\
\hline Falls & 909 & 91 & 115 & 67 & 101 & 62 & 64 & 76 & 82 \\
\hline Madison & 1088 & 45 & 45 & 42 & 51 & 36 & 32 & 35 & 41 \\
\hline Snake & 405 & 225 & 190 & 168 & 247 & 121 & 118 & 185 & 179 \\
\hline Yellowstone & 6793 & 38 & 47 & 34 & 50 & 30 & 26 & 39 & 38 \\
\hline \multicolumn{3}{|c|}{ Precipitation at Tower Station ${ }^{1} 32$} & 41 & 34 & 41 & $(2)$ & 27 & $(2)$ & \\
\hline
\end{tabular}

1 Data from National Atmospheric Deposition Program (1989), measured values.

2 Data incomplete for this year.

\section{Use of Discharge Data to Calculate Precipitation}

Precipitation is known to vary greatly from area to area within the Park. The discharge data from the rivers draining the Park can be used to reconstruct precipitation within the drainage areas of these rivers. The annual discharge of each river divided by the area of the drainage basin yields a calculated precipitation value for that basin for the year. This approximation procedure assumes a steady-state condition wherein all precipitation during the year leaves as runoff and ignores the variations in both annual water storage and losses by evapo-transpiration (the loss due to evapo-transpiration is thought to be small and most of this water probably returns to the system via thunderstorms (see Friedman, 1977)). Because these variables tend to be similar from one year to the next, the precipitation calculated by this method can be used to compare the precipitation between drainage basins for a particular year, as well as from year to year. The calculated precipitation data for the four major river basins are given in table 6 and show that the precipitation increased during 1986 compared with the previous 3 years, decreased to about one-half the 1986 values for 1987 and 1988, and increased somewhat in 1989.

Long-term climatic records in the Park are recorded in the National Oceanic and Atmospheric Administration (NOAA) Report titled "Climatological Data Annual Summary, Wyoming." These summaries list stations at Yellowstone Park (Mammoth), Tower Falls, Lake Yellowstone, Old Faithful, and Snake River. The record for these stations are incomplete and cannot be used for climatic studies. In addition to these NOAA stations, another source of precipitation data is available. An automated station at Tower Falls in the Yellowstone River drainage basin has been operated under the National Atmospheric Deposition Program (1989). The data from this station is presented in table 6 and shows a good correlation with our calculated precipitation in the Yellowstone drainage basin, also listed in table 6.

\section{CONCLUSIONS}

Based on long-term records of discharge of the Falls, Madison, and Yellowstone rivers, we conclude that data from the 7 years of our study are within the norm for the long-term record.

For the purpose of integrating discharge and chloride flux over long periods of time, we demonstrated that our sampling program, which is based upon an increased sampling rate during periods of high discharge, is necessary to provide the required accuracy for a meaningful monitoring program. In addition, the accuracy of the routine chloride determinations had to be increased by normalizing the raw data against frequently inserted gravimetric standard chloride solutions.

Our data show a high correlation between river discharge and chloride flux. We attribute this to changes in heights of the water tables, which in turn affect the discharge rates of thermal springs. Because most thermal springs have constant chloride concentration, river discharge and chloride flux can be correlated directly.

There are large variations on various time scales in both integrated chloride flux and discharge as measured by monitoring the four major rivers exiting the Park. All the 
rivers show seasonal variations related to snowmelt in the spring. The rivers that drain major thermal areas also show short-time variations unrelated to these seasonal effects. We attribute these short-time variations to changes in thermal activity in the related geyser basins. This change in thermal activity may be caused by tectonic changes triggered by earthquakes, or by other changes in the magma system that affect the rate at which chloride reaches the surface. The Borah Peak earthquake of October 28, 1983, $240 \mathrm{~km}$ west of Old Faithful, appeared to have increased the discharge and chloride flux of the Falls, Madison, and Snake rivers for a short time beginning a few weeks before the earthquake and ending after the earthquake. The Yellowstone River also shows a small increase in chloride flux during this same period, but without a noticeable increase in discharge. This effect might be due to the much greater discharge of the Yellowstone relative to the other rivers, which would mask the effect of a small increase in the input of thermal water.

We did not observe any measurable effect of the great Yellowstone fires of 1988 upon our chloride flux measurements.

During the period of this study, we observed a decline in the minimum discharge or base flow of all of the rivers, which may reflect long-term reduced precipitation.

The use of discharge records for the major rivers draining the Park permits a calculation of the annual precipitation on each of the associated drainage basins. This calculation shows that the average precipitation, neglecting small losses by evapo-transpiration, during these 7 years was $82 \mathrm{~cm}$ for the Falls drainage, $41 \mathrm{~cm}$ for the Madison, $179 \mathrm{~cm}$ for the Snake, and $38 \mathrm{~cm}$ for the Yellowstone.

Using calculated values of geothermal chloride for the different drainage basins of the Park, we conclude that 34 percent of the total heat flux from Yellowstone Park is derived from the Firehole River drainage basin. Similar calculations show 30 percent from the Yellowstone River drainage basin, 12 percent from the Snake, 10 percent from the Falls, 8 percent from the Gibbon, and 6 percent from drainages adjacent to the west boundary of the Park.

Inasmuch as about 43 percent of the chloride flux exiting the Park is derived from the Madison River, we recommend that the gauging station on the Madison River, where the river exits the Park, be reactivated and continually monitored, avoiding the uncertainty associated with the use of the stations on the Firehole and Gibbon Rivers to reconstruct the chloride flux exiting the Park via the Madison River.
Investigation of the chloride flux exiting near the west boundary of the Park shows that this flux represents a significant part of the chloride exiting the park. Therefore, we propose that sites in this area be monitored on a regular basis as part of a continuing study.

The data generated during the 7 years of our study showed large annual changes in the chloride flux exiting the Park. Most of these changes are attributed to changes in the height of the water table, which in turn was caused by changes in annual precipitation, and, therefore, long-term records of chloride flux are required to separate changes attributable to climate from those caused by geological events or by the influence of human activity.

\section{REFERENCES CITED}

Fournier, F.O., 1989, Geochemistry and dynamics of the Yellowstone Park hydrothermal system: Annual Review of Earth and Planetary Science, v. 17, p. 13-53.

Fournier, F.O., White, D.E., and Truesdell, A.H., 1976, Convective heat flow in Yellowstone National Park, in Proceedings of the $2 \mathrm{~d}$ United Nations symposium on the development and use of geothermal resources, San Francisco, 1975, v. 1: Washington, D.C., U.S. Government Printing Office, p. 731-739.

Friedman, I., 1977, The Amazon Basin; another Sahel?: Science, v. 197, p. 7.

Friedman, I., and Norton, D.R., 1990, Anomalous chloride flux discharges from Yellowstone National Park: Journal of Volcanology and Geothermal Research, v. 42, p. 225-234..

National Atmospheric Deposition Program, 1989, Data report; Precipitation chemistry: Fort Collins, Colo., Colorado State University, Natural Resource Ecology Laboratory.

Norton, D.R., and Friedman, I., 1985, Chloride flux out of Yellowstone National Park: Journal of Volcanology and Geothermal Research, v. 26, p. 231-250.

Norton, D.R., Friedman, I., Mohrman, J., and Hutchinson, R.A., 1989, Monitoring of thermal activity in the northern part of Yellowstone National Park and vicinity; Part 1-February 1985-June 1988: U.S. Geological Survey Open-File Report 89-211, 35 p.

Skougstad, M.W., Fishman, M.J., Friedman, L.C., Erdmann, D.E., and Duncan, S.S., editors, 1979, Methods for determination of inorganic substances in water and fluvial sediments: U.S. Geological Survey Techniques of Water-Resources Investigations, book 5, chap. A1, $626 \mathrm{p}$.

Whitehead, R.L., 1978, Water resources of the upper Henrys Fork basin in eastern Idaho: U.S. Geological Survey and Idaho Department of Water Resources Information Bulletin, v. 46, 81 p. 


\section{APPENDIX}

Sample-data record showing date and time of collection, chloride concentration of sample, river discharge, and chloride flux for individual collections and for interpolated end-of-month values; all for the Falls, Firehole, Gibbon, Madison, Snake, and Yellowstone Rivers for the water years 1983 through 1989.

[ppm, parts per million; $\mathrm{m}^{3} / \mathrm{s}$, cubic meters per second; $\mathrm{g} / \mathrm{s}$, grams per second; water year is 12 months beginning October 1 ]

${ }^{1}$ Date number 1 is January $1,1980$.

${ }^{2}$ Where no time is reported, the chloride concentration and all other data shown are interpolated values. 


\begin{tabular}{lcccc}
\hline $\begin{array}{l}\text { Day- } \\
\text { month- }\end{array}$ & $\begin{array}{c}\text { Date } 1 \\
\text { year }\end{array}$ & No. & Time 2 & \multicolumn{3}{c}{ Instantaneous values } \\
\cline { 2 - 5 } & & $\begin{array}{c}\text { Chloride } \\
\mathrm{mg} / \mathrm{L}\end{array}$ & $\begin{array}{c}\text { Discharge } \\
\text { y/s }\end{array}$ & $\begin{array}{c}\mathrm{Cl} \text { flux } \\
\mathrm{g} / \mathrm{s}\end{array}$ \\
\hline \multicolumn{4}{c}{ Falls River }
\end{tabular}

Water year 1983:

$\begin{array}{lllrll}\text { 30-Sep-82 } & 273 & & 9.7 & 20.3 & 197 \\ \text { 21-Oct-82 } & 294 & 1630 & 9.9 & 18.7 & 186 \\ \text { 31-Oct-82 } & 304 & & 9.8 & 18.9 & 184 \\ \text { 10-Nov-82 } & 314 & 1025 & 9.6 & 19.0 & 182 \\ \text { 30-Nov-82 } & 334 & 1030 & 11.0 & 18.7 & 206 \\ \text { 19-Dec-82 } & 353 & 1235 & 12.5 & 16.1 & 201 \\ \text { 31-Dec-82 } & 365 & & 12.4 & 15.3 & 190 \\ \text { 26-Jan-83 } & 391 & 1020 & 12.1 & 13.7 & 166 \\ \text { 31-Jan-83 } & 396 & & 12.3 & 13.5 & 166 \\ \text { 23-Feb-83 } & 419 & 1010 & 13.0 & 12.6 & 164 \\ & & & & & \\ \text { 28-Feb-83 } & 424 & & 13.1 & 12.7 & 166 \\ \text { 8-Mar-83 } & 432 & 1010 & 13.2 & 12.8 & 169 \\ \text { 21-Mar-83 } & 445 & 1730 & 13.8 & 12.8 & 176 \\ \text { 31-Mar-83 } & 455 & & 13.5 & 12.0 & 162 \\ \text { 5-Apr-83 } & 460 & 1535 & 13.4 & 11.6 & 155 \\ \text { 19-Apr-83 } & 474 & 1430 & 11.4 & 16.1 & \\ \text { 30-Apr-83 } & 485 & & 9.0 & 27.4 & 247 \\ \text { 2-May-83 } & 487 & 1350 & 8.6 & 29.4 & 253 \\ \text { 9-May-83 } & 494 & 1745 & 7.2 & 38.5 & 277 \\ \text { 17-May-83 } & 502 & 1000 & 8.8 & 26.4 & 232 \\ & & & & & \\ \text { 23-May-83 } & 508 & 0950 & 4.1 & 67.7 & 277 \\ \text { 31-May-83 } & 516 & 1035 & 2.7 & 99.4 & 268 \\ \text { 7-Jun-83 } & 523 & 0925 & 3.0 & 83.8 & 251 \\ \text { 14-Jun-83 } & 530 & 0955 & 3.3 & 73.3 & 242 \\ \text { 22-Jun-83 } & 538 & 1300 & 3.6 & 60.3 & 217 \\ \text { 27-Jun-83 } & 543 & 0910 & 3.5 & 65.8 & 230 \\ \text { 30-Jun-83 } & 546 & & 3.5 & 58.7 & 206 \\ \text { 6-Jul-83 } & 552 & 0830 & 3.5 & 44.6 & 156 \\ \text { 11-Jul-83 } & 557 & 0840 & 4.2 & 55.2 & 232 \\ \text { 18-Jul-83 } & 564 & 0910 & 5.3 & 31.4 & 167 \\ & & & & & \\ \text { 26-Jul-83 } & 572 & 1000 & 6.7 & 24.5 & 164 \\ \text { 31-Jul-83 } & 577 & & 7.2 & 21.9 & 158 \\ \text { 1-Aug-83 } & 578 & 1030 & 7.3 & 21.4 & 156 \\ \text { 9-Aug-83 } & 586 & 0915 & 7.7 & 18.3 & 141 \\ \text { 16-Aug-83 } & 593 & 0905 & 7.7 & 20.1 & 155 \\ \text { 29-Aug-83 } & 606 & 0900 & 8.2 & 22.7 & 186 \\ \text { 31-Aug-83 } & 608 & & 8.3 & 22.4 & 185 \\ \text { 13-Sep-83 } & 621 & 0945 & 8.6 & 20.3 & 175 \\ \text { 26-Sep-83 } & 634 & 1230 & 9.6 & 16.3 & 156 \\ \text { 30-Sep-83 } & 638 & & 9.4 & 18.5 & 173 \\ & & & & & \end{array}$

Water Year 1984:

$\begin{array}{llllll}\text { 12-Oct-83 } & 650 & 0920 & 8.7 & 25.0 & 218 \\ \text { 25-Oct-83 } & 663 & 1100 & 9.7 & 26.2 & 254 \\ \text { 31-Oct-83 } & 669 & & 8.6 & 28.9 & 249 \\ \text { 8-Nov-83 } & 677 & 1335 & 7.2 & 32.5 & 234 \\ \text { 30-Nov-83 } & 699 & & 9.6 & 24.2 & 231 \\ & & & & & \\ \text { 15-Dec-83 } & 714 & 1530 & 11.2 & 18.5 & 207 \\ \text { 31-Dec-83 } & 730 & & 10.6 & 17.5 & 186 \\ \text { 8-Jan-84 } & 738 & 1056 & 10.3 & 17.0 & 176 \\ \text { 30-Jan-84 } & 760 & 1435 & 11.8 & 15.7 & 185 \\ \text { 31-Jan-84 } & 761 & & 11.8 & 15.6 & 184 \\ & & & & & \\ \text { 29-Feb-84 } & 790 & 1440 & 11.6 & 13.5 & 157 \\ \text { 3-Mar-84 } & 803 & 1345 & 11.9 & 13.3 & 158 \\ \text { 26-Mar-84 } & 816 & 1520 & 11.6 & 13.7 & 159\end{array}$

\begin{tabular}{lccccc}
\hline Day & Date 1 & Time 2 & \multicolumn{3}{c}{ Instantaneous values } \\
\cline { 3 - 6 } month- & No. & \multicolumn{2}{c}{ Chloride } & Discharge & $\mathrm{Cl} \mathrm{flux}$ \\
year & & $\mathrm{mg} / \mathrm{L}$ & $\mathrm{m}^{3} / \mathrm{s}$ & $\mathrm{g} / \mathrm{s}$
\end{tabular}

Falls River

$\begin{array}{llllll}\text { 31-Mar-84 } & 821 & & 11.7 & 13.4 & 156 \\ \text { 4-Apr-84 } & 825 & 1400 & 11.7 & 13.1 & 153 \\ \text { 22-Apr-84 } & 843 & 1930 & 7.0 & 24.7 & 173 \\ \text { 30-Apr-84 } & 851 & 1035 & 7.7 & 21.9 & 162 \\ \text { 8-May-84 } & 859 & 0950 & 6.7 & 21.9 & 141 \\ \text { 15-May-84 } & 866 & 1004 & 3.0 & 106 & 319 \\ & & & & & \\ \text { 21-May-84 } & 872 & 1025 & 3.1 & 111 & 345 \\ \text { 29-May-84 } & 880 & 1740 & 3.1 & 77.3 & 327 \\ \text { 31-May-84 } & 882 & & 3.1 & 103 & 315 \\ \text { 8-Jun-84 } & 890 & 0645 & 2.9 & 93.7 & 269 \\ \text { 13-Jun-84 } & 895 & 1955 & 4.0 & 65.7 & 263 \\ & & & & & \\ \text { 19-Jun-84 } & 901 & 1915 & 3.1 & 88.3 & 274 \\ \text { 25-Jun-84 } & 907 & 2030 & 2.7 & 102 & 278 \\ \text { 30-Jun-84 } & 912 & 1030 & 2.3 & 106 & 244 \\ \text { 9-Jul-84 } & 921 & 1100 & 3.7 & 51.5 & 191 \\ \text { 17-Jul-84 } & 929 & 1005 & 5.2 & 32.6 & 169 \\ & & & & & \\ \text { 24-Jul-84 } & 936 & 0908 & 5.8 & 31.4 & 182 \\ \text { 30-Jul-84 } & 942 & 2050 & 6.4 & 28.6 & 183 \\ \text { 31-Jul-84 } & 943 & & 6.4 & 28.1 & 180 \\ \text { 9-Aug-84 } & 952 & 0757 & 6.3 & 23.5 & 148 \\ \text { 15-Aug-84 } & 958 & 0710 & 7.9 & 22.4 & 177 \\ & & & & & \\ \text { 23-Aug-84 } & 966 & 1030 & 7.2 & 23.5 & 169 \\ \text { 29-Aug-84 } & 972 & 1005 & 7.5 & 24.7 & 185 \\ \text { 31-Aug-84 } & 974 & & 7.7 & 24.0 & 186 \\ \text { 9-Sep-84 } & 983 & 1855 & 8.8 & 20.8 & 183 \\ \text { 23-Sep-84 } & 997 & 1855 & 9.0 & 21.9 & 197 \\ & & & & & \\ \text { 30-Sep-84 } & 1004 & & 9.1 & 19.3 & 176 \\ & & & & & \end{array}$

Water year 1985:

$\begin{array}{lllrll}\text { 9-Oct-84 } & 1013 & 1543 & 9.3 & 16.1 & 150 \\ \text { 22-Oct-84 } & 1026 & 1619 & 10.4 & 15.9 & 165 \\ \text { 31-Oct-84 } & 1035 & & 10.7 & 16.0 & 172 \\ \text { 7-Nov-84 } & 1042 & 0924 & 11.0 & 16.1 & 178 \\ \text { 30-Nov-84 } & 1065 & & 11.6 & 14.8 & 172 \\ & & & & & \\ \text { 4-Dec-84 } & 1069 & 1410 & 11.7 & 14.6 & 171 \\ \text { 31-Dec-84 } & 1096 & & 11.6 & 14.2 & 166 \\ \text { 7-Jan-85 } & 1103 & 0930 & 11.6 & 14.2 & 164 \\ \text { 22-Jan-85 } & 1118 & 1342 & 11.6 & 12.5 & 145 \\ \text { 31-Jan-85 } & 1127 & & 11.7 & 13.5 & 158 \\ & & & & & \\ \text { 12-Feb-85 } & 1139 & 1645 & 11.9 & 14.7 & 175 \\ \text { 19-Feb-85 } & 1146 & 0650 & 14.1 & 16.3 & 230 \\ \text { 28-Feb-85 } & 1155 & & 13.1 & 16.7 & 218 \\ \text { 5-Mar-85 } & 1160 & 1545 & 12.5 & 12.5 & 156 \\ \text { 25-Mar-85 } & 1180 & 0755 & 12.9 & 13.5 & 175 \\ & & & & & \\ \text { 31-Mar-85 } & 1186 & & 13.6 & 14.0 & 189 \\ \text { 3-Apr-85 } & 1189 & 0955 & 13.9 & 14.2 & 197 \\ \text { 15-Apr-85 } & 1201 & 1445 & 9.8 & 27.7 & 271 \\ \text { 29-Apr-85 } & 1215 & 1844 & 8.4 & 33.7 & 283 \\ \text { 30-Apr-85 } & 1216 & & 8.2 & 35.3 & 288 \\ & & & & & \\ \text { 13-May-85 } & 1229 & 1230 & 4.9 & 56.0 & 274 \\ \text { 28-May-85 } & 1244 & 1940 & 3.3 & 91.5 & 302 \\ \text { 31-May-85 } & 1247 & & 3.6 & 75.9 & 270 \\ \text { 4-Jun-85 } & 1251 & 1005 & 3.9 & 55.2 & 215 \\ \text { 9-Jun-85 } & 1256 & 1930 & 3.3 & 82.8 & 273 \\ & & & & & \\ \text { 18-Jun-85 } & 1265 & 0922 & 4.0 & 58.5 & 234 \\ \text { 23-Jun-85 } & 1270 & 2035 & 5.5 & 39.8 & 219 \\ \text { 25-Jun-85 } & 1272 & 0930 & 5.6 & 38.5 & 216 \\ \text { 30-Jun-85 } & 1277 & & 7.3 & 31.0 & 225 \\ & & & & & \end{array}$




\begin{tabular}{lcccc}
\hline Day- & Date 1 & Time 2 & \multicolumn{3}{c}{ Instantaneous values } \\
\cline { 2 - 4 } $\begin{array}{l}\text { month- } \\
\text { year }\end{array}$ & No. & Chloride & Discharge & $\mathrm{Cl} \mathrm{flux}$ \\
$\mathrm{mg} / \mathrm{L}$ & $\mathrm{m} 3 / \mathrm{s}$ & $\mathrm{g} / \mathrm{s}$ \\
\hline \multicolumn{4}{c}{ Falls River }
\end{tabular}

\section{Falls River}

$\begin{array}{llllll}\text { 1-Jul-85 } & 1278 & 0750 & 7.6 & 29.5 & 224 \\ \text { 9-Jul-85 } & 1286 & 0800 & 8.0 & 25.6 & 205 \\ \text { 17-Jul-85 } & 1294 & 0955 & 8.4 & 25.8 & 217 \\ \text { 23-Jul-85 } & 1300 & 0945 & 9.1 & 26.6 & 242 \\ \text { 29-Jul-85 } & 1306 & 0939 & 9.1 & 21.0 & 191 \\ \text { 31-Jul-85 } & 1308 & & 9.2 & 20.8 & 192 \\ & & & & & \\ \text { 6-Aug-85 } & 1314 & 0849 & 9.6 & 20.3 & 195 \\ \text { 13-Aug-85 } & 1321 & 1002 & 9.8 & 18.7 & 183 \\ \text { 20-Aug-85 } & 1328 & 1902 & 10.2 & 16.6 & 170 \\ \text { 27-Aug-85 } & 1335 & 0900 & 10.4 & 15.7 & 163 \\ \text { 31-Aug-85 } & 1339 & & 10.5 & 17.5 & 184 \\ & & & & & \\ \text { 9-Sep-85 } & 1348 & 0958 & 10.7 & 21.5 & 230 \\ \text { 17-Sep-85 } & 1356 & 0958 & 10.8 & 16.2 & 175 \\ \text { 23-Sep-85 } & 1362 & 1511 & 10.4 & 16.2 & 168 \\ \text { 30-Sep-85 } & 1369 & & 11.0 & 16.3 & 178\end{array}$

Water year 1986:

\begin{tabular}{llllll} 
8-Oct-85 & 1377 & 1652 & 11.6 & 16.4 & 190 \\
21-Oct-85 & 1390 & 0944 & 11.1 & 14.7 & 163 \\
30-Oct-85 & 1399 & 0900 & 11.7 & 16.1 & 188 \\
31-Oct-85 & 1400 & & 11.6 & 15.9 & 185 \\
4-Nov-85 & 1404 & 1043 & 11.4 & 15.2 & 174 \\
& & & & & \\
30-Nov-85 & 1430 & & 12.3 & 13.9 & 171 \\
4-Dec-85 & 1434 & 1010 & 12.4 & 13.7 & 170 \\
11-Dec-85 & 1441 & 1030 & 13.6 & 11.6 & 158 \\
31-Dec-85 & 1461 & & 13.2 & 13.2 & 174 \\
4-Jan-86 & 1465 & 1010 & 13.1 & 13.5 & 177 \\
\hline & & & & & \\
23-Jan-86 & 1484 & 1000 & 13.5 & 11.4 & 154 \\
31-Jan-86 & 1492 & & 13.2 & 11.9 & 157 \\
3-Feb-86 & 1495 & 1525 & 13.1 & 12.0 & 158 \\
28-Feb-86 & 1520 & & 12.8 & 13.7 & 176 \\
4-Mar-86 & 1524 & 0904 & 12.8 & 14.0 & 179 \\
\hline & & & & & \\
19-Mar-86 & 1539 & 0925 & 12.6 & 14.0 & 176 \\
31-Mar-86 & 1551 & 1030 & 9.0 & 29.3 & 264 \\
14-Apr-86 & 1565 & 1650 & 7.6 & 34.8 & 264 \\
16-Apr-86 & 1567 & 0945 & 8.0 & 33.8 & 270 \\
30-Apr-86 & 1581 & 0948 & 5.9 & 30.9 & 182 \\
\hline 14-May-86 & 1595 & 0955 & 7.7 & 32.5 & 250 \\
19-May-86 & 1600 & 1053 & 6.5 & 48.5 & 315 \\
26-May-86 & 1607 & 2025 & 4.0 & 91.5 & 366 \\
29-May-86 & 1610 & 0930 & 2.6 & 103.9 & 270 \\
31-May-86 & 1612 & & 2.5 & 119.2 & 292 \\
18-Aug-86 & 1691 & 0927 & 8.4 & 23.0 & 193
\end{tabular}

\begin{tabular}{lcccc}
\hline Day & Date 1 & Time 2 & \multicolumn{3}{c}{ Instantaneous values } \\
\cline { 2 - 5 } month- & No. & Chloride & Discharge & $\mathrm{Cl} \mathrm{fhux}$ \\
year & & $\mathrm{mg} / \mathrm{L}$ & $\mathrm{m}^{3} / \mathrm{s}$ & $\mathrm{g} / \mathrm{s}$ \\
\hline
\end{tabular}

\section{Falls River}

$\begin{array}{lrrrrr}\text { 27-Aug-86 } & 1700 & 0840 & 8.8 & 21.5 & 189 \\ \text { 31-Aug-86 } & 1704 & & 8.3 & 22.9 & 191 \\ \text { 2-Sep-86 } & 1706 & 0932 & 8.1 & 23.6 & 191 \\ \text { 16-Sep-86 } & 1720 & 1030 & 9.5 & 18.7 & 178 \\ \text { 29-Sep-86 } & 1733 & 0944 & 10.7 & 18.4 & 197 \\ \text { 30-Sep-86 } & 1734 & & 10.7 & 18.4 & 197\end{array}$

Water year 1987:

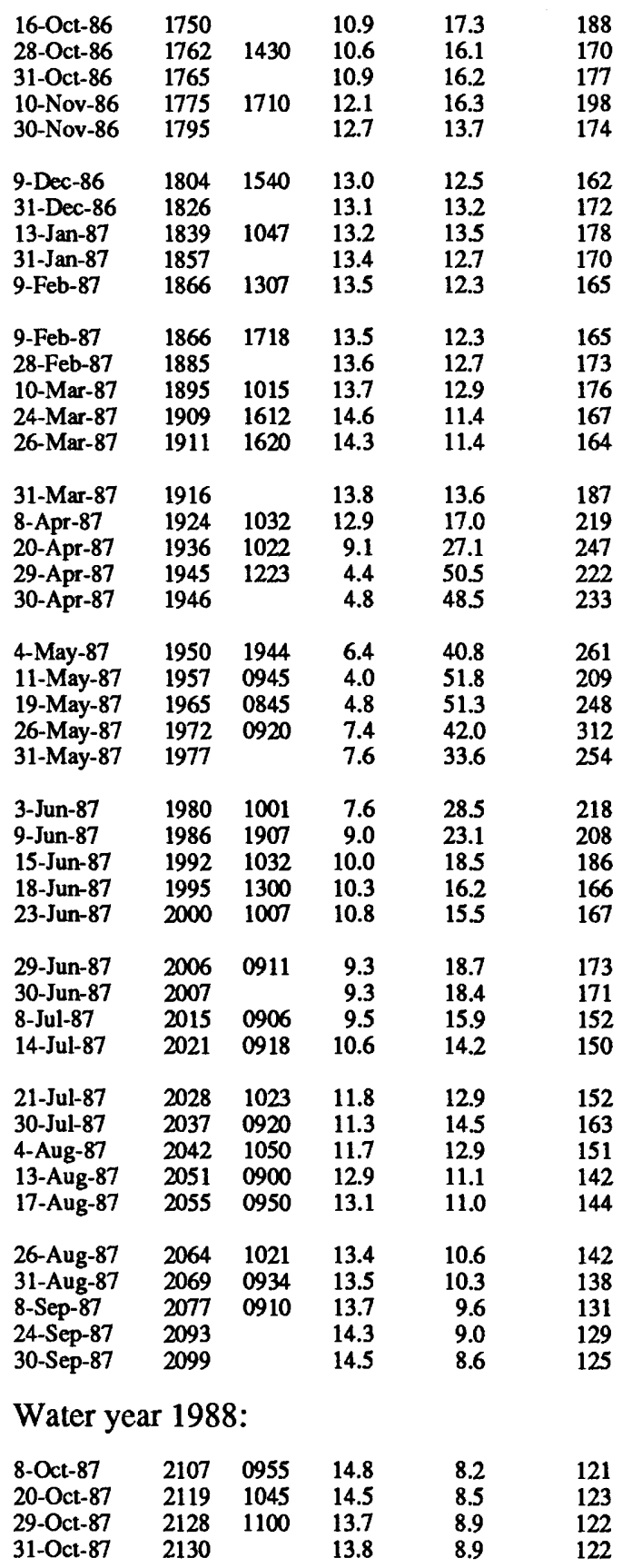




\begin{tabular}{|c|c|c|c|c|c|c|c|c|c|c|c|}
\hline \multirow{2}{*}{$\begin{array}{l}\text { Day- } \\
\text { month- } \\
\text { year } \\
\end{array}$} & \multirow{2}{*}{\multicolumn{2}{|c|}{$\begin{array}{l}\text { Date } 1 \text { Time } 2 \\
\text { No. }\end{array}$}} & \multicolumn{3}{|c|}{ Instantaneous values } & \multirow{2}{*}{$\begin{array}{l}\text { Day I } \\
\text { month- } \\
\text { year }\end{array}$} & \multirow{2}{*}{$\begin{array}{c}\text { Date } 1 \\
\text { No. }\end{array}$} & \multirow{2}{*}{ Time $\frac{2}{c}$} & \multicolumn{3}{|c|}{ Instantaneous values } \\
\hline & & & $\begin{array}{l}\text { Chloride } \\
\mathrm{mg} / \mathrm{L}\end{array}$ & $\begin{array}{c}\text { Discharge } \\
\mathrm{m}^{3} 3 \mathrm{~s}\end{array}$ & $\begin{array}{c}\mathrm{Cl} \text { flux } \\
\mathrm{g} / \mathrm{s}\end{array}$ & & & & $\begin{array}{l}\text { loride } \\
\mathrm{ng} / \mathrm{L}\end{array}$ & $\begin{array}{l}\text { Discharge } \\
\mathrm{m}^{3 / \mathrm{s}}\end{array}$ & $\begin{array}{c}\mathrm{Cl} \text { flux } \\
\mathrm{g} / \mathrm{s}\end{array}$ \\
\hline \multicolumn{6}{|c|}{ Falls River } & \multicolumn{6}{|c|}{ Falls River } \\
\hline 30-Nov-87 & 2160 & 1310 & 15.9 & 8.5 & 135 & $\begin{array}{l}\text { 12-May-89 } \\
17-\text { May-89 }\end{array}$ & $\begin{array}{l}2689 \\
2694\end{array}$ & $\begin{array}{l}1043 \\
1038\end{array}$ & $\begin{array}{l}3.9 \\
4.0\end{array}$ & $\begin{array}{l}88.9 \\
76.0\end{array}$ & $\begin{array}{l}342 \\
307\end{array}$ \\
\hline 28-Dec-87 & 2188 & 1655 & 16.3 & 10.1 & 164 & 23-May-89 & 2700 & 0918 & 3.3 & 73.6 & 244 \\
\hline 31-Dec-87 & 2191 & & 16.1 & 10.0 & 161 & 31-May-89 & 2708 & 1022 & 4.4 & 55.6 & 244 \\
\hline 12-Jan-88 & 2203 & 1130 & 15.5 & 9.5 & 147 & 31-May-89 & 2708 & & 4.6 & 54.4 & 251 \\
\hline 26-Jan-88 & 2217 & 1722 & 16.2 & 7.8 & 126 & 6-Jun-89 & 2714 & 1327 & 3.0 & 82.1 & 245 \\
\hline 31-Jan-88 & 2222 & & 16.1 & 8.0 & 129 & 14-Jun-89 & 2722 & 0917 & 3.1 & 68.8 & 212 \\
\hline 22-Feb-88 & 2244 & 1745 & 16.0 & 9.1 & 145 & 21-Jun-89 & 2729 & 0840 & 3.7 & 62.9 & 232 \\
\hline 24-Feb-88 & 2246 & 1145 & 16.0 & 9.3 & 150 & 27-Jun-89 & 2735 & 0850 & 4.6 & 40.1 & 186 \\
\hline 29-Feb-88 & 2251 & & 16.1 & 9.0 & 145 & 30-Jun-89 & 2738 & & 5.0 & 36.3 & 181 \\
\hline 15-Mar-88 & 2266 & 1150 & 16.5 & 8.0 & 131 & 4-Jul-89 & 2742 & 1040 & 5.5 & 31.2 & 171 \\
\hline 28-Mar-88 & 2279 & 1010 & 16.5 & 8.0 & 131 & 11-Jul-89 & 2749 & 0907 & 7.9 & 21.5 & 169 \\
\hline 31-Mar-88 & 2282 & & 15.8 & 9.3 & 147 & 12-Jul-89 & 2750 & 1000 & 7.9 & 20.8 & 164 \\
\hline 8-Apr-88 & 2290 & 1100 & 14.0 & 12.9 & 180 & 18-Jul-89 & 2756 & 0845 & 8.0 & 20.8 & 166 \\
\hline 13-Âpr-88 & 2295 & 1110 & 12.3 & 17.7 & 218 & 27-Jul-89 & 2765 & 0954 & 8.1 & 20.2 & 163 \\
\hline 25-Apr-88 & 2307 & 1645 & 10.0 & 31.1 & 311 & 31-Jul-89 & 2769 & & 8.4 & 18.9 & 158 \\
\hline 30-Apr-88 & 2312 & & 9.1 & 34.2 & 312 & 1-Aug-89 & 2770 & 0841 & 8.5 & 18.5 & 157 \\
\hline 11-May-88 & 2323 & 1017 & 7.2 & 41.1 & 296 & 8-Aug-89 & 2777 & 1000 & 9.2 & 17.0 & 157 \\
\hline 16-May-88 & 2328 & 1035 & 4.4 & 56.1 & 248 & 17-Aug-89 & 2786 & 0940 & 9.6 & 16.7 & 159 \\
\hline 17-May-88 & 2329 & & 4.5 & 66.3 & 298 & 23-Aug-89 & 2792 & 0905 & 9.0 & 16.7 & 150 \\
\hline 23-May-88 & 2335 & 0904 & 3.6 & 59.3 & 215 & 27-Aug-89 & 2796 & 0935 & 10.2 & 17.0 & 172 \\
\hline 31-May-88 & 2343 & & 4.8 & 35.0 & 167 & 31-Aug-89 & 2800 & & 10.3 & 16.6 & 170 \\
\hline 1-Jun-88 & 2344 & 0835 & 4.9 & 32.0 & 157 & 11-Sep-89 & 2811 & 0930 & 10.5 & 15.7 & 165 \\
\hline 6-Jun-88 & 2349 & 0925 & 3.3 & 63.2 & 210 & 27-Sep-89 & 2827 & 0914 & 10.7 & 14.4 & 155 \\
\hline 14-Jun-88 & 2357 & 0935 & 6.2 & 31.0 & 192 & 30-Sep-89 & 2830 & & 10.9 & 14.6 & 159 \\
\hline 20-Jun-88 & 2363 & 0953 & 6.6 & 25.7 & 170 & $10-$ Oct-89 & 2840 & 0938 & 11.3 & 15.1 & 171 \\
\hline 27-Jun-88 & 2370 & 0905 & 9.8 & 16.8 & 165 & & & & & & \\
\hline $\begin{array}{l}\text { 29-Jun-88 } \\
\text { 30-Jun-88 }\end{array}$ & $\begin{array}{l}2372 \\
2373\end{array}$ & 1200 & $\begin{array}{l}9.5 \\
9.5\end{array}$ & $\begin{array}{l}16.2 \\
16.5\end{array}$ & $\begin{array}{l}154 \\
157\end{array}$ & \multicolumn{6}{|c|}{ Firehole River } \\
\hline 5-Jul-88 & 2378 & 0900 & 9.6 & 18.1 & 173 & \multirow{3}{*}{\multicolumn{3}{|c|}{ Water year 1984: }} & & & \\
\hline 10-Jul-88 & 2383 & 2040 & 8.6 & 19.5 & 167 & & & & & & \\
\hline 20-Jul-88 & 2393 & 1055 & 9.2 & 17.7 & 163 & & & & & & \\
\hline 27-Jul-88 & 2400 & 2002 & 9.4 & 16.8 & 158 & $\begin{array}{l}\text { 30-Sep-83 } \\
\text { 9-Oct-83 }\end{array}$ & 638 & & $\begin{array}{l}59.8 \\
607\end{array}$ & $\begin{array}{r}15.5 \\
90\end{array}$ & 925 \\
\hline 31-Jul-88 & 2404 & & 9.6 & 15.7 & 150 & $\begin{array}{l}\text { 9-Oct-83 } \\
23-\text { Oct-83 }\end{array}$ & 647 & 1730 & 60.7 & 9.9 & 602 \\
\hline 1-Aug-88 & 2405 & 1110 & 9.6 & 15.5 & 148 & $\begin{array}{l}23-\text { Oct- } 83 \\
31-\text { Oct-83 }\end{array}$ & 661 & 1105 & $\begin{array}{l}60.1 \\
59.5\end{array}$ & $\begin{array}{r}9.4 \\
100\end{array}$ & $\begin{array}{l}565 \\
595\end{array}$ \\
\hline 9-Aug-88 & 2413 & 1140 & 10.9 & 11.1 & 121 & $\begin{array}{l}31-\text { Uct-83 } \\
6-\text { Nov-83 }\end{array}$ & $\begin{array}{l}669 \\
675\end{array}$ & 1230 & $\begin{array}{l}59.5 \\
59.0\end{array}$ & $\begin{array}{l}10.0 \\
10.4\end{array}$ & $\begin{array}{l}595 \\
616\end{array}$ \\
\hline 10 -Aug-88 & 2414 & 0718 & 11.0 & 11.4 & 126 & $0-1$ NoV-83 & & & & & 010 \\
\hline & & & & & & 30-Nov-83 & 699 & & 64.9 & 9.0 & 585 \\
\hline 17-Aug-88 & 2421 & 0748 & 11.5 & 12.5 & 143 & 4-Dec-83 & 703 & 1215 & 65.9 & 8.8 & 578 \\
\hline 22-Aug-88 & 2426 & 0950 & 11.6 & 12.1 & 141 & 31-Dec-83 & 730 & & 66.0 & 8.5 & 564 \\
\hline 30-Aug-88 & 2434 & 0730 & 12.1 & 11.4 & 138 & 1-Jan-84 & 731 & 1330 & 66.1 & 8.5 & 563 \\
\hline 31-Aug-88 & 2435 & & 12.1 & 11.3 & 138 & 29-Jan-84 & 759 & 1130 & 67.9 & 8.2 & 559 \\
\hline 6-Sep-88 & 2441 & 1009 & 12.4 & 10.8 & 134 & & & & & & \\
\hline 20-Sep-88 & & 1015 & 12.5 & & & 31-Jan-84 & 761 & & 68.0 & 8.2 & $\begin{array}{l}559 \\
555\end{array}$ \\
\hline $30-$ Sep-88 & 2465 & & $\begin{array}{l}12.3 \\
12.6\end{array}$ & $\begin{array}{l}11.8 \\
11.0\end{array}$ & $\begin{array}{l}147 \\
138\end{array}$ & 29-Feb-84 & 790 & 1145 & 70.7 & $\begin{array}{l}7.8 \\
8.3\end{array}$ & $\begin{array}{l}555 \\
611\end{array}$ \\
\hline \multirow{2}{*}{\multicolumn{6}{|c|}{ Water year 1989: }} & $\begin{array}{l}\text { 16-Mar-84 } \\
\text { 29-Mar-84 }\end{array}$ & $\begin{array}{l}806 \\
819\end{array}$ & $\begin{array}{l}1130 \\
1340\end{array}$ & $\begin{array}{l}73.4 \\
71.2\end{array}$ & $\begin{array}{l}8.3 \\
8.1\end{array}$ & 575 \\
\hline & & & & & & 31-Mar-84 & 821 & & 71.1 & 8.1 & 575 \\
\hline 13-Jan-89 & 2570 & 1030 & 16.6 & 8.8 & 146 & 10-Apr-84 & 831 & 1400 & 70.6 & 8.1 & 574 \\
\hline 31-Jan-89 & 2588 & & 17.3 & 9.2 & 159 & 25-Apr-84 & 846 & 1100 & 64.8 & 9.1 & 591 \\
\hline 8-Feb-89 & 2596 & 1535 & 17.6 & 9.3 & 164 & 30-Apr-84 & 851 & & 66.8 & 9.1 & 609 \\
\hline 28-Feb-89 & 2616 & & 16.5 & 8.9 & 147 & 3-May-84 & 854 & 1420 & 68.1 & 9.1 & 621 \\
\hline 6-Mar-89 & 2622 & 1430 & 16.2 & 8.8 & 142 & 9-May-84 & 860 & 1045 & 66.4 & 9.1 & 606 \\
\hline 9-Mar-89 & 2625 & 0917 & 15.7 & 10.8 & 170 & 17-May-84 & 868 & 1230 & 39.8 & 15.5 & 619 \\
\hline 21-Mar-89 & 2637 & 1645 & 16.1 & 9.2 & 148 & 23-May-84 & 874 & 0900 & 30.1 & 18.5 & $\begin{array}{l}019 \\
557\end{array}$ \\
\hline 31-Mar-89 & 2647 & & 16.2 & 8.7 & 142 & $\begin{array}{l}\text { 20-10ay-o4 } \\
\text { 30-May-84 }\end{array}$ & 881 & 1540 & 31.8 & 18.9 & $\begin{array}{l}531 \\
602\end{array}$ \\
\hline 6-Apr-89 & 2653 & 0955 & 16.3 & 8.5 & 138 & $\begin{array}{l}\text { 30-May-84 } \\
\text { 31-May-84 }\end{array}$ & 882 & & 33.9 & 18.4 & 602 \\
\hline 18-Âpr-89 & 2665 & 1020 & 11.8 & 19.0 & 224 & 31-May-84 & 882 & & 33.9 & 18.4 & 624 \\
\hline & & & & & & 6-Jun-84 & 888 & 0620 & 46.4 & 15.3 & 710 \\
\hline $\begin{array}{l}\text { 30-Apr-89 } \\
\text { 2-May-89 }\end{array}$ & 2677 & & 9.0 & 32.2 & 291 & & & & & & \\
\hline ay-89 & 2679 & 1410 & 8.6 & 34.5 & 295 & 6-Jun-84 & 888 & 1810 & 43.2 & 15.0 & 650 \\
\hline
\end{tabular}




\begin{tabular}{lcccc}
\hline Day- & Date 1 & Time 2 & \multicolumn{3}{c}{ Instantaneous } & values \\
\cline { 3 - 5 } month- & No. & Chloride & Discharge & Cl flux \\
year & & $\mathrm{mg} / \mathrm{L}$ & $\mathrm{m} 3 / \mathrm{s}$ & $\mathrm{g} / \mathrm{s}$
\end{tabular}

Firehole River

\begin{tabular}{|c|c|c|c|c|c|}
\hline 13-Jun-84 & 895 & 1450 & 44.6 & 13.6 & 609 \\
\hline 20-Jun-84 & 902 & 1250 & 37.0 & 15.1 & 557 \\
\hline 28-Jun-84 & 910 & 2000 & 42.7 & 12.2 & 521 \\
\hline 30-Jun-84 & 912 & & 45.1 & 11.6 & 524 \\
\hline 5-Jul-84 & 917 & 1940 & 50.9 & 10.2 & 518 \\
\hline 11-Jul-84 & 923 & 1010 & 56.9 & 9.7 & 551 \\
\hline 19-Jul-84 & 931 & 1540 & 58.7 & 9.3 & 547 \\
\hline 25-Jul-84 & 937 & 1240 & 56.9 & 9.5 & 539 \\
\hline 31-Jul-84 & 943 & & 58.9 & 9.7 & 569 \\
\hline 1-Aug-84 & 944 & 1210 & 59.3 & 9.7 & 574 \\
\hline 9-Aug-84 & 952 & 0845 & 59.9 & 8.9 & 536 \\
\hline 16-Aug-84 & 959 & 1445 & 58.7 & 11.8 & 532 \\
\hline 22-Aug-84 & 965 & 1413 & 59.7 & 9.1 & 545 \\
\hline 30-Aug-84 & 973 & 1430 & 60.5 & 9.0 & 547 \\
\hline 31-Aug-84 & 974 & & 60.5 & 9.0 & 47 \\
\hline 11-Sep-84 & 985 & 1530 & 59.7 & 9.2 & 550 \\
\hline 26-Sep-84 & 1000 & 1120 & 63.1 & 9.2 & \\
\hline 30-Sep-84 & 1004 & & 62.7 & 9.1 & 5 \\
\hline
\end{tabular}

Water year 1985:

$\begin{array}{llllll}\text { 12-Oct-84 } & 1016 & 1200 & 61.3 & 8.9 & 548 \\ \text { 26-Oct-84 } & 1030 & 1436 & 62.8 & 9.1 & 572 \\ \text { 31-Oct-84 } & 1035 & & 63.5 & 9.1 & 581 \\ \text { 9-Nov-84 } & 1044 & 1400 & 64.8 & 9.2 & 596 \\ \text { 30-Nov-84 } & 1065 & & 65.1 & 8.7 & 565 \\ & & & & & \\ \text { 7-Dec-84 } & 1072 & 1520 & 65.2 & 8.5 & 554 \\ \text { 31-Dec-84 } & 1096 & & 67.2 & 8.7 & 583 \\ \text { 2-Jan-85 } & 1098 & 1240 & 67.3 & 8.7 & 585 \\ \text { 23-Jan-85 } & 1119 & 1450 & 66.9 & 8.1 & 540 \\ \text { 31-Jan-85 } & 1127 & & 67.1 & 8.0 & 537 \\ & & & & & \\ \text { 21-Feb-85 } & 1148 & 0745 & 67.5 & 7.8 & 527 \\ \text { 21-Feb-85 } & 1148 & 1820 & 70.6 & 8.0 & 564 \\ \text { 28-Feb-85 } & 1155 & & 70.5 & 7.9 & 559 \\ \text { 14-Mar-85 } & 1169 & 0630 & 70.3 & 7.8 & 550 \\ \text { 31-Mar-85 } & 1186 & & 59.3 & 9.9 & 588 \\ & & & & & \\ \text { 17-Apr-85 } & 1203 & 1000 & 48.3 & 12.0 & 580 \\ \text { 30-Apr-85 } & 1216 & & 46.3 & 12.1 & 561 \\ \text { 31-May-85 } & 1247 & & 41.6 & 12.3 & 513 \\ \text { 11-Jun-85 } & 1258 & 1630 & 39.9 & 12.4 & 496 \\ \text { 30-Jun-85 } & 1277 & & 45.9 & 12.5 & 574 \\ \text { 23-Jul-85 } & 1300 & 1450 & 53.1 & 12.6 & 670 \\ \text { 31-Jul-85 } & 1308 & & 56.3 & 11.8 & 665 \\ \text { 31-Aug-85 } & 1339 & & 68.6 & 8.7 & 599 \\ \text { 4-Sep-85 } & 1343 & 1700 & 70.2 & 8.3 & 585 \\ \text { 30-Sep-85 } & 1369 & & 66.8 & 8.7 & 578 \\ & & & & & \end{array}$

Water year 1986:

$\begin{array}{llllll}\text { 16-Oct-85 } & 1385 & 1500 & 64.7 & 40.2 & 573 \\ \text { 31-Oct-85 } & 1400 & & 66.0 & 42.0 & 612 \\ \text { 8-Nov-85 } & 1408 & 0925 & 66.7 & 43.0 & 633 \\ \text { 30-Nov-85 } & 1430 & & 67.0 & 40.3 & 596 \\ \text { 5-Dec-85 } & 1435 & 1630 & 67.1 & 39.6 & 587 \\ & & & & & \\ \text { 31-Dec-85 } & 1461 & & 68.5 & 39.0 & 589 \\ \text { 3-Jan-86 } & 1464 & 1450 & 68.7 & 38.9 & 590 \\ \text { 31-Jan-86 } & 1492 & & 71.4 & 38.5 & 607 \\ \text { 3-Feb-86 } & 1495 & 1435 & 71.6 & 38.5 & 609 \\ \text { 5-Feb-86 } & 1497 & 1120 & 70.2 & 37.3 & 579 \\ \text { 28-Feb-86 } & 1520 & & 71.7 & 40.3 & 637\end{array}$

Day Date 1 Time 2 Instantaneous values month- No. Chloride Discharge Cl flux year

$\mathrm{m}^{3 / \mathrm{s}}$

g/s

\section{Firehole River}

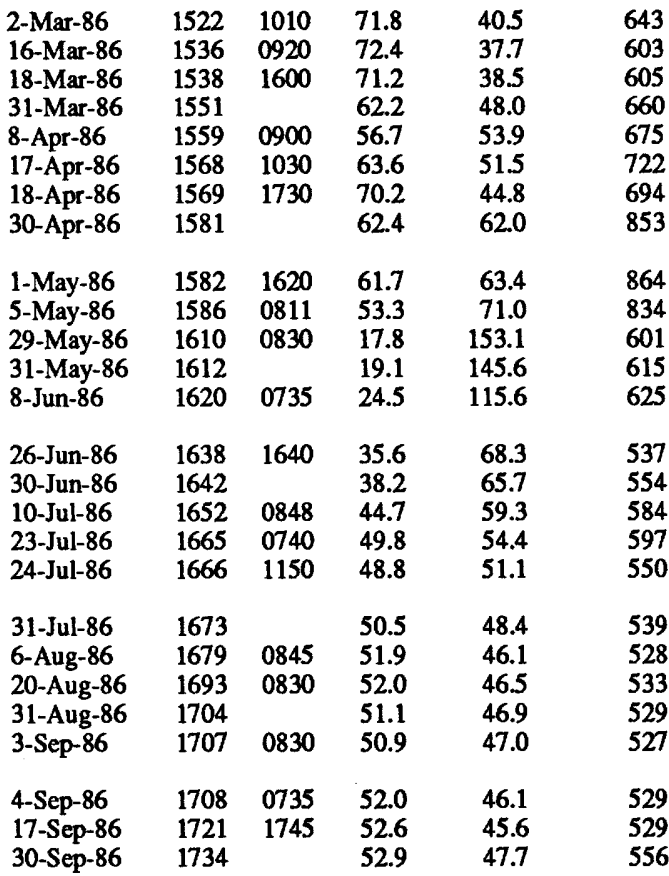

Water year 1987:

$\begin{array}{llllll}\text { 1-Oct-86 } & 1735 & 0804 & 52.9 & 10.6 & 558 \\ \text { 8-Oct-86 } & 1742 & 1100 & 52.4 & 9.9 & 518 \\ \text { 15-Oct-86 } & 1749 & 1135 & 53.5 & 9.3 & 498 \\ \text { 25-Oct-86 } & 1759 & 1605 & 53.2 & 9.7 & 515 \\ \text { 31-Oct-86 } & 1765 & & 58.4 & 9.6 & 559 \\ & & & & & \\ \text { 18-Nov-86 } & 1783 & 1100 & 63.1 & 9.3 & 588 \\ \text { 27-Nov-86 } & 1792 & 1112 & 59.4 & 9.0 & 537 \\ \text { 30-Nov-86 } & 1795 & & 59.6 & 8.9 & 528 \\ \text { 10-Dec-86 } & 1805 & 1200 & 60.0 & 8.3 & 500 \\ \text { 24-Dec-86 } & 1819 & 1150 & 58.5 & 8.5 & 497 \\ & & & 60.3 & 8.5 & 512 \\ \text { 31-Dec-86 } & 1826 & & 65 & 544 \\ \text { 6-Jan-87 } & 1832 & 1300 & 63.4 & 8.6 & 528 \\ \text { 7-Jan-87 } & 1833 & 1437 & 62.2 & 8.5 & 539 \\ \text { 21-Jan-87 } & 1847 & 1230 & 66.8 & 8.1 & 543 \\ \text { 31-Jan-87 } & 1857 & & 64.8 & 8.4 & \\ & & & & & 544 \\ \text { 4-Feb-87 } & 1861 & 1555 & 64.0 & 8.5 & 547 \\ \text { 18-Feb-87 } & 1875 & 0937 & 67.0 & 8.2 & 539 \\ \text { 18-Feb-87 } & 1875 & 1100 & 66.1 & 8.2 & 576 \\ \text { 28-Feb-87 } & 1885 & & 68.7 & 8.4 & 576 \\ \text { 11-Mar-87 } & 1896 & 1000 & 71.5 & 8.7 & 620 \\ \text { 25-Mar-87 } & 1910 & 1545 & 68.6 & 8.0 & 548 \\ \text { 31-Mar-87 } & 1916 & & 67.8 & 7.9 & 534 \\ \text { 3-Apr-87 } & 1919 & 0900 & 67.4 & 7.8 & 527 \\ \text { 8-Apr-87 } & 1924 & 1347 & 62.1 & 8.7 & 538 \\ \text { 23-Apr-87 } & 1939 & 1712 & 50.4 & 10.2 & 512 \\ & & & & & \\ \text { 30-Apr-87 } & 1946 & & 48.9 & 11.0 & 517 \\ \text { 6-May-87 } & 1952 & 0902 & 44.4 & 11.8 & 523 \\ \text { 19-May-87 } & 1965 & 0930 & 51.2 & 12.3 & 631 \\ \text { 20-May-87 } & 1966 & 0928 & 53.9 & 11.6 & 623 \\ \text { 31-May-87 } & 1977 & & 60.9 & 9.2 & 559\end{array}$




\begin{tabular}{lcccc}
\hline $\begin{array}{l}\text { Day- } \\
\text { month- }\end{array}$ & $\begin{array}{c}\text { Date 1 } \\
\text { year }\end{array}$ & No. & \multicolumn{3}{c}{ Instantaneous values } \\
\cline { 2 - 4 } \cline { 2 - 4 } & & $\begin{array}{c}\text { Chloride } \\
\mathrm{mg} / \mathrm{L}\end{array}$ & $\begin{array}{c}\text { Discharge } \\
\text { y/s }\end{array}$ & $\begin{array}{c}\mathrm{Cl} \text { flux } \\
\mathrm{g} / \mathrm{s}\end{array}$ \\
\hline \multicolumn{4}{c}{ Firehole River } \\
\hline
\end{tabular}

$\begin{array}{llllll}\text { 4-Jun-87 } & 1981 & 1727 & 63.4 & 8.3 & \mathbf{5 2 8} \\ \text { 17-Jun-87 } & 1994 & 1725 & 68.6 & 7.6 & 524 \\ \text { 30-Jun-87 } & 2007 & 1145 & 64.8 & 7.5 & 484 \\ \text { 1-Jul-87 } & 2008 & 1727 & 67.6 & 7.4 & 500 \\ \text { 15-Jul-87 } & 2022 & 1229 & 67.8 & 7.2 & 490 \\ \text { 26-Jul-87 } & 2033 & 1800 & 68.4 & 7.5 & 511 \\ \text { 31-Jul-87 } & 2038 & & 68.8 & 7.4 & 506 \\ \text { 12-Aug-87 } & 2050 & 1725 & 69.7 & 7.1 & 494 \\ & & & & & \\ \text { 18-Aug-87 } & 2056 & 1220 & 69.6 & 7.2 & 498 \\ \text { 26-Aug-87 } & 2064 & 1645 & 67.8 & 7.2 & 491 \\ \text { 31-Aug-87 } & 2069 & & 68.4 & 7.1 & 488 \\ \text { 9-Sep-87 } & 2078 & 1510 & 69.6 & 6.9 & 481 \\ \text { 23-Sep-87 } & 2092 & 1729 & 71.0 & 6.7 & 475 \\ & & & & & \\ \text { 30-Sep-87 } & 2099 & & 71.1 & 6.8 & 484\end{array}$

Water year 1988:

$\begin{array}{llllll}\text { 6-Oct-87 } & 2105 & 1205 & 71.2 & 6.9 & 492 \\ \text { 7-Oct-87 } & 2106 & 1734 & 72.0 & 7.0 & 503 \\ \text { 21-Oct-87 } & 2120 & 1530 & 73.1 & 6.8 & 499 \\ \text { 31-Oct-87 } & 2130 & & 72.4 & 6.9 & 499 \\ \text { 4-Nov-87 } & 2134 & 1030 & 72.2 & 6.9 & 499 \\ & & & & & \\ \text { 17-Nov-87 } & 2147 & 1130 & 72.9 & 6.8 & 497 \\ \text { 30-Nov-87 } & 2160 & & 74.6 & 6.7 & 499 \\ \text { 1-Dec-87 } & 2161 & 0837 & 74.8 & 6.7 & 500 \\ \text { 30-Dec-87 } & 2190 & 1445 & 77.5 & 6.9 & 536 \\ \text { 31-Dec-87 } & 2191 & & 77.5 & 6.9 & 536 \\ \text { 5-Jan-88 } & 2196 & 1120 & 77.3 & 7.0 & 541 \\ \text { 28-Jan-88 } & 2219 & 1303 & 80.5 & 7.2 & 577 \\ \text { 31-Jan-88 } & 2222 & & 80.6 & 7.1 & 574 \\ \text { 17-Feb-88 } & 2239 & 1210 & 81.1 & 6.9 & 560 \\ \text { 24-Feb-88 } & 2246 & 1328 & 73.7 & 6.9 & 509 \\ & & & & & \\ \text { 29-Feb-88 } & 2251 & & 75.2 & 6.9 & 518 \\ \text { 16-Mar-88 } & 2267 & 0856 & 79.9 & 6.8 & 545 \\ \text { 29-Mar-88 } & 2280 & 1130 & 73.1 & 7.2 & 524 \\ \text { 31-Mar-88 } & 2282 & 1201 & 80.5 & 6.9 & 556 \\ \text { 13-Apr-88 } & 2295 & 1726 & 66.2 & 9.9 & 654 \\ \text { 21-Apr-88 } & 2303 & 1740 & 59.9 & 10.4 & 621 \\ \text { 27-Apr-88 } & 2309 & 1709 & 74.3 & 9.9 & 734 \\ \text { 30-Apr-88 } & 2312 & & 72.5 & 9.4 & 682 \\ \text { 4-May-88 } & 2316 & 1705 & 70.2 & 8.7 & 614 \\ \text { 12-May-88 } & 2324 & 1544 & 51.2 & 11.0 & 565 \\ & & & & & \\ \text { 17-May-88 } & 2329 & 1130 & 30.6 & 16.9 & 518 \\ \text { 18-May-88 } & 2330 & 1709 & 37.5 & 14.1 & 529 \\ \text { 25-May-88 } & 2337 & 1709 & 38.9 & 12.7 & 496 \\ \text { 31-May-88 } & 2343 & & 50.5 & 10.8 & 544 \\ \text { 1-Jun-88 } & 2344 & 1714 & 52.4 & 10.4 & 548 \\ & & & & & \\ \text { 8-Jun-88 } & 2351 & 1846 & 54.9 & 8.7 & 480 \\ \text { 15-Jun-88 } & 2358 & 1713 & 66.5 & 7.4 & 491 \\ \text { 22-Jun-88 } & 2365 & 1049 & 70.0 & 7.1 & 496 \\ \text { 22-Jun-88 } & 2365 & 1210 & 69.0 & 7.1 & 488 \\ \text { 29-Jun-88 } & 2372 & 0715 & 72.8 & 6.7 & 487 \\ \text { 30-Jun-88 } & 2373 & & 72.6 & 6.6 & 482 \\ \text { 6-JuI-88 } & 2379 & 0734 & 71.6 & 6.4 & 456 \\ \text { 13-Jul-88 } & 2386 & 0845 & 76.0 & 6.3 & 480 \\ \text { 20-Jul-88 } & 2393 & 0748 & 76.9 & 6.1 & 468 \\ \text { 27-Jul-88 } & 2400 & 0741 & 77.5 & 6.2 & 483 \\ & & & & & \end{array}$

\begin{tabular}{lcccc}
\hline Day & Date 1 & Time 2 & \multicolumn{3}{c}{ Instantaneous values } \\
\cline { 2 - 5 } $\begin{array}{l}\text { month- } \\
\text { year }\end{array}$ & No. & Chloride & Discharge & $\mathrm{Cl} \mathrm{flux}$ \\
& & $\mathrm{mg} / \mathrm{L}$ & $\mathrm{m} 3 / \mathrm{s}$ & $\mathrm{g} / \mathrm{s}$ \\
\hline
\end{tabular}

\section{Firehole River}

$\begin{array}{llllll}\text { 31-Jul-88 } & 2404 & & 77.0 & 6.1 & 474 \\ \text { 3-Aug-88 } & 2407 & 0726 & 76.7 & 6.1 & 467 \\ \text { 9-Aug-88 } & 2413 & 1215 & 78.6 & 6.1 & 481 \\ \text { 9-Aug-88 } & 2413 & 1715 & 77.6 & 6.1 & 472 \\ \text { 17-Aug-88 } & 2421 & 917 & 76.4 & 5.9 & 454 \\ \text { 24-Aug-88 } & 2428 & 0915 & 75.6 & 6.1 & 458 \\ \text { 31-Aug-88 } & 2435 & 1659 & 78.4 & 6.0 & 471 \\ \text { 7-Sep-88 } & 2442 & 1827 & 78.8 & 5.9 & 469 \\ \text { 20-Sep-88 } & 2455 & 1215 & 79.1 & 6.3 & 499 \\ & & & & & \\ \text { 21-Sep-88 } & 2456 & 1712 & 76.5 & 6.3 & 483 \\ \text { 30-Sep-88 } & 2465 & & 76.3 & 6.3 & 478\end{array}$

Water year 1989:

\begin{tabular}{|c|c|c|c|c|c|}
\hline $\begin{array}{l}\text { 30-Sep-88 } \\
\text { 21-Sep-88 } \\
30-\text { Sep-88 } \\
5-\text { Oct-88 } \\
6-\text { Oct-88 }\end{array}$ & $\begin{array}{l}638 \\
2456 \\
2465 \\
2470 \\
2471\end{array}$ & $\begin{array}{l}1712 \\
1702 \\
1230\end{array}$ & $\begin{array}{l}53.1 \\
76.5 \\
76.3 \\
76.2 \\
77.5\end{array}$ & $\begin{array}{l}2.8 \\
6.3 \\
6.5 \\
6.5 \\
6.5\end{array}$ & $\begin{array}{l}150 \\
483 \\
493 \\
498 \\
500\end{array}$ \\
\hline $\begin{array}{l}\text { 19-Oct-88 } \\
\text { 31-Oct-88 } \\
\text { 3-Nov-88 } \\
\text { 16-Nov-88 } \\
\text { 30-Nov-88 }\end{array}$ & $\begin{array}{l}2484 \\
2496 \\
2499 \\
2512 \\
2526\end{array}$ & $\begin{array}{l}1754 \\
1145 \\
0901\end{array}$ & $\begin{array}{l}79.3 \\
79.8 \\
79.9 \\
85.1 \\
83.9\end{array}$ & $\begin{array}{l}6.6 \\
7.0 \\
7.1 \\
6.5 \\
6.5\end{array}$ & $\begin{array}{l}523 \\
557 \\
566 \\
549 \\
542\end{array}$ \\
\hline $\begin{array}{l}\text { 13-Dec-88 } \\
\text { 15-Dec-88 } \\
\text { 31-Dec-88 } \\
\text { 10-Jan-89 } \\
\text { 31-Jan-89 }\end{array}$ & $\begin{array}{l}2539 \\
2541 \\
2557 \\
2567 \\
2588\end{array}$ & $\begin{array}{l}1515 \\
1508 \\
1615\end{array}$ & $\begin{array}{l}82.8 \\
84.3 \\
79.1 \\
75.9 \\
83.3\end{array}$ & $\begin{array}{l}6.5 \\
5.6 \\
6.0 \\
6.3 \\
6.5\end{array}$ & $\begin{array}{l}535 \\
470 \\
477 \\
479 \\
540\end{array}$ \\
\hline $\begin{array}{l}\text { 7-Feb-89 } \\
\text { 9-Feb-89 } \\
\text { 28-Feb-89 } \\
\text { 7-Mar-89 } \\
\text { 8-Mar-89 }\end{array}$ & $\begin{array}{l}2595 \\
2597 \\
2616 \\
2623 \\
2624\end{array}$ & $\begin{array}{l}1515 \\
1015 \\
\\
0945 \\
1330\end{array}$ & $\begin{array}{l}85.7 \\
83.4 \\
86.3 \\
87.3 \\
85.4\end{array}$ & $\begin{array}{l}6.5 \\
6.4 \\
6.9 \\
7.1 \\
6.8\end{array}$ & $\begin{array}{l}561 \\
531 \\
594 \\
618 \\
583\end{array}$ \\
\hline $\begin{array}{l}\text { 23-Mar-89 } \\
\text { 31-Mar-89 } \\
\text { 4-Apr-89 } \\
\text { 19-Apr-89 } \\
\text { 30-Apr-89 }\end{array}$ & $\begin{array}{l}2639 \\
2647 \\
2651 \\
2666 \\
2677\end{array}$ & $\begin{array}{l}0910 \\
1125 \\
1750\end{array}$ & $\begin{array}{l}85.0 \\
84.3 \\
83.9 \\
60.9 \\
60.9\end{array}$ & $\begin{array}{r}6.7 \\
6.6 \\
6.5 \\
10.4 \\
10.2\end{array}$ & $\begin{array}{l}568 \\
555 \\
549 \\
636 \\
623\end{array}$ \\
\hline $\begin{array}{l}\text { 3-May-89 } \\
\text { 3-May-89 } \\
\text { 31-May-89 } \\
\text { 14-Jun-89 } \\
\text { 30-Jun-89 }\end{array}$ & $\begin{array}{l}2680 \\
2680 \\
2708 \\
2722 \\
2738\end{array}$ & $\begin{array}{r}1752 \\
1015 \\
\\
1115\end{array}$ & $\begin{array}{l}60.9 \\
56.4 \\
45.2 \\
39.6 \\
59.0\end{array}$ & $\begin{array}{r}10.2 \\
11.2 \\
12.7 \\
13.5 \\
9.3\end{array}$ & $\begin{array}{l}619 \\
629 \\
576 \\
536 \\
549\end{array}$ \\
\hline $\begin{array}{l}\text { 5-Jul-89 } \\
\text { 13-Jul-89 } \\
\text { 21-Jul-89 } \\
\text { 26-Jul-89 } \\
28-J u l-89\end{array}$ & $\begin{array}{l}2743 \\
2751 \\
2759 \\
2764 \\
2766\end{array}$ & $\begin{array}{l}0850 \\
1140 \\
1000 \\
1000 \\
1100\end{array}$ & $\begin{array}{l}65.0 \\
61.5 \\
68.9 \\
68.3 \\
67.4\end{array}$ & $\begin{array}{l}8.0 \\
8.9 \\
7.6 \\
7.6 \\
8.3\end{array}$ & $\begin{array}{l}519 \\
550 \\
521 \\
516 \\
561\end{array}$ \\
\hline $\begin{array}{l}\text { 31-Jul-89 } \\
4-\text { Aug-89 } \\
10-A u g-89 \\
12-A u g-89 \\
21-A u g-89\end{array}$ & $\begin{array}{l}2769 \\
2773 \\
2779 \\
2781 \\
2790\end{array}$ & $\begin{array}{l}1630 \\
1645 \\
1515 \\
1000\end{array}$ & $\begin{array}{l}68.0 \\
68.7 \\
71.7 \\
68.1 \\
70.3\end{array}$ & $\begin{array}{l}8.0 \\
7.6 \\
7.7 \\
7.9 \\
8.0\end{array}$ & $\begin{array}{l}546 \\
525 \\
554 \\
538 \\
561\end{array}$ \\
\hline $\begin{array}{l}\text { 27-Aug-89 } \\
\text { 31-Aug-89 } \\
\text { 12-Sep-89 } \\
\text { 26-Sep-89 } \\
\text { 30-Sep-89 }\end{array}$ & $\begin{array}{l}2796 \\
2800 \\
2812 \\
2826 \\
2830\end{array}$ & $\begin{array}{l}0930 \\
1100 \\
1308\end{array}$ & $\begin{array}{l}70.2 \\
70.4 \\
71.0 \\
71.8 \\
71.6\end{array}$ & $\begin{array}{l}7.6 \\
7.5 \\
7.2 \\
7.1 \\
7.2\end{array}$ & $\begin{array}{l}537 \\
530 \\
509 \\
508 \\
513\end{array}$ \\
\hline
\end{tabular}




\begin{tabular}{|c|c|c|c|c|}
\hline \multirow{2}{*}{$\begin{array}{l}\text { Day- } \\
\text { month- } \\
\text { year }\end{array}$} & \multirow{2}{*}{$\begin{array}{l}\text { Date } 1 \text { Time } 2 \\
\text { No. }\end{array}$} & \multicolumn{3}{|c|}{ Instantaneous values } \\
\hline & & $\begin{array}{l}\text { Chloride } \\
\mathrm{mg} / \mathrm{L}\end{array}$ & $\begin{array}{c}\text { Discharge } \\
\mathrm{m} 3 / \mathrm{s}\end{array}$ & $\begin{array}{c}\mathrm{Cl} \text { flux } \\
\mathrm{g} / \mathrm{s}\end{array}$ \\
\hline \multicolumn{5}{|c|}{ Gibbon River } \\
\hline
\end{tabular}

Water year 1984:

$\begin{array}{llllll}\text { 30-Sep-83 } & 638 & & 53.1 & 2.83 & 150 \\ \text { 15-Oct-83 } & 653 & 1750 & 47.8 & 3.20 & 153 \\ \text { 26-Oct-83 } & 664 & 1045 & 48.8 & 2.97 & 145 \\ \text { 31-Oct-83 } & 669 & & 48.4 & 2.99 & 145 \\ \text { 9-Nov-83 } & 678 & 1305 & 47.5 & 3.03 & 144 \\ & & & & & \\ \text { 30-Nov-83 } & 699 & & 56.4 & 2.94 & 166 \\ \text { 6-Dec-83 } & 705 & 1215 & 58.9 & 2.92 & 172 \\ \text { 31-Dec-83 } & 730 & & 60.1 & 2.80 & 168 \\ \text { 6-Jan-84 } & 736 & 1430 & 60.3 & 2.78 & 167 \\ \text { 25-Jan-84 } & 755 & 1715 & 64.3 & 2.44 & 156 \\ & & & & & \\ \text { 31-Jan-84 } & 761 & & 62.5 & 2.29 & 143 \\ \text { 2-Feb-84 } & 763 & 1200 & 61.9 & 2.24 & 139 \\ \text { 29-Feb-84 } & 790 & 1230 & 65.9 & 2.32 & 153 \\ \text { 14-Mar-84 } & 804 & 1140 & 70.6 & 2.24 & 158 \\ \text { 29-Mar-84 } & 819 & 1315 & 68.2 & 2.32 & 158 \\ & & & & & \\ \text { 31-Mar-84 } & 821 & & 67.9 & 2.33 & 158 \\ \text { 10-Apr-84 } & 831 & 1420 & 66.3 & 2.35 & 156 \\ \text { 25-Apr-84 } & 846 & 1130 & 40.5 & 3.43 & 139 \\ \text { 30-Apr-84 } & 851 & & 44.5 & 3.25 & 145 \\ \text { 3-May-84 } & 854 & 1440 & 46.9 & 3.14 & 148 \\ \text { 9-May-84 } & 860 & 1100 & 47.5 & 3.43 & 163 \\ \text { 17-May-84 } & 868 & 1245 & 17.5 & 10.25 & 179 \\ \text { 23-May-84 } & 874 & 0920 & 15.4 & 10.36 & 160 \\ \text { 29-May-84 } & 880 & 1300 & 18.3 & 8.47 & 155 \\ \text { 31-May-84 } & 882 & & 19.0 & 8.29 & 157 \\ \text { 6-Jun-84 } & 888 & 1245 & 21.1 & 7.76 & 163 \\ \text { 12-Jun-84 } & 894 & 0620 & 21.1 & 7.87 & 166 \\ \text { 12-Jun-84 } & 894 & 1740 & 21.1 & 7.02 & 148 \\ \text { 20-Jun-84 } & 902 & 1235 & 25.0 & 5.18 & 129 \\ \text { 28-Jun-84 } & 910 & 1940 & 29.4 & 4.28 & 126 \\ & & & & & \\ \text { 30-Jun-84 } & 912 & & 29.5 & 4.19 & 124 \\ \text { 5-Jul-84 } & 917 & 1100 & 29.7 & 3.99 & 119 \\ \text { 11-Jul-84 } & 923 & 1030 & 32.1 & 4.33 & 139 \\ \text { 19-Jul-84 } & 931 & 1600 & 34.2 & 3.99 & 137 \\ \text { 25-Jul-84 } & 937 & 1300 & 35.8 & 4.19 & 150 \\ & & & 33.1 & 4.09 & 136 \\ \text { 31-Jul-84 } & 943 & & & \\ \text { 1-Aug-84 } & 944 & 1230 & 32.7 & 4.08 & 133 \\ \text { 9-Aug-84 } & 952 & 0900 & 37.1 & 3.20 & 119 \\ \text { 16-Aug-84 } & 959 & 1500 & 44.7 & 3.79 & 170 \\ \text { 22-Aug-84 } & 965 & 1345 & 42.7 & 3.26 & 139 \\ \text { 30-Aug-84 } & 973 & 1450 & 43.6 & 3.09 & 135 \\ \text { 31-Aug-84 } & 974 & & 44.0 & 3.10 & 136 \\ \text { 11-Sep-84 } & 985 & 1545 & 48.2 & 3.26 & 157 \\ \text { 26-Sep-84 } & 1000 & & 49.5 & 3.31 & 164 \\ \text { 30-Sep-84 } & 1004 & & 49.2 & 3.02 & 149 \\ & & & & & \end{array}$

Water year 1985:

$\begin{array}{llllll}\text { 3-Oct-84 } & 1007 & 0840 & 49.0 & 2.80 & 137 \\ \text { 12-Oct-84 } & 1016 & 1220 & 52.4 & 2.66 & 139 \\ \text { 26-Oct-84 } & 1030 & 1410 & 55.0 & 2.72 & 149 \\ \text { 31-Oct-84 } & 1035 & & 56.4 & 2.77 & 156 \\ \text { 9-Nov-84 } & 1044 & 1330 & 58.9 & 2.86 & 168 \\ & & & & & \\ \text { 9-Nov-84 } & 1044 & 1100 & 60.4 & 2.78 & 168 \\ \text { 30-Nov-84 } & 1065 & & 61.0 & 2.63 & 160 \\ \text { 7-Dec-84 } & 1072 & 1550 & 61.2 & 2.58 & 158 \\ \text { 20-Dec-84 } & 1085 & 1130 & 64.5 & 2.44 & 157\end{array}$

\begin{tabular}{lcccc}
\hline Day & Date 1 & Time 2 & \multicolumn{3}{c}{ Instantaneous values } \\
\cline { 3 - 5 } month- & No. & Chloride & Discharge & $\mathrm{Cl} \mathrm{flux}$ \\
year & & $\mathrm{mg} / \mathrm{L}$ & $\mathrm{m}^{3} / \mathrm{s}$ & $\mathrm{g} / \mathrm{s}$
\end{tabular}

\section{Gibbon River}

$\begin{array}{llllll}\text { 31-Dec-84 } & 1096 & & 61.7 & 2.44 & 150 \\ \text { 2-Jan-85 } & 1098 & 1315 & 61.2 & 2.44 & 149 \\ \text { 23-Jan-85 } & 1119 & 1505 & 64.0 & 2.32 & 149 \\ \text { 23-Jan-85 } & 1119 & 1520 & 64.7 & 2.32 & 150 \\ \text { 31-Jan-85 } & 1127 & & 63.6 & 2.24 & 143 \\ & & & & & \\ \text { 21-Feb-85 } & 1148 & 0815 & 60.7 & 2.04 & 124 \\ \text { 21-Feb-85 } & 1148 & 1850 & 55.2 & 2.04 & 113 \\ \text { 28-Feb-85 } & 1155 & & 55.3 & 2.04 & 113 \\ \text { 14-Mar-85 } & 1169 & 0800 & 55.4 & 2.04 & 113 \\ \text { 31-Mar-85 } & 1186 & & 45.1 & 3.50 & 158 \\ & & & & & \\ \text { 17-Apr-85 } & 1203 & 1200 & 34.7 & 4.96 & 172 \\ \text { 30-Appr-85 } & 1216 & & 34.2 & 4.77 & 163 \\ \text { 31-May-85 } & 1247 & & 32.9 & 4.34 & 143 \\ \text { 11-Jun-85 } & 1258 & 1915 & 32.4 & 4.19 & 136 \\ \text { 30-Jun-85 } & 1277 & & 39.9 & 3.87 & 154 \\ & & & & & \\ \text { 23-Jul-85 } & 1300 & 1840 & 48.9 & 3.48 & 170 \\ \text { 31-Jul-85 } & 1308 & & 49.7 & 3.29 & 163 \\ \text { 31-Aug-85 } & 1339 & & 52.7 & 2.53 & 133 \\ \text { 4-Sep-85 } & 1343 & 0900 & 53.1 & 2.44 & 129 \\ \text { 30-Sep-85 } & 1369 & & 55.1 & 2.49 & 137\end{array}$

Water year 1986:

\begin{tabular}{|c|c|c|c|c|}
\hline $\begin{array}{l}16-\text { Oct-85 } \\
31-\text { Oct-85 } \\
8-\text { Nov-85 } \\
\text { 30-Nov-85 } \\
5-\text { Dec-85 }\end{array}$ & $\begin{array}{l}1385 \\
1400 \\
1408 \\
1430 \\
1435\end{array}$ & 1300 & $\begin{array}{l}56.4 \\
76.7 \\
87.5 \\
61.2 \\
55.2\end{array}$ & $\begin{array}{l}2.52 \\
2.56 \\
2.58 \\
2.35 \\
2.29\end{array}$ \\
\hline $\begin{array}{l}\text { 31-Dec-85 } \\
\text { 3-Jan-86 } \\
\text { 31-Jan-86 } \\
\text { 3-Feb-86 } \\
\text { 5-Feb-86 }\end{array}$ & $\begin{array}{l}1461 \\
1464 \\
1492 \\
1495 \\
1497\end{array}$ & $\begin{array}{l}1420 \\
1420 \\
1000\end{array}$ & $\begin{array}{l}52.5 \\
52.2 \\
67.4 \\
69.0 \\
63.0\end{array}$ & $\begin{array}{l}2.07 \\
2.04 \\
2.22 \\
2.24 \\
2.21\end{array}$ \\
\hline $\begin{array}{l}\text { 28-Feb-86 } \\
\text { 2-Mar-86 } \\
\text { 16-Mar-86 } \\
\text { 18-Mar-86 } \\
\text { 31-Mar-86 }\end{array}$ & $\begin{array}{l}1520 \\
1522 \\
1536 \\
1538 \\
1551\end{array}$ & $\begin{array}{l}0935 \\
1448 \\
1800\end{array}$ & $\begin{array}{l}59.2 \\
58.9 \\
64.5 \\
64.5 \\
49.0\end{array}$ & $\begin{array}{l}2.50 \\
2.52 \\
2.24 \\
2.24 \\
3.32\end{array}$ \\
\hline $\begin{array}{l}\text { 8-Apr-86 } \\
\text { 17-Apr-86 } \\
\text { 18-Apr-86 } \\
\text { 30-Apr-86 } \\
\text { 1-May-86 }\end{array}$ & $\begin{array}{l}1559 \\
1568 \\
1569 \\
1581 \\
1582\end{array}$ & $\begin{array}{l}0933 \\
1345 \\
1655 \\
\\
1637\end{array}$ & $\begin{array}{l}39.5 \\
52.1 \\
48.5 \\
40.7 \\
40.1\end{array}$ & $\begin{array}{l}3.99 \\
3.62 \\
3.37 \\
5.85 \\
6.06\end{array}$ \\
\hline $\begin{array}{l}\text { 11-May-86 } \\
\text { 31-May-86 } \\
\text { 8-Jun-86 } \\
\text { 26-Jun-86 } \\
\text { 30-Jun-86 }\end{array}$ & $\begin{array}{l}1592 \\
1612 \\
1620 \\
1638 \\
1642\end{array}$ & $\begin{array}{l}0710 \\
1615\end{array}$ & $\begin{array}{l}33.4 \\
21.2 \\
16.3 \\
24.9 \\
26.2\end{array}$ & $\begin{array}{r}5.10 \\
9.69 \\
11.53 \\
5.61 \\
5.71\end{array}$ \\
\hline $\begin{array}{l}\text { 10-Jul-86 } \\
\text { 23-Jul-86 } \\
\text { 24-Jul-86 } \\
\text { 31-Jul-86 } \\
\text { 6-Aug-86 }\end{array}$ & $\begin{array}{l}1652 \\
1665 \\
1666 \\
1673 \\
1679\end{array}$ & $\begin{array}{l}0825 \\
0730 \\
1717 \\
\\
0820\end{array}$ & $\begin{array}{l}29.5 \\
32.1 \\
31.6 \\
33.8 \\
35.7\end{array}$ & $\begin{array}{l}5.97 \\
3.88 \\
4.08 \\
3.70 \\
3.37\end{array}$ \\
\hline $\begin{array}{l}\text { 20-Aug-86 } \\
\text { 31-Aug-86 } \\
\text { 3-Sep-86 } \\
\text { 4-Sep-86 } \\
\text { 17-Sep-86 }\end{array}$ & $\begin{array}{l}1693 \\
1704 \\
1707 \\
1708 \\
1721\end{array}$ & $\begin{array}{l}1239 \\
0710 \\
0845\end{array}$ & $\begin{array}{l}45.9 \\
44.5 \\
44.1 \\
41.7 \\
45.5\end{array}$ & $\begin{array}{l}3.14 \\
3.01 \\
2.97 \\
2.80 \\
2.72\end{array}$ \\
\hline
\end{tabular}




\begin{tabular}{|c|c|c|c|c|}
\hline \multirow{2}{*}{$\begin{array}{l}\text { Day- } \\
\text { month- } \\
\text { year }\end{array}$} & \multirow{2}{*}{$\begin{array}{l}\text { Date } 1 \text { Time } 2 \\
\text { No. }\end{array}$} & \multicolumn{3}{|c|}{ Instantaneous values } \\
\hline & & $\begin{array}{l}\text { Chloride } \\
\mathrm{mg} / \mathrm{L}\end{array}$ & $\begin{array}{c}\text { Discharge } \\
\mathrm{m}^{3 / \mathrm{s}}\end{array}$ & $\begin{array}{c}\mathrm{Cl} \text { flux } \\
\mathrm{g} / \mathrm{s}\end{array}$ \\
\hline
\end{tabular}

Water year 1987:

$\begin{array}{llllll}\text { 1-Oct-86 } & 1735 & 0743 & 47.4 & 2.80 & 133 \\ \text { 8-Oct-86 } & 1742 & 0900 & 41.3 & 2.58 & 106 \\ \text { 15-Oct-86 } & 1749 & 1153 & 36.0 & 2.46 & 88.7 \\ \text { 25-Oct-86 } & 1759 & 1729 & 36.7 & 2.58 & 94.4 \\ \text { 31-Oct-86 } & 1765 & & 41.3 & 2.63 & 109 \\ & & & & & \\ \text { 9-Nov-86 } & 1774 & 1442 & 48.2 & 2.72 & 131 \\ \text { 18-Nov-86 } & 1783 & 0900 & 50.9 & 2.72 & 138 \\ \text { 27-Nov-86 } & 1792 & 1125 & 50.5 & 2.66 & 134 \\ \text { 30-Nov-86 } & 1795 & & 49.6 & 2.58 & 128 \\ \text { 10-Dec-86 } & 1805 & 1215 & 46.5 & 2.32 & 108 \\ & & & & & \\ \text { 24-Dec-86 } & 1819 & 1133 & 30.0 & 2.38 & 71.4 \\ \text { 31-Dec-86 } & 1826 & & 43.6 & 2.70 & 118 \\ \text { 7-Jan-87 } & 1833 & 1345 & 57.1 & 3.03 & 173 \\ \text { 21-Jan-87 } & 1847 & 1215 & 61.8 & 2.32 & 143 \\ \text { 31-Jan-87 } & 1857 & & 62.4 & 2.26 & 141 \\ & & & & & \\ \text { 4-Feb-87 } & 1861 & 1527 & 62.6 & 2.24 & 140 \\ \text { 18-Feb-87 } & 1875 & 0900 & 63.4 & 2.12 & 135 \\ \text { 18-Feb-87 } & 1875 & 0915 & 63.6 & 2.12 & 135 \\ \text { 28-Feb-87 } & 1885 & & 63.9 & 2.22 & 142 \\ \text { 11-Mar-87 } & 1896 & 0750 & 64.2 & 2.32 & 149 \\ \text { 25-Mar-87 } & 1910 & 1615 & 68.4 & 1.95 & 134 \\ \text { 31-Mar-87 } & 1916 & & 68.1 & 1.95 & 133 \\ \text { 2-Apr-87 } & 1918 & 1545 & 68.0 & 1.95 & 133 \\ \text { 8-Apr-87 } & 1924 & 1325 & 58.1 & 2.46 & 143 \\ \text { 23-Apr-87 } & 1939 & 1650 & 36.7 & 3.74 & 137 \\ & & & & & \\ \text { 30-Apr-87 } & 1946 & & 36.6 & 3.48 & 127 \\ \text { 6-May-87 } & 1952 & 0840 & 36.5 & 3.26 & 119 \\ \text { 19-May-87 } & 1965 & 0800 & 42.9 & 4.50 & 193 \\ \text { 20-May-87 } & 1966 & 0907 & 42.4 & 3.79 & 161 \\ \text { 31-May-87 } & 1977 & & 44.5 & 3.32 & 148 \\ \text { 4-Jun-87 } & 1981 & 1515 & 45.2 & 3.14 & 142 \\ \text { 17-Jun-87 } & 1994 & 1727 & 50.9 & 2.61 & 133 \\ \text { 30-Jun-87 } & 2007 & & 59.4 & 2.45 & 145 \\ \text { 1-Jul-87 } & 2008 & 1715 & 60.0 & 2.44 & 146 \\ \text { 15-Jul-87 } & 2022 & 1521 & 45.3 & 2.32 & 105 \\ & & & & & \\ \text { 26-Jul-87 } & 2033 & 1530 & 40.1 & 2.29 & 92 \\ \text { 31-Jul-87 } & 2038 & & 43.4 & 2.24 & 97 \\ \text { 12-Aug-87 } & 2050 & 1700 & 51.4 & 2.10 & 108 \\ \text { 18-Aug-87 } & 2056 & 0900 & 46.1 & 2.12 & 97 \\ \text { 26-Aug-87 } & 2064 & 1708 & 55.5 & 2.24 & 124 \\ \text { 31-Aug-87 } & 2069 & & 57.3 & 2.14 & 122 \\ \text { 9-Sep-87 } & 2078 & 1450 & 60.6 & 1.95 & 118 \\ \text { 23-Sep-87 } & 2092 & 1655 & 59.5 & 1.84 & 110 \\ \text { 30-Sep-87 } & 2099 & & 59.0 & 1.86 & 109\end{array}$

Water year 1988:

$\begin{array}{llllll}\text { 7-Oct-87 } & 2106 & 1711 & 61.0 & 2.07 & 126 \\ \text { 21-Oct-87 } & 2120 & 1600 & 66.9 & 1.98 & 133 \\ \text { 31-Oct-87 } & 2130 & & 67.0 & 2.02 & 136 \\ \text { 4-Nov-87 } & 2134 & 1010 & 67.1 & 2.04 & 137 \\ \text { 17-Nov-87 } & 2147 & 0845 & 76.2 & 2.07 & 158 \\ & & & & & \\ \text { 30-Nov-87 } & 2160 & & 71.8 & 1.83 & 131 \\ \text { 1-Dec-87 } & 2161 & 0850 & 71.5 & 1.81 & 130 \\ \text { 30-Dec-87 } & 2190 & 1510 & 82.3 & 1.81 & 149\end{array}$

Day Date 1 Time 2 Instantaneous values month- No. Chloride Discharge $\mathrm{Cl}$ flux year $\mathrm{mg} / \mathrm{L} \quad \mathrm{m}^{3} / \mathrm{s}$

$\mathbf{g} / \mathbf{s}$

\section{Gibbon River}

$\begin{array}{llllll}\text { 31-Dec-87 } & 2191 & & 81.7 & 1.86 & 152 \\ \text { 5-Jan-88 } & 2196 & 1025 & 78.8 & 2.12 & 167 \\ \text { 28-Jan-88 } & 2219 & 1237 & 80.2 & 1.76 & 141 \\ \text { 31-Jan-88 } & 2222 & & 79.2 & 1.74 & 138 \\ \text { 17-Feb-88 } & 2239 & 1100 & 74.0 & 1.67 & 124 \\ & & & & & \\ \text { 24-Feb-88 } & 2246 & 1303 & 71.7 & 1.70 & 122 \\ \text { 29-Feb-88 } & 2251 & & 73.0 & 1.70 & 124 \\ \text { 16-Mar-88 } & 2267 & 0836 & 77.3 & 1.70 & 131 \\ \text { 29-Mar-88 } & 2280 & 0910 & 59.8 & 1.67 & 100 \\ \text { 31-Mar-88 } & 2282 & 1130 & 62.0 & 1.61 & 100 \\ \text { 13-Apr-88 } & 2295 & 1658 & 43.6 & 2.78 & 121 \\ \text { 17-Apr-88 } & 2299 & 1645 & 52.4 & 3.54 & 186 \\ \text { 21-Apr-88 } & 2303 & 1716 & 40.3 & 3.94 & 159 \\ \text { 30-Apr-88 } & 2312 & & 44.4 & 3.23 & 143 \\ & & & & & \\ \text { 4-May-88 } & 2316 & 1645 & 46.2 & 2.92 & 135 \\ \text { 12-May-88 } & 2324 & 1614 & 26.9 & 5.18 & 139 \\ \text { 17-May-88 } & 2329 & 0815 & 18.9 & 8.69 & 164 \\ \text { 18-May-88 } & 2330 & 1648 & 20.1 & 7.56 & 152 \\ \text { 25-May-88 } & 2337 & 1650 & 23.2 & 5.44 & 126 \\ \text { 31-May-88 } & 2343 & & 27.9 & 5.02 & 140 \\ \text { 1-Jun-88 } & 2344 & 1600 & 28.7 & 4.96 & 142 \\ \text { 8-Jun-88 } & 2351 & 1827 & 38.5 & 3.14 & 121 \\ \text { 15-Jun-88 } & 2358 & 1654 & 42.8 & 2.80 & 120 \\ \text { 22-Jun-88 } & 2365 & 0845 & 46.9 & 2.58 & 121 \\ & & & & & \\ \text { 29-Jun-88 } & 2372 & 0656 & 49.1 & 2.46 & 121 \\ \text { 30-Jun-88 } & 2373 & & 48.7 & 2.42 & 118 \\ \text { 6-Jul-88 } & 2379 & 0017 & 46.4 & 2.15 & 100 \\ \text { 20-Jul-88 } & 2393 & 0725 & 49.3 & 1.95 & 96.3 \\ \text { 27-Ju1-88 } & 2400 & 0723 & 50.7 & 1.93 & 97.6 \\ & & & & & \\ \text { 31-Ju1-88 } & 2404 & & 50.8 & 1.93 & 97.7 \\ \text { 3-Aug-88 } & 2407 & 0707 & 50.8 & 1.93 & 97.8 \\ \text { 9-Aug-88 } & 2413 & 0911 & 53.5 & 1.87 & 100 \\ \text { 9-Aug-88 } & 2413 & 1743 & 59.8 & 1.93 & 115 \\ \text { 17-Aug-88 } & 2421 & 0941 & 56.9 & 1.84 & 105 \\ & & & & & \\ \text { 24-Aug-88 } & 2428 & 0934 & 57.5 & 1.76 & 101 \\ \text { 31-Aug-88 } & 2435 & 1643 & 61.9 & 1.87 & 116 \\ \text { 7-Sep-88 } & 2442 & 1810 & 68.5 & 1.87 & 128 \\ \text { 20-Sep-88 } & 2455 & 0915 & 67.6 & 1.87 & 126 \\ \text { 21-Sep-88 } & 2456 & 1654 & 67.1 & 1.93 & 129 \\ \text { 30-Sep-88 } & 2465 & & 65.1 & 1.93 & 125\end{array}$

Water year 1989:

$\begin{array}{llllll}\text { 6-Oct-88 } & 2471 & 0930 & 63.7 & 1.8 & 117 \\ \text { 19-Oct-88 } & 2484 & 1738 & 74.7 & 2.0 & 148 \\ \text { 31-Oct-88 } & 2496 & & 74.1 & 2.1 & 157 \\ \text { 3-Nov-88 } & 2499 & 0850 & 73.9 & 2.2 & 159 \\ \text { 16-Nov-88 } & 2512 & 0835 & 73.5 & 2.2 & 158 \\ & & & & & \\ \text { 30-Nov-88 } & 2526 & & 67.6 & 2.1 & 142 \\ \text { 13-Dec-88 } & 2539 & 0945 & 62.2 & 2.0 & 127 \\ \text { 15-Dec-88 } & 2541 & 1448 & 57.1 & 1.8 & 100 \\ \text { 31-Dec-88 } & 2557 & & 66.5 & 2.0 & 133 \\ \text { 10-Jan-89 } & 2567 & 1200 & 72.3 & 2.2 & 156 \\ & & & & & \\ \text { 31-Jan-89 } & 2588 & & 74.8 & 1.9 & 142 \\ \text { 7-Feb-89 } & 2595 & 1530 & 75.6 & 1.8 & 137 \\ \text { 9-Feb-89 } & 2597 & 1100 & 78.8 & 1.9 & 150 \\ \text { 28-Feb-89 } & 2616 & & 79.3 & 2.1 & 169 \\ \text { 7-Mar-89 } & 2623 & 1330 & 79.5 & 22 & 176\end{array}$




\begin{tabular}{|c|c|c|c|c|}
\hline \multirow{2}{*}{$\begin{array}{l}\text { Day- } \\
\text { month- } \\
\text { year }\end{array}$} & \multirow{2}{*}{$\begin{array}{l}\text { Date } 1 \text { Time } 2 \\
\text { No. }\end{array}$} & \multicolumn{3}{|c|}{ Instantaneous values } \\
\hline & & $\begin{array}{c}\text { Chloride } \\
\mathrm{mg} / \mathrm{L}\end{array}$ & $\begin{array}{c}\text { Discharge } \\
\mathrm{m}^{3 / \mathrm{s}}\end{array}$ & $\begin{array}{c}\mathrm{Cl} \text { flux } \\
\mathrm{g} / \mathrm{s}\end{array}$ \\
\hline
\end{tabular}

Gibbon River

\begin{tabular}{llllll} 
8-Mar-89 & 2624 & 1400 & 81.2 & 2.1 & 172 \\
23-Mar-89 & 2639 & 0925 & 72.7 & 2.2 & 161 \\
31-Mar-89 & 2647 & & 73.2 & 2.1 & 153 \\
4-Apr-89 & 2651 & 1151 & 73.5 & 2.0 & 150 \\
19-Apr-89 & 2666 & 1815 & 28.9 & 6.2 & 180 \\
& & & & & \\
30-Apr-89 & 2677 & & 32.5 & 6.2 & 203 \\
3-May-89 & 2680 & 1828 & 33.5 & 6.2 & 209 \\
3-May-89 & 2680 & 1430 & 33.4 & 6.1 & 205 \\
31-May-89 & 2708 & & 30.7 & 5.1 & 157 \\
13-Jun-89 & 2721 & 1615 & 29.5 & 4.6 & 137 \\
& & & & & \\
30-Jun-89 & 2738 & & 37.4 & 3.4 & 129 \\
5-Jul-89 & 2743 & 1945 & 39.7 & 3.1 & 123 \\
13-Jul-89 & 2751 & 1210 & 50.2 & 3.5 & 175 \\
21-Jul-89 & 2759 & 0940 & 42.4 & 2.8 & 119 \\
26-Jul-89 & 2764 & 1400 & 42.4 & 3.1 & 131 \\
& & & & & \\
27-Jul-89 & 2765 & 1800 & 46.6 & 3.1 & 146 \\
31-Jul-89 & 2769 & & 46.1 & 3.0 & 136 \\
4-Aug-89 & 2773 & 1540 & 45.6 & 2.8 & 127 \\
12-Aug-89 & 2781 & 1445 & 46.3 & 2.8 & 128 \\
16-Aug-89 & 2785 & 1200 & 53.1 & 2.7 & 144 \\
& & & & & \\
21-Aug-89 & 2790 & 1030 & 52.7 & 2.7 & 140 \\
27-Aug-89 & 2796 & 0900 & 52.2 & 2.6 & 136 \\
31-Aug-89 & 2800 & & 50.0 & 2.5 & 127 \\
12-Sep-89 & 2812 & 1245 & 43.4 & 2.3 & 101 \\
12-Sep-89 & 2812 & 1426 & 44.5 & 2.3 & 103 \\
26-Sep-89 & 2826 & 1251 & 45.0 & 2.3 & 103 \\
30-Sep-89 & 2830 & & 47.4 & 2.4 & 112 \\
& & & & & \\
\hline
\end{tabular}

\section{Madison River}

Water year 1983:

$\begin{array}{llllll}\text { 30-Sep-82 } & 273 & & 54.7 & 15.1 & 829 \\ \text { 27-Oct-82 } & 300 & 1035 & 56.0 & 16.1 & 902 \\ \text { 31-Oct-82 } & 304 & 1330 & 56.3 & 15.6 & 881 \\ \text { 26-Nov-82 } & 330 & 1035 & 58.5 & 12.6 & 737 \\ \text { 30-Nov-82 } & 334 & & 58.9 & 12.6 & 742 \\ & & & & & \\ \text { 31-Dec-82 } & 365 & & 61.7 & 12.6 & 777 \\ \text { 26-Jan-83 } & 391 & 1000 & 64.0 & 12.6 & 806 \\ \text { 31-Jan-83 } & 396 & & 64.1 & 12.7 & 814 \\ \text { 19-Feb-83 } & 415 & 1230 & 64.6 & 13.1 & 843 \\ \text { 28-Feb-83 } & 424 & & 64.3 & 13.1 & 839 \\ & & & & & \\ \text { 17-Mar-83 } & 441 & 0945 & 63.7 & 13.1 & 831 \\ \text { 31-Mar-83 } & 455 & 1000 & 63.3 & 12.6 & 797 \\ \text { 13-Apr-83 } & 468 & 0730 & 66.2 & 11.7 & 776 \\ \text { 30-Apr-83 } & 485 & & 57.9 & 15.2 & 879 \\ \text { 1-May-83 } & 486 & 0930 & 57.4 & 15.4 & 883 \\ & & & & & \\ \text { 8-May-83 } & 493 & 1000 & 51.3 & 16.9 & 865 \\ \text { 15-May-83 } & 500 & 1000 & 60.9 & 14.9 & 907 \\ \text { 22-May-83 } & 507 & 1000 & 47.0 & 19.2 & 902 \\ \text { 29-May-83 } & 514 & 1000 & 21.0 & 41.3 & 868 \\ \text { 31-May-83 } & 516 & & 23.2 & 38.7 & 899 \\ \text { 5-Jun-83 } & 521 & 1000 & 28.9 & 32.0 & 923 \\ \text { 12-Jun-83 } & 528 & 1000 & 26.1 & 34.8 & 910 \\ \text { 26-Jun-83 } & 542 & 1000 & 37.8 & 19.5 & 737 \\ \text { 30-Jun-83 } & 546 & & 36.1 & 22.1 & 795 \\ \text { 3-Jul-83 } & 549 & 1000 & 34.8 & 24.0 & 834 \\ & & & & & \end{array}$

\begin{tabular}{lcccc}
\hline Day & Date 1 & Time 2 & \multicolumn{3}{c}{ Instantaneous values } \\
\cline { 2 - 5 } month- & No. & Chloride & Discharge & $\mathrm{Cl} \mathrm{flux}$ \\
year & & $\mathrm{mg} / \mathrm{L}$ & $\mathrm{m}^{3 / \mathrm{s}}$ & $\mathrm{g} / \mathrm{s}$ \\
\hline
\end{tabular}

Madison River

$\begin{array}{llllll}\text { 17-Jul-83 } & 563 & 1000 & 45.8 & 16.9 & 773 \\ \text { 24-Jul-83 } & 570 & 1000 & 47.8 & 16.4 & 783 \\ \text { 31-Jul-83 } & 577 & 1000 & 50.4 & 13.1 & 658 \\ \text { 7-Aug-83 } & 584 & 1000 & 50.8 & 12.8 & 652 \\ \text { 14-Aug-83 } & 591 & 1000 & 52.2 & 12.3 & 641 \\ & & & & & \\ \text { 31-Aug-83 } & 608 & & 53.1 & 12.1 & 642 \\ \text { 11-Sep-83 } & 619 & 1000 & 53.8 & 11.9 & 642 \\ \text { 25-Sep-83 } & 633 & 1000 & 52.0 & 11.9 & 621 \\ \text { 30-Sep-83 } & 638 & & 51.6 & 12.3 & 637\end{array}$

\section{Water year 1984:}

\begin{tabular}{|c|c|c|c|c|c|}
\hline $\begin{array}{l}9-\text { Oct-83 } \\
12-\text { Oct-83 } \\
23-\text { Oct-83 } \\
25-\text { Oct-83 } \\
31-\text { Oct }-83\end{array}$ & $\begin{array}{l}647 \\
650 \\
661 \\
663 \\
669\end{array}$ & $\begin{array}{l}1000 \\
1015 \\
1000 \\
1450\end{array}$ & $\begin{array}{l}51.0 \\
53.9 \\
56.2 \\
52.6 \\
54.4\end{array}$ & $\begin{array}{l}13.1 \\
14.4 \\
13.1 \\
13.1 \\
14.1\end{array}$ & $\begin{array}{l}666 \\
776 \\
734 \\
686 \\
767\end{array}$ \\
\hline $\begin{array}{l}\text { 6-Nov-83 } \\
\text { 30-Nov-83 } \\
\text { 4-Dec-83 } \\
\text { 14-Dec-83 } \\
\text { 31-Dec-83 }\end{array}$ & $\begin{array}{l}675 \\
699 \\
703 \\
713 \\
730\end{array}$ & $\begin{array}{l}1000 \\
1000 \\
1000 \\
1000\end{array}$ & $\begin{array}{l}56.2 \\
57.5 \\
57.7 \\
59.5 \\
58.5\end{array}$ & $\begin{array}{l}15.1 \\
13.7 \\
13.5 \\
12.8 \\
12.8\end{array}$ & $\begin{array}{l}852 \\
790 \\
779 \\
763 \\
750\end{array}$ \\
\hline $\begin{array}{l}\text { 25-Jan-84 } \\
\text { 29-Jan-84 } \\
\text { 31-Jan-84 } \\
\text { 29-Feb-84 } \\
\text { 6-Mar-84 }\end{array}$ & $\begin{array}{l}755 \\
759 \\
761 \\
790 \\
796\end{array}$ & $\begin{array}{l}1000 \\
1000\end{array}$ & $\begin{array}{l}60.3 \\
61.5 \\
61.6 \\
63.3 \\
63.7\end{array}$ & $\begin{array}{l}12.1 \\
12.1 \\
12.1 \\
11.6 \\
11.5\end{array}$ & $\begin{array}{l}733 \\
747 \\
746 \\
735 \\
732\end{array}$ \\
\hline $\begin{array}{l}\text { 11-Mar-84 } \\
\text { 25-Mar-84 } \\
\text { 31-Mar-84 } \\
\text { 8-Apr-84 } \\
\text { 17-Apr-84 }\end{array}$ & $\begin{array}{l}801 \\
815 \\
821 \\
829 \\
838\end{array}$ & $\begin{array}{l}1500 \\
1000 \\
1000 \\
1120\end{array}$ & $\begin{array}{l}65.0 \\
64.7 \\
64.5 \\
64.3 \\
53.2\end{array}$ & $\begin{array}{l}11.7 \\
11.7 \\
11.7 \\
11.7 \\
13.6\end{array}$ & $\begin{array}{l}760 \\
758 \\
756 \\
752 \\
723\end{array}$ \\
\hline $\begin{array}{l}\text { 22-Apr-84 } \\
\text { 30-Apr-84 } \\
\text { 7-May-84 } \\
\text { 13-May-84 } \\
\text { 21-May-84 }\end{array}$ & $\begin{array}{l}843 \\
851 \\
858 \\
864 \\
872\end{array}$ & $\begin{array}{l}1900 \\
1000 \\
1000 \\
1000 \\
1000\end{array}$ & $\begin{array}{l}52.7 \\
61.4 \\
61.1 \\
35.3 \\
20.7\end{array}$ & $\begin{array}{l}13.3 \\
12.4 \\
12.4 \\
23.5 \\
45.6\end{array}$ & $\begin{array}{l}700 \\
760 \\
756 \\
829 \\
944\end{array}$ \\
\hline $\begin{array}{l}\text { 30-May-84 } \\
\text { 31-May-84 } \\
\text { 6-Jun-84 } \\
\text { 10-Jun-84 } \\
\text { 22-Jun-84 }\end{array}$ & $\begin{array}{l}881 \\
882 \\
888 \\
892 \\
904\end{array}$ & $\begin{array}{l}1615 \\
0820 \\
0630 \\
1000\end{array}$ & $\begin{array}{l}22.1 \\
23.2 \\
29.9 \\
34.4 \\
33.3\end{array}$ & $\begin{array}{l}34.8 \\
33.5 \\
25.7 \\
25.5 \\
22.8\end{array}$ & $\begin{array}{l}770 \\
778 \\
768 \\
876 \\
759\end{array}$ \\
\hline $\begin{array}{l}\text { 30-Jun-84 } \\
6 \text {-Jul-84 } \\
\text { 11-Jul-84 } \\
\text { 14-Jul-84 } \\
\text { 20-Jul-84 }\end{array}$ & $\begin{array}{l}912 \\
918 \\
923 \\
926 \\
932\end{array}$ & $\begin{array}{l}1000 \\
1215 \\
1000 \\
1000\end{array}$ & $\begin{array}{l}38.7 \\
42.7 \\
46.1 \\
44.5 \\
45.1\end{array}$ & $\begin{array}{l}18.3 \\
14.9 \\
14.5 \\
13.7 \\
13.7\end{array}$ & $\begin{array}{l}707 \\
636 \\
668 \\
611 \\
619\end{array}$ \\
\hline $\begin{array}{l}27-J u l-84 \\
31-J u l-84 \\
10-A u g-84 \\
17-A u g-84 \\
21-A u g-84\end{array}$ & $\begin{array}{l}939 \\
943 \\
953 \\
960 \\
964\end{array}$ & $\begin{array}{l}1500 \\
1000 \\
1000 \\
1410\end{array}$ & $\begin{array}{l}47.5 \\
48.1 \\
49.7 \\
49.2 \\
48.6\end{array}$ & $\begin{array}{l}14.9 \\
14.6 \\
13.7 \\
15.1 \\
13.8\end{array}$ & $\begin{array}{l}708 \\
701 \\
683 \\
745 \\
672\end{array}$ \\
\hline $\begin{array}{l}\text { 24-Aug-84 } \\
\text { 31-Aug-84 } \\
\text { 6-Sep-84 } \\
\text { 14-Sep-84 } \\
\text { 30-Sep-84 }\end{array}$ & $\begin{array}{l}967 \\
974 \\
980 \\
988 \\
1004\end{array}$ & $\begin{array}{l}1000 \\
1000 \\
1000 \\
1000\end{array}$ & $\begin{array}{l}52.3 \\
52.4 \\
53.1 \\
52.9 \\
55.4\end{array}$ & $\begin{array}{l}14.4 \\
13.5 \\
13.7 \\
12.8 \\
13.2\end{array}$ & $\begin{array}{l}754 \\
708 \\
729 \\
679 \\
732\end{array}$ \\
\hline
\end{tabular}




\begin{tabular}{|c|c|c|c|c|}
\hline \multirow{2}{*}{$\begin{array}{l}\text { Day- } \\
\text { month- } \\
\text { year }\end{array}$} & \multirow{2}{*}{$\begin{array}{l}\text { Date } 1 \text { Time } 2 \\
\text { No. }\end{array}$} & \multicolumn{3}{|c|}{ Instantaneous values } \\
\hline & & $\begin{array}{l}\text { Chloride } \\
\mathrm{mg} / \mathrm{L}\end{array}$ & $\begin{array}{c}\text { Discharge } \\
\mathrm{m}^{3 / \mathrm{s}}\end{array}$ & $\begin{array}{c}\text { Cl flux } \\
\text { g/s }\end{array}$ \\
\hline \multicolumn{5}{|c|}{ Madison River } \\
\hline
\end{tabular}

\begin{tabular}{|c|c|c|c|c|c|}
\hline \multirow{2}{*}{$\begin{array}{l}\text { Day } \\
\text { month- } \\
\text { year }\end{array}$} & \multirow{2}{*}{$\begin{array}{c}\text { Date } 1 \\
\text { No. }\end{array}$} & \multirow{2}{*}{ Time 2} & \multicolumn{3}{|c|}{ Instantaneous values } \\
\hline & & & $\begin{array}{l}\text { Chloride } \\
\mathrm{mg} / \mathrm{L}\end{array}$ & $\begin{array}{c}\text { Discharge } \\
\mathrm{m} 3 / \mathrm{s}\end{array}$ & $\begin{array}{c}\text { Cl flux } \\
\text { g/s }\end{array}$ \\
\hline \multicolumn{6}{|c|}{ Madison River } \\
\hline
\end{tabular}

Water year 1985:

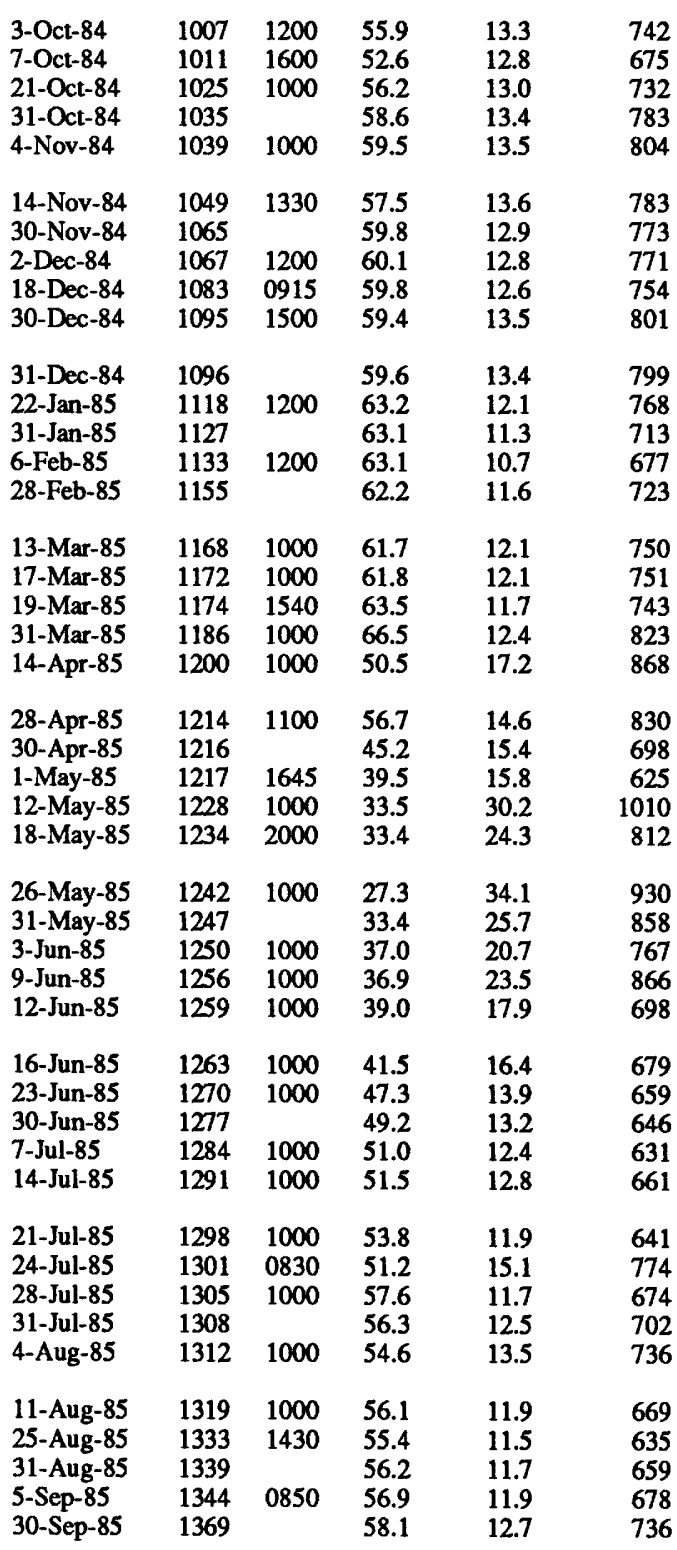

Water year 1986:

$\begin{array}{llllll}\text { 13-Oct-85 } & 1382 & 1000 & 60.0 & 13.3 & 795 \\ \text { 16-Oct-85 } & 1385 & 1735 & 59.0 & 13.0 & 769 \\ \text { 20-Oct-85 } & 1389 & 1100 & 57.8 & 13.0 & 753 \\ \text { 31-Oct-85 } & 1400 & & 58.9 & 12.8 & 754 \\ \text { 21-Nov-85 } & 1421 & 0900 & 61.0 & 12.4 & 755 \\ & & & & & \\ \text { 30-Nov-85 } & 1430 & & 61.3 & 12.8 & 783 \\ \text { 1-Dec-85 } & 1431 & 1330 & 61.3 & 12.8 & 786 \\ \text { 31-Dec-85 } & 1461 & & 60.3 & 12.1 & 730 \\ \text { 7-Jan-86 } & 1468 & 1000 & 60.1 & 11.9 & 716\end{array}$

\begin{tabular}{|c|c|c|c|c|c|}
\hline $\begin{array}{l}\text { 12-Jan-86 } \\
\text { 31-Jan-86 } \\
\text { 3-Feb-86 } \\
\text { 28-Feb-86 } \\
\text { 2-Mar-86 }\end{array}$ & $\begin{array}{l}1473 \\
1492 \\
1495 \\
1520 \\
1522\end{array}$ & $\begin{array}{l}1000 \\
1000\end{array}$ & $\begin{array}{l}60.5 \\
63.8 \\
64.3 \\
63.5 \\
63.4\end{array}$ & $\begin{array}{l}11.7 \\
12.3 \\
12.4 \\
13.2 \\
13.3\end{array}$ & $\begin{array}{l}708 \\
783 \\
796 \\
837 \\
840\end{array}$ \\
\hline $\begin{array}{l}\text { 5-Mar-86 } \\
\text { 16-Mar-86 } \\
\text { 30-Mar-86 } \\
\text { 31-Mar-86 } \\
\text { 17-Apr-86 }\end{array}$ & $\begin{array}{l}1525 \\
1536 \\
1550 \\
1551 \\
1568\end{array}$ & $\begin{array}{l}0900 \\
1000 \\
0900 \\
0815\end{array}$ & $\begin{array}{l}64.8 \\
64.4 \\
49.4 \\
49.7 \\
55.1\end{array}$ & $\begin{array}{l}12.8 \\
12.6 \\
18.2 \\
18.1 \\
16.6\end{array}$ & $\begin{array}{l}831 \\
812 \\
897 \\
898 \\
916\end{array}$ \\
\hline $\begin{array}{l}\text { 27-Apr-86 } \\
\text { 30-Apr-86 } \\
\text { 11-May-86 } \\
\text { 18-May-86 } \\
\text { 25-May-86 }\end{array}$ & $\begin{array}{l}1578 \\
1581 \\
1592 \\
1599 \\
1606\end{array}$ & $\begin{array}{l}1000 \\
1000 \\
1000 \\
1130\end{array}$ & $\begin{array}{l}48.0 \\
47.3 \\
44.9 \\
46.7 \\
20.0\end{array}$ & $\begin{array}{l}17.9 \\
18.6 \\
21.3 \\
19.4 \\
32.1\end{array}$ & $\begin{array}{l}859 \\
881 \\
955 \\
907 \\
642\end{array}$ \\
\hline $\begin{array}{l}\text { 28-May-86 } \\
\text { 31-May-86 } \\
\text { 1-Jun-86 } \\
\text { 8-Jun-86 } \\
\text { 15-Jun-86 }\end{array}$ & $\begin{array}{l}1609 \\
1612 \\
1613 \\
1620 \\
1627\end{array}$ & $\begin{array}{l}1425 \\
1000 \\
1000 \\
1000\end{array}$ & $\begin{array}{l}16.2 \\
15.2 \\
14.8 \\
20.5 \\
27.5\end{array}$ & $\begin{array}{l}51.6 \\
60.4 \\
63.4 \\
40.6 \\
36.8\end{array}$ & $\begin{array}{r}835 \\
916 \\
938 \\
832 \\
1012\end{array}$ \\
\hline $\begin{array}{l}\text { 30-Jun-86 } \\
\text { 6-Jul-86 } \\
\text { 13-Jul-86 } \\
\text { 15-Jul-86 } \\
\text { 20-Jul-86 }\end{array}$ & $\begin{array}{l}1642 \\
1648 \\
1655 \\
1657 \\
1662\end{array}$ & $\begin{array}{l}1300 \\
1345 \\
1530 \\
1300\end{array}$ & $\begin{array}{l}34.8 \\
37.7 \\
38.9 \\
40.3 \\
41.4\end{array}$ & $\begin{array}{l}23.7 \\
18.4 \\
18.7 \\
17.4 \\
17.2\end{array}$ & $\begin{array}{l}823 \\
694 \\
726 \\
702 \\
710\end{array}$ \\
\hline $\begin{array}{l}\text { 27-Jul-86 } \\
\text { 31-Jul-86 } \\
\text { 5-Aug-86 } \\
\text { 10-Aug-86 } \\
\text { 17-Aug-86 }\end{array}$ & $\begin{array}{l}1669 \\
1673 \\
1678 \\
1683 \\
1690\end{array}$ & $\begin{array}{l}1100 \\
1400 \\
1330 \\
1200\end{array}$ & $\begin{array}{l}37.3 \\
40.7 \\
44.9 \\
45.9 \\
45.9\end{array}$ & $\begin{array}{l}21.0 \\
18.6 \\
15.6 \\
16.1 \\
14.9\end{array}$ & $\begin{array}{l}784 \\
757 \\
701 \\
740 \\
682\end{array}$ \\
\hline $\begin{array}{l}\text { 24-Aug-86 } \\
\text { 31-Aug-86 } \\
\text { 3-Sep-86 } \\
\text { 30-Sep-86 }\end{array}$ & $\begin{array}{l}1697 \\
1704 \\
1707 \\
1734\end{array}$ & $\begin{array}{l}1000 \\
1125\end{array}$ & $\begin{array}{l}45.9 \\
45.9 \\
45.9 \\
47.5\end{array}$ & $\begin{array}{l}16.6 \\
16.1 \\
15.9 \\
14.9\end{array}$ & $\begin{array}{l}763 \\
738 \\
728 \\
709\end{array}$ \\
\hline
\end{tabular}

\section{Snake River}

\section{Water Year 1983:}

$\begin{array}{llllll}\text { 30-Sep-82 } & 273 & & 14.2 & 13.4 & 191 \\ \text { 8-Oct-82 } & 281 & 0850 & 12.8 & 14.3 & 183 \\ \text { 31-Oct-82 } & 304 & & 14.0 & 13.9 & 196 \\ \text { 1-Nov-82 } & 305 & 0840 & 14.1 & 13.9 & 196 \\ \text { 30-Nov-82 } & 334 & & 15.2 & 12.9 & 196 \\ & & & & & \\ \text { 10-Dec-82 } & 344 & 1245 & 15.6 & 12.5 & 195 \\ \text { 31-Dec-82 } & 365 & & 16.2 & 13.5 & 219 \\ \text { 26-Jan-83 } & 391 & 1315 & 16.5 & 11.0 & 181 \\ \text { 31-Jan-83 } & 396 & & 16.4 & 11.0 & 181 \\ \text { 18-Feb-83 } & 414 & 1245 & 16.4 & 11.0 & 180 \\ & & & & & \\ \text { 28-Feb-83 } & 424 & & 16.6 & 11.0 & 183 \\ \text { 11-Mar-83 } & 435 & 1545 & 16.9 & 11.0 & 186 \\ \text { 23-Mar-83 } & 447 & 0910 & 17.1 & 10.8 & 184 \\ \text { 31-Mar-83 } & 455 & & 17.0 & 10.6 & 180 \\ \text { 18-Apr-83 } & 473 & 1515 & 16.8 & 10.2 & 171 \\ & & & & & \\ \text { 30-Apr-83 } & 485 & & 14.5 & 12.9 & 188 \\ \text { 13-May-83 } & 498 & 0850 & 12.1 & 15.9 & 193 \\ \text { 16-May-83 } & 501 & 1520 & 13.2 & 16.1 & 213\end{array}$




\begin{tabular}{|c|c|c|c|c|}
\hline \multirow{2}{*}{$\begin{array}{l}\text { Day- } \\
\text { month- } \\
\text { year }\end{array}$} & \multirow{2}{*}{$\begin{array}{l}\text { Date } 1 \text { Time } 2 \\
\text { No. }\end{array}$} & \multicolumn{3}{|c|}{ Instantaneous values } \\
\hline & & $\begin{array}{l}\text { Chloride } \\
\mathrm{mg} / \mathrm{L}\end{array}$ & $\begin{array}{c}\text { Discharge } \\
\mathrm{m}^{3 / \mathrm{s}}\end{array}$ & $\begin{array}{c}\mathrm{Cl} \text { flux } \\
\mathrm{g} / \mathrm{s}\end{array}$ \\
\hline \multicolumn{5}{|c|}{ Snake River } \\
\hline
\end{tabular}

$\begin{array}{lllrrl}\text { 25-May-83 } & 510 & 1230 & 4.4 & 79.9 & 352 \\ \text { 30-May-83 } & 515 & 1010 & 2.9 & 198.2 & 575 \\ \text { 31-May-83 } & 516 & & 2.9 & 193.4 & 567 \\ \text { 7-Jun-83 } & 523 & 1020 & 3.2 & 159.7 & 503 \\ \text { 13-Jun-83 } & 529 & 1120 & 4.3 & 118.1 & 505 \\ & & & & & \\ \text { 20-Jun-83 } & 536 & 1530 & 4.0 & 105.0 & 418 \\ \text { 27-Jun-83 } & 543 & 1305 & 3.6 & 98.5 & 358 \\ \text { 30-Jun-83 } & 546 & & 4.1 & 88.4 & 360 \\ \text { 11-Jul-83 } & 557 & 1140 & 5.7 & 51.5 & 292 \\ \text { 28-Jul-83 } & 574 & 1310 & 10.2 & 21.0 & 214 \\ & & & 10.2 & 20.6 & 210 \\ \text { 31-Jul-83 } & 577 & & 10.2 & 17.8 & 185 \\ \text { 22-Aug-83 } & 599 & 1605 & 10.4 & 18.0 & 226 \\ \text { 31-Aug-83 } & 608 & & 12.5 & 18.0 \\ \text { 2-Sep-83 } & 610 & 0945 & 13.0 & 18.1 & 235 \\ \text { 12-Sep-83 } & 620 & 1030 & 13.3 & 17.0 & 226 \\ \text { 30-Sep-83 } & 638 & & 11.4 & 18.8 & 215\end{array}$

Water year 1984:

$\begin{array}{lllrrr}\text { 7-Oct-83 } & 645 & 1145 & 10.8 & 19.5 & 211 \\ \text { 24-Oct-83 } & 662 & 0515 & 9.8 & 16.7 & 164 \\ \text { 31-Oct-83 } & 669 & & 9.1 & 18.9 & 172 \\ \text { 7-Nov-83 } & 676 & 1223 & 8.4 & 21.0 & 176 \\ \text { 30-Nov-83 } & 699 & & 10.8 & 18.2 & 197 \\ & & & & & \\ \text { 12-Dec-83 } & 711 & 1215 & 12.1 & 16.8 & 203 \\ \text { 31-Dec-83 } & 730 & & 14.4 & 16.1 & 232 \\ \text { 12-Jan-84 } & 742 & 1410 & 15.8 & 15.7 & 249 \\ \text { 31-Jan-84 } & 761 & & 15.8 & 13.7 & 218 \\ \text { 27-Feb-84 } & 788 & 1515 & 15.9 & 10.9 & 173 \\ & & & & & \\ \text { 29-Feb-84 } & 790 & & 15.9 & 10.8 & 173 \\ \text { 15-Mar-84 } & 805 & 1505 & 16.2 & 10.6 & 172 \\ \text { 31-Mar-84 } & 821 & & 17.8 & 10.0 & 179 \\ \text { 2-Apr-84 } & 823 & 1130 & 18.0 & 10.0 & 179 \\ \text { 16-Apr-84 } & 837 & 1145 & 15.1 & 11.4 & 173 \\ & & & & & \\ \text { 27-Apr-84 } & 848 & 0835 & 14.0 & 13.2 & 184 \\ \text { 30-Apr-84 } & 851 & & 14.2 & 13.8 & 196 \\ \text { 3-May-84 } & 854 & 1330 & 14.4 & 14.4 & 208 \\ \text { 11-May-84 } & 862 & 0930 & 11.5 & 18.8 & 216 \\ \text { 14-May-84 } & 865 & 1330 & 4.9 & 60.3 & 294 \\ \text { 15-May-84 } & 866 & 1820 & 3.5 & 108.7 & 382 \\ \text { 20-May-84 } & 871 & 1330 & 4.1 & 100.2 & 406 \\ \text { 24-May-84 } & 875 & 1410 & 3.3 & 88.3 & 292 \\ \text { 31-May-84 } & 882 & & 4.4 & 84.6 & 369 \\ \text { 9-Jun-84 } & 891 & 1210 & 5.7 & 79.9 & 455 \\ \text { 12-Jun-84 } & 894 & 1603 & 5.7 & 71.4 & 407 \\ \text { 30-Jun-84 } & 912 & & 7.2 & 47.4 & 341 \\ \text { 17-Jul-84 } & 929 & 1810 & 8.6 & 24.7 & 213 \\ \text { 26-Jul-84 } & 938 & 1525 & 9.8 & 21.8 & 214 \\ \text { 31-Jul-84 } & 943 & & 10.0 & 20.1 & 200 \\ \text { 14-Aug-84 } & 957 & 1303 & 10.4 & 15.2 & 158 \\ \text { 31-Aug-84 } & 974 & & 11.7 & 14.0 & 164 \\ \text { 30-Sep-84 } & 1004 & & 14.0 & 11.9 & 167 \\ & & & & & \\ \text { Water year } 1985: & & & \\ & & & & & \\ \text { 7-Oct-84 } & 1011 & 1745 & 14.5 & 11.4 & 16 \\ \text { 21-Oct-84 } & 1025 & 1715 & 15.7 & 11.0 & 172 \\ \text { 23-Oct-84 } & 1027 & 1723 & 14.8 & 11.8 & 174 \\ \text { 31-Oct-84 } & 1035 & & 15.0 & 12.6 & 189\end{array}$

\begin{tabular}{|c|c|c|c|c|c|}
\hline \multirow{2}{*}{$\begin{array}{l}\text { Day } \\
\text { month- } \\
\text { year }\end{array}$} & \multirow{2}{*}{$\begin{array}{c}\text { Date } 1 \\
\text { No. }\end{array}$} & \multirow{2}{*}{ Time 2} & \multicolumn{3}{|c|}{ Instantaneous values } \\
\hline & & & $\begin{array}{l}\text { Chloride } \\
\mathrm{mg} / \mathrm{L}\end{array}$ & $\begin{array}{c}\text { Discharge } \\
\mathrm{m}^{3 / \mathrm{s}}\end{array}$ & $\begin{array}{c}\mathrm{Cl} \text { flux } \\
\mathrm{g} / \mathrm{s}\end{array}$ \\
\hline \multicolumn{6}{|c|}{ Snake River } \\
\hline
\end{tabular}

$\begin{array}{llllll}\text { 4-Nov-84 } & 1039 & 1630 & 15.1 & 13.0 & 197 \\ \text { 30-Nov-84 } & 1065 & & 14.9 & 11.2 & 168 \\ \text { 2-Dec-84 } & 1067 & 1320 & 14.9 & 11.1 & 165 \\ \text { 11-Dec-84 } & 1076 & 1500 & 15.5 & 11.8 & 183 \\ \text { 30-Dec-84 } & 1095 & 1600 & 15.2 & 11.7 & 177 \\ & & & & & \\ \text { 31-Dec-84 } & 1096 & & 15.2 & 11.6 & 177 \\ \text { 20-Jan-85 } & 1116 & 1500 & 16.2 & 11.0 & 178 \\ \text { 31-Jan-85 } & 1127 & & 15.8 & 10.9 & 172 \\ \text { 9-Feb-85 } & 1136 & 1345 & 15.5 & 10.8 & 167 \\ \text { 17-Feb-85 } & 1144 & 0730 & 19.2 & 9.4 & 180 \\ \text { 8-Feb-85 } & 1155 & & 18.2 & 9.5 & 172 \\ \text { 3-Mar-85 } & 1158 & 1600 & 17.9 & 9.5 & 170 \\ \text { 18-Mar-85 } & 1173 & 1130 & 19.7 & 9.5 & 186 \\ \text { 31-Mar-85 } & 1186 & 0850 & 21.0 & 9.7 & 205 \\ \text { 15-Apr-85 } & 1201 & 1445 & 11.6 & 16.9 & 196 \\ & & & & & \\ \text { 16-Apr-85 } & 1202 & 1350 & 11.9 & 19.8 & 236 \\ \text { 28-Apr-85 } & 1214 & 1610 & 12.4 & 16.4 & 204 \\ \text { 30-Apr-85 } & 1216 & & 11.4 & 24.1 & 275 \\ \text { 12-May-85 } & 1228 & 1745 & 5.4 & 70.2 & 377 \\ \text { 14-May-85 } & 1230 & 1850 & 5.9 & 64.0 & 379 \\ \text { 29-May-85 } & 1245 & 1730 & 4.2 & 124.9 & 522 \\ \text { 31-May-85 } & 1247 & & 5.0 & 100.1 & 498 \\ \text { 2-Jun-85 } & 1249 & 1800 & 5.8 & 75.3 & 434 \\ \text { 10-Jun-85 } & 1257 & 1800 & 4.4 & 80.4 & 351 \\ \text { 16-Jun-85 } & 1263 & 1740 & 5.2 & 60.3 & 316 \\ & & & & & \\ \text { 18-Jun-85 } & 1265 & 2000 & 5.4 & 52.7 & 282 \\ \text { 23-Jun-85 } & 1270 & 1750 & 6.9 & 36.0 & 247 \\ \text { 30-Jun-85 } & 1277 & 1635 & 8.0 & 27.5 & 219 \\ \text { 10-Jul-85 } & 1287 & 1645 & 9.2 & 18.3 & 169 \\ \text { 14-Jul-85 } & 1291 & 1715 & 10.8 & 16.4 & 177 \\ & & & & & \\ \text { 16-Jul-85 } & 1293 & 1850 & 11.2 & 15.2 & 171 \\ \text { 21-Jul-85 } & 1298 & 1645 & 11.9 & 14.7 & 176 \\ \text { 28-Jul-85 } & 1305 & 1200 & 12.1 & 14.3 & 174 \\ \text { 31-Jul-85 } & 1308 & & 12.2 & 14.3 & 175 \\ \text { 5-Aug-85 } & 1313 & 1645 & 12.4 & 14.2 & 176 \\ \text { 13-Aug-85 } & 1321 & 1700 & 13.5 & 12.1 & 163 \\ \text { 18-Aug-85 } & 1326 & 1645 & 14.4 & 11.2 & 161 \\ \text { 20-Aug-85 } & 1328 & 1639 & 14.5 & 10.5 & 152 \\ \text { 29-Aug-85 } & 1337 & 1745 & 15.7 & 10.1 & 158 \\ & & & & & \\ \text { 9-Sep-85 } & 1348 & 1805 & 13.3 & 10.9 & 145 \\ \text { 25-Sep-85 } & 1364 & 1900 & 15.4 & 11.1 & 171 \\ \text { 30-Sep-85 } & 1369 & & 15.5 & 11.6 & 179\end{array}$

\section{Water year 1986:}

$\begin{array}{llllrl}\text { 1-Oct-85 } & 1370 & 1100 & 15.5 & 9.6 & 149 \\ \text { 13-Oct-85 } & 1382 & 1630 & 16.8 & 10.1 & 170 \\ \text { 22-Oct-85 } & 1391 & 1630 & 15.9 & 10.7 & 170 \\ \text { 31-Oct-85 } & 1400 & & 15.1 & 12.6 & 191 \\ \text { 5-Nov-85 } & 1405 & 1300 & 14.8 & 13.6 & 202 \\ & & & & & \\ \text { 30-Nov-85 } & 1430 & & 16.1 & 11.7 & 191 \\ \text { 2-Dec-85 } & 1432 & 1500 & 16.2 & 11.6 & 188 \\ \text { 17-Dec-85 } & 1447 & 0815 & 16.8 & 10.5 & 177 \\ \text { 31-Dec-85 } & 1461 & & 17.2 & 9.8 & 154 \\ \text { 5-Jan-86 } & 1466 & 1530 & 17.4 & 9.6 & 167 \\ & & & & & \\ \text { 31-Jan-86 } & 1492 & & 17.4 & 10.6 & 184 \\ \text { 3-Feb-86 } & 1495 & 1630 & 17.4 & 10.7 & 186 \\ \text { 19-Feb-86 } & 1511 & 1445 & 14.6 & 14.9 & 217 \\ \text { 28-Feb-86 } & 1520 & & 15.1 & 15.0 & 226\end{array}$




\begin{tabular}{|c|c|c|c|c|}
\hline \multirow{2}{*}{$\begin{array}{l}\text { Day- } \\
\text { month- } \\
\text { year }\end{array}$} & \multirow{2}{*}{$\begin{array}{c}\text { Date } 1 \\
\text { No. }\end{array}$} & \multicolumn{3}{|c|}{ Instantaneous values } \\
\hline & & $\begin{array}{l}\text { Chloride } \\
\mathrm{mg} / \mathrm{L}\end{array}$ & $\begin{array}{c}\text { Discharge } \\
\mathrm{m}^{3 / s}\end{array}$ & $\begin{array}{c}\text { Cl flux } \\
\text { g/s }\end{array}$ \\
\hline \multicolumn{5}{|c|}{ Snake River } \\
\hline
\end{tabular}

\begin{tabular}{lllrrr} 
11-Mar-86 & 1531 & 0830 & 15.7 & 15.1 & 237 \\
22-Mar-86 & 1542 & 1600 & 16.4 & 12.5 & 205 \\
31-Mar-86 & 1551 & & 13.9 & 18.9 & 263 \\
4-Apr-86 & 1555 & 0800 & 12.8 & 21.7 & 278 \\
30-Apr-86 & 1581 & & 9.0 & 26.0 & 234 \\
& & & & & \\
2-May-86 & 1583 & 1500 & 8.6 & 27.2 & 234 \\
13-May-86 & 1594 & 1015 & 9.6 & 26.1 & 251 \\
23-May-86 & 1604 & 1045 & 4.6 & 53.8 & 250 \\
30-May-86 & 1611 & 0900 & 2.9 & 189.7 & 556 \\
31-May-86 & 1612 & & 3.4 & 199.9 & 676 \\
& & & & & \\
6-Jun-86 & 1618 & 0900 & 6.1 & 260.8 & 1591 \\
12-Jun-86 & 1624 & 0900 & 5.5 & 176.6 & 973 \\
18-Jun-86 & 1630 & 1815 & 3.2 & 136.3 & 435 \\
19-Jun-86 & 1631 & 1900 & 3.2 & 132.2 & 428 \\
& & & & & \\
30-Jun-86 & 1642 & & 4.5 & 73.8 & 332 \\
5-Jul-86 & 1647 & 1100 & 6.0 & 49.5 & 297 \\
9-Jul-86 & 1651 & 1810 & 6.7 & 41.1 & 276 \\
15-Jul-86 & 1657 & 1530 & 7.6 & 33.1 & 253 \\
19-Jul-86 & 1661 & 1315 & 7.9 & 31.2 & 247 \\
& & & & & \\
26-Jul-86 & 1668 & 1300 & 7.1 & 36.7 & 260 \\
31-Jul-86 & 1673 & & 8.5 & 27.2 & 231 \\
2-Aug-86 & 1675 & 1430 & 9.1 & 23.4 & 212 \\
9-Aug-86 & 1682 & 0815 & 10.3 & 19.7 & 203 \\
13-Aug-86 & 1686 & 1905 & 10.8 & 18.0 & 194 \\
& & & & & \\
19-Aug-86 & 1692 & 1630 & 11.8 & 15.9 & 187 \\
23-Aug-86 & 1696 & 1215 & 11.2 & 16.8 & 188 \\
27-Aug-86 & 1700 & 1800 & 11.2 & 17.6 & 197 \\
31-Aug-86 & 1704 & & 11.7 & 16.3 & 192 \\
6-Sep-86 & 1710 & 1150 & 12.5 & 14.5 & 182 \\
20-Sep-86 & 1724 & 1100 & 12.4 & 14.7 & 183 \\
30-Sep-86 & 1734 & & 12.9 & 13.8 & 177 \\
\hline & & & & &
\end{tabular}

Water year 1987:

$\begin{array}{llllll}\text { 4-Oct-86 } & 1738 & 1000 & 13.1 & 13.8 & 175 \\ \text { 15-Oct-86 } & 1749 & 1200 & 13.8 & 12.3 & 163 \\ \text { 21-Oct-86 } & 1755 & 1420 & 13.7 & 12.9 & 171 \\ \text { 30-Oct-86 } & 1764 & 1345 & 15.7 & 14.0 & 213 \\ \text { 31-Oct-86 } & 1765 & & 15.7 & 13.4 & 210 \\ & & & & & \\ \text { 10-Nov-86 } & 1775 & 1030 & 15.5 & 12.1 & 181 \\ \text { 30-Nov-86 } & 1795 & & 16.7 & 10.8 & 181 \\ \text { 17-Dec-86 } & 1812 & 0930 & 17.7 & 10.5 & 179 \\ \text { 31-Dec-86 } & 1826 & 0850 & 16.1 & 10.1 & 156 \\ \text { 12-Jan-87 } & 1838 & 1030 & 18.5 & 8.6 & 153 \\ & & & & & \\ \text { 31-Jan-87 } & 1857 & & 17.7 & 9.6 & 170 \\ \text { 10-Feb-87 } & 1867 & 0930 & 17.3 & 10.6 & 177 \\ \text { 13-Feb-87 } & 1870 & 1215 & 17.7 & 10.9 & 187 \\ \text { 28-Feb-87 } & 1885 & & 17.6 & 10.2 & 180 \\ \text { 15-Mar-87 } & 1900 & 1100 & 17.6 & 10.2 & 174 \\ & & & & & \\ \text { 20-Mar-87 } & 1905 & 0915 & 17.6 & 9.7 & 164 \\ \text { 31-Mar-87 } & 1916 & & 16.8 & 9.8 & 165 \\ \text { 10-Apr-87 } & 1926 & 1100 & 16.1 & 10.6 & 165 \\ \text { 21-Apr-87 } & 1937 & 1310 & 10.9 & 19.2 & 202 \\ \text { 30-Apr-87 } & 1946 & & 6.9 & 37.7 & 261 \\ & & & & & \\ \text { 6-May-87 } & 1952 & 1000 & 4.3 & 52.3 & 216 \\ \text { 14-May-87 } & 1960 & 0715 & 4.9 & 56.1 & 264 \\ \text { 23-May-87 } & 1969 & 1100 & 6.8 & 39.6 & 260 \\ \text { 27-May-87 } & 1973 & 1538 & 6.6 & 42.2 & 269\end{array}$

\begin{tabular}{|c|c|c|c|c|c|}
\hline Day & Date 1 & Time 2 & Inst & Intaneous ve & lues \\
\hline $\begin{array}{l}\text { month- } \\
\text { year }\end{array}$ & No. & & $\begin{array}{c}\text { Chloride } \\
\mathrm{mg} / \mathrm{L}\end{array}$ & $\begin{array}{c}\text { Discharge } \\
\mathrm{m} 3 / \mathrm{s}\end{array}$ & $\begin{array}{c}\text { Cl flux } \\
\text { g/s }\end{array}$ \\
\hline
\end{tabular}

\section{Snake River}

$\begin{array}{llllll}\text { 29-May-87 } & 1975 & 1435 & 5.6 & 48.2 & 261 \\ \text { 31-May-87 } & 1977 & & 6.0 & 42.4 & 256 \\ \text { 6-Jun-87 } & 1983 & 1135 & 7.2 & 31.3 & 219 \\ \text { 9-Jun-87 } & 1986 & 1335 & 7.3 & 29.8 & 209 \\ \text { 13-Jun-87 } & 1990 & 1130 & 8.3 & 26.1 & 209 \\ & & & & & \\ \text { 19-Jun-87 } & 1996 & 0830 & 10.2 & 19.0 & 187 \\ \text { 27-Jun-87 } & 2004 & 1130 & 11.8 & 13.7 & 156 \\ \text { 30-Jun-87 } & 2007 & & 12.1 & 13.4 & 157 \\ \text { 3-Jul-87 } & 2010 & 0745 & 12.4 & 12.9 & 155 \\ \text { 11-Jul-87 } & 2018 & 0950 & 10.6 & 15.6 & 159 \\ & & & & & \\ \text { 14-Jul-87 } & 2021 & 1315 & 14.2 & 10.9 & 150 \\ \text { 18-Jul-87 } & 2025 & 1300 & 10.5 & 17.6 & 178 \\ \text { 25-Jul-87 } & 2032 & 1030 & 13.5 & 11.1 & 145 \\ \text { 31-Jul-87 } & 2038 & 0900 & 13.9 & 10.6 & 142 \\ \text { 8-Aug-87 } & 2046 & 1050 & 16.4 & 8.1 & 128 \\ & & & & & \\ \text { 15-Aug-87 } & 2053 & 1320 & 17.1 & 7.5 & 124 \\ \text { 19-Aug-87 } & 2057 & 1645 & 17.9 & 7.0 & 121 \\ \text { 22-Aug-87 } & 2060 & 0830 & 19.0 & 6.7 & 122 \\ \text { 28-Aug-87 } & 2066 & 1045 & 18.9 & 6.9 & 126 \\ \text { 31-Aug-87 } & 2069 & & 19.1 & 6.5 & 121 \\ \text { 5-Sep-87 } & 2074 & 1530 & 19.4 & 6.9 & 134 \\ \text { 11-Sep-87 } & 2080 & 1230 & 20.2 & 6.3 & 124 \\ \text { 27-Sep-87 } & 2096 & 1430 & 22.5 & 5.7 & 125 \\ \text { 30-Sep-87 } & 2099 & & 22.7 & 5.4 & 121\end{array}$

Water year 1988:

$\begin{array}{llllll}\text { 9-Oct-87 } & 2108 & 1500 & 23.1 & 5.2 & 120 \\ \text { 20-Oct-87 } & 2119 & 1630 & 22.6 & 4.7 & 107 \\ \text { 31-Oct-87 } & 2130 & & 21.4 & 5.1 & 108 \\ \text { 28-Nov-87 } & 2158 & 1520 & 18.3 & 5.9 & 107 \\ \text { 30-Nov-87 } & 2160 & & 18.6 & 6.0 & 112 \\ & & & & & \\ \text { 16-Dec-87 } & 2176 & 1200 & 21.2 & 7.1 & 150 \\ \text { 30-Dec-87 } & 2190 & 1315 & 20.4 & 7.2 & 147 \\ \text { 31-Dec-87 } & 2191 & & 20.4 & 7.3 & 148 \\ \text { 29-Jan-88 } & 2220 & 1510 & 20.1 & 8.8 & 177 \\ \text { 31-Jan-88 } & 2222 & & 20.3 & 8.8 & 177 \\ & & & & & \\ \text { 23-Feb-88 } & 2245 & 1500 & 22.6 & 8.0 & 182 \\ \text { 24-Feb-88 } & 2246 & 1535 & 20.6 & 8.6 & 176 \\ \text { 29-Feb-88 } & 2251 & & 20.8 & 8.3 & 173 \\ \text { 19-Mar-88 } & 2270 & 1630 & 21.6 & 7.5 & 161 \\ \text { 30-Mar-88 } & 2281 & 0900 & 21.6 & 7.8 & 168 \\ & & & & & \\ \text { 31-Mar-88 } & 2282 & & 21.2 & 8.3 & 175 \\ \text { 13-Apr-88 } & 2295 & 0930 & 15.7 & 14.6 & 229 \\ \text { 26-Apr-88 } & 2308 & 1000 & 13.6 & 17.4 & 237 \\ \text { 30-Apr-88 } & 2312 & & 12.6 & 17.9 & 227 \\ \text { 3-May-88 } & 2315 & 1050 & 11.9 & 18.4 & 218 \\ & & & & & \\ \text { 9-May-88 } & 2321 & 1130 & 11.0 & 20.6 & 227 \\ \text { 15-May-88 } & 2327 & 1410 & 4.9 & 61.2 & 300 \\ \text { 22-May-88 } & 2334 & 1245 & 4.3 & 86.1 & 371 \\ \text { 29-May-88 } & 2341 & 0645 & 3.5 & 86.5 & 303 \\ \text { 31-May-88 } & 2343 & & 3.7 & 88.9 & 326 \\ \text { 5-Jun-88 } & 2348 & 1220 & 4.1 & 94.9 & 386 \\ \text { 12-Jun-88 } & 2355 & 1605 & 5.5 & 49.6 & 273 \\ \text { 19-Jun-88 } & 2362 & 0930 & 7.2 & 29.7 & 214 \\ \text { 26-Jun-88 } & 2369 & 0745 & 9.8 & 18.7 & 183 \\ \text { 30-Jun-88 } & 2373 & & 10.7 & 15.1 & 161 \\ & & & & & \\ \text { 3-Jul-88 } & 2376 & 0830 & 11.3 & 12.5 & 141\end{array}$




\begin{tabular}{|c|c|c|c|c|}
\hline \multirow{2}{*}{$\begin{array}{l}\text { Day- } \\
\text { month- } \\
\text { year }\end{array}$} & \multirow{2}{*}{$\begin{array}{l}\text { Date } 1 \text { Time } 2 \\
\text { No. }\end{array}$} & \multicolumn{3}{|c|}{ Instantaneous values } \\
\hline & & $\begin{array}{c}\text { Chloride } \\
\mathrm{mg} / \mathrm{L}\end{array}$ & $\begin{array}{c}\text { Discharge } \\
\mathrm{m}^{3 / \mathrm{s}}\end{array}$ & $\begin{array}{c}\mathrm{Cl} \text { flux } \\
\mathrm{g} / \mathrm{s}\end{array}$ \\
\hline
\end{tabular}

$\begin{array}{llllll}\text { 10-Jul-88 } & 2383 & 1015 & 12.9 & 10.9 & 140 \\ \text { 17-Jul-88 } & 2390 & 1000 & 15.0 & 8.3 & 124 \\ \text { 31-Jul-88 } & 2404 & & 17.4 & 6.7 & 117 \\ \text { 5-Aug-88 } & 2409 & 0900 & 18.3 & 6.1 & 112 \\ \text { 11-Aug-88 } & 2415 & 0915 & 19.8 & 5.8 & 114 \\ & & & & & \\ \text { 14-Aug-88 } & 2418 & 0945 & 19.7 & 5.8 & 114 \\ \text { 22-Aug-88 } & 2426 & 1000 & 22.3 & 5.2 & 116 \\ \text { 28-Aug-88 } & 2432 & 1330 & 22.5 & 5.2 & 116 \\ \text { 31-Aug-88 } & 2435 & & 22.8 & 5.1 & 117 \\ \text { 4-Sep-88 } & 2439 & 0945 & 23.3 & 5.1 & 119 \\ & & & & & \\ \text { 20-Sep-88 } & 2455 & 1145 & 24.5 & 5.0 & 123 \\ \text { 30-Sep-88 } & 2465 & & 24.7 & 5.1 & 125\end{array}$

Water year 1989:

$\begin{array}{lllrrr}\text { 7-Oct-88 } & 2472 & 1520 & 24.8 & 5.2 & 129 \\ \text { 20-Oct-88 } & 2485 & 1120 & 23.7 & 5.7 & 134 \\ \text { 31-Oct-88 } & 2496 & & 23.4 & 5.8 & 137 \\ \text { 10-Nov-88 } & 2506 & 1030 & 23.1 & 6.0 & 139 \\ \text { 30-Nov-88 } & 2526 & & 24.5 & 6.2 & 151 \\ & & & & & \\ \text { 16-Dec-88 } & 2542 & 1150 & 25.7 & 6.3 & 162 \\ \text { 31-Dec-88 } & 2557 & & 23.3 & 7.3 & 169 \\ \text { 8-Jan-89 } & 2565 & 1400 & 22.0 & 7.8 & 171 \\ \text { 31-Jan-89 } & 2588 & & 21.4 & 7.9 & 169 \\ \text { 12-Feb-89 } & 2600 & 1000 & 21.1 & 7.9 & 167 \\ & & & & & \\ \text { 26-Feb-89 } & 2614 & 1150 & 21.3 & 7.4 & 159 \\ \text { 28-Feb-89 } & 2616 & & 20.9 & 7.7 & 161 \\ \text { 5-Mar-89 } & 2621 & 1700 & 19.8 & 8.4 & 167 \\ \text { 26-Mar-89 } & 2642 & 1630 & 19.2 & 10.0 & 192 \\ \text { 31-Mar-89 } & 2647 & & 18.6 & 10.1 & 187 \\ & & & & & \\ \text { 10-Apr-89 } & 2657 & 1630 & 17.5 & 10.1 & 177 \\ \text { 18-Apr-89 } & 2665 & 1625 & 9.8 & 17.0 & 167 \\ \text { 30-Apr-89 } & 2677 & 1300 & 10.1 & 28.1 & 284 \\ \text { 7-May-89 } & 2684 & 1200 & 4.4 & 107.9 & 476 \\ \text { 17-May-89 } & 2694 & 0757 & 4.4 & 110.4 & 489 \\ \text { 21-May-89 } & 2698 & 1430 & 4.2 & 121.5 & 507 \\ \text { 29-May-89 } & 2706 & 1230 & 4.1 & 114.1 & 471 \\ \text { 31-May-89 } & 2708 & & 4.1 & 110.9 & 453 \\ \text { 4-Jun-89 } & 2712 & 0930 & 4.0 & 104.4 & 417 \\ \text { 11-Jun-89 } & 2719 & 0750 & 3.7 & 106.0 & 389 \\ & & & & & \\ \text { 18-Jun-89 } & 2726 & 1725 & 4.9 & 75.9 & 368 \\ \text { 25-Jun-89 } & 2733 & 0900 & 6.8 & 43.9 & 297 \\ \text { 30-Jun-89 } & 2738 & & 6.9 & 37.8 & 262 \\ \text { 2-Jul-89 } & 2740 & 0730 & 7.0 & 35.4 & 248 \\ \text { 9-Jul-89 } & 2747 & 1700 & 9.2 & 22.9 & 210 \\ \text { 16-Jul-89 } & 2754 & 0950 & 10.3 & 19.1 & 197 \\ \text { 23-Jul-89 } & 2761 & 0730 & 11.3 & 14.6 & 164 \\ \text { 31-Jul-89 } & 2769 & & 12.0 & 14.6 & 175 \\ \text { 2-Aug-89 } & 2771 & 1525 & 12.2 & 14.6 & 178 \\ \text { 6-Aug-89 } & 2775 & 0720 & 13.5 & 12.0 & 162 \\ & & & & & \\ \text { 13-Aug-89 } & 2782 & 0830 & 13.4 & 12.0 & 161 \\ \text { 20-Aug-89 } & 2789 & 0745 & 13.4 & 11.4 & 153 \\ \text { 27-Aug-89 } & 2796 & 1000 & 14.9 & 8.8 & 131 \\ \text { 31-Aug-89 } & 2800 & & 14.9 & 8.7 & 129 \\ \text { 10-Sep-89 } & 2810 & 1930 & 14.8 & 8.3 & 123 \\ & & & & & \\ \text { 24-Sep-89 } & 2824 & 1800 & 17.0 & 7.0 & 119 \\ \text { 30-Sep-89 } & 2830 & & 16.5 & 8.4 & 138\end{array}$

\begin{tabular}{lcccc}
\hline Day & Date 1 & Time 2 & \multicolumn{3}{c}{ Instantaneous values } \\
\cline { 3 - 4 } $\begin{array}{l}\text { month- } \\
\text { year }\end{array}$ & No. & $\begin{array}{c}\text { Chloride } \\
\mathrm{mg} / \mathrm{L}\end{array}$ & $\begin{array}{c}\text { Discharge } \\
\mathrm{m}^{3} / \mathrm{s}\end{array}$ & $\begin{array}{c}\mathrm{Cl} \text { flux } \\
\mathrm{g} / \mathrm{s}\end{array}$ \\
\hline \multicolumn{4}{c}{ Yellowstone River } \\
\hline
\end{tabular}

\section{Water Year 1983}

\begin{tabular}{|c|c|c|c|c|c|}
\hline $\begin{array}{l}\text { 30-Sep-82 } \\
5-\text { Oct-82 } \\
\text { 26-Oct-82 } \\
\text { 31-Oct-82 } \\
\text { 4-Nov-82 }\end{array}$ & $\begin{array}{l}273 \\
278 \\
299 \\
304 \\
308\end{array}$ & $\begin{array}{l}1715 \\
1645\end{array}$ & $\begin{array}{l}10.1 \\
10.0 \\
12.1 \\
11.5 \\
11.0\end{array}$ & $\begin{array}{l}73.1 \\
71.4 \\
53.8 \\
50.3 \\
47.6\end{array}$ & $\begin{array}{l}736 \\
714 \\
651 \\
578 \\
523\end{array}$ \\
\hline $\begin{array}{l}\text { 24-Nov-82 } \\
\text { 30-Nov-82 } \\
\text { 24-Dec-82 } \\
\text { 31-Dec-82 } \\
\text { 19-Jan-83 }\end{array}$ & $\begin{array}{l}328 \\
334 \\
358 \\
365 \\
384\end{array}$ & $\begin{array}{l}1444 \\
1327 \\
1100\end{array}$ & $\begin{array}{l}13.8 \\
13.8 \\
13.9 \\
14.7 \\
16.7\end{array}$ & $\begin{array}{l}36.5 \\
36.0 \\
33.7 \\
33.1 \\
31.4\end{array}$ & $\begin{array}{l}504 \\
497 \\
468 \\
485 \\
525\end{array}$ \\
\hline $\begin{array}{l}\text { 31-Jan-83 } \\
\text { 17-Feb-83 } \\
\text { 28-Feb-83 } \\
\text { 10-Mar-83 } \\
\text { 22-Mar-83 }\end{array}$ & $\begin{array}{l}396 \\
413 \\
424 \\
434 \\
446\end{array}$ & $\begin{array}{l}1645 \\
1645\end{array}$ & $\begin{array}{l}15.5 \\
13.9 \\
14.8 \\
15.7 \\
15.5\end{array}$ & $\begin{array}{l}31.0 \\
30.3 \\
30.0 \\
29.7 \\
27.2\end{array}$ & $\begin{array}{l}481 \\
421 \\
445 \\
467 \\
420\end{array}$ \\
\hline $\begin{array}{l}\text { 31-Mar-83 } \\
\text { 14-Apr-83 } \\
\text { 30-Apr-83 } \\
\text { 4-May-83 } \\
\text { 12-May-83 }\end{array}$ & $\begin{array}{l}455 \\
469 \\
485 \\
489 \\
497\end{array}$ & $\begin{array}{l}1230 \\
0900 \\
\\
1615 \\
1710\end{array}$ & $\begin{array}{l}15.0 \\
15.4 \\
12.4 \\
11.6 \\
11.2\end{array}$ & $\begin{array}{l}29.7 \\
26.8 \\
40.7 \\
44.2 \\
43.3\end{array}$ & $\begin{array}{l}446 \\
413 \\
503 \\
512 \\
485\end{array}$ \\
\hline $\begin{array}{l}\text { 17-May-83 } \\
\text { 31-May-83 } \\
\text { 1-Jun-83 } \\
\text { 15-Jun-83 } \\
\text { 21-Jun-83 }\end{array}$ & $\begin{array}{l}502 \\
516 \\
517 \\
531 \\
537\end{array}$ & $\begin{array}{l}1645 \\
\\
1400 \\
1535 \\
1430\end{array}$ & $\begin{array}{r}11.4 \\
3.5 \\
3.0 \\
3.2 \\
3.7\end{array}$ & $\begin{array}{r}41.6 \\
236.9 \\
250.9 \\
251.7 \\
241.0\end{array}$ & $\begin{array}{l}475 \\
835 \\
743 \\
811 \\
896\end{array}$ \\
\hline $\begin{array}{l}\text { 28-Jun-83 } \\
\text { 30-Jun-83 } \\
\text { 6-Jul-83 } \\
\text { 11-Jul-83 } \\
\text { 21-Jul-83 }\end{array}$ & $\begin{array}{l}544 \\
546 \\
552 \\
557 \\
567\end{array}$ & $\begin{array}{l}1545 \\
\\
1215 \\
1845 \\
1710\end{array}$ & $\begin{array}{l}3.4 \\
3.5 \\
3.8 \\
4.1 \\
5.4\end{array}$ & $\begin{array}{l}286.0 \\
277.2 \\
250.9 \\
261.9 \\
173.9\end{array}$ & $\begin{array}{r}972 \\
972 \\
961 \\
1077 \\
944\end{array}$ \\
\hline $\begin{array}{l}29-J u l-83 \\
31-J u l-83 \\
5 \text {-Aug-83 } \\
11-A u g-83 \\
19-A u g-83\end{array}$ & $\begin{array}{l}575 \\
577 \\
582 \\
588 \\
596\end{array}$ & $\begin{array}{l}1503 \\
\\
1127 \\
1810 \\
1630\end{array}$ & $\begin{array}{l}6.6 \\
6.6 \\
6.7 \\
7.4 \\
7.8\end{array}$ & $\begin{array}{r}140.5 \\
135.3 \\
122.3 \\
109.6 \\
93.4\end{array}$ & $\begin{array}{l}928 \\
896 \\
816 \\
811 \\
731\end{array}$ \\
\hline $\begin{array}{l}\text { 31-Aug-83 } \\
\text { 1-Sep-83 } \\
27-\text { Sep-83 } \\
30-\text { Sep-83 }\end{array}$ & $\begin{array}{l}608 \\
609 \\
635 \\
638\end{array}$ & $\begin{array}{l}1330 \\
1700\end{array}$ & $\begin{array}{l}8.5 \\
8.6 \\
9.9 \\
9.6\end{array}$ & $\begin{array}{l}76.2 \\
74.8 \\
51.5 \\
53.2\end{array}$ & $\begin{array}{l}651 \\
643 \\
510 \\
513\end{array}$ \\
\hline
\end{tabular}

Water year 1984:

$\begin{array}{lllrll}\text { 18-Oct-83 } & 656 & 1200 & 8.1 & 63.4 & 513 \\ \text { 31-Oct-83 } & 669 & & 10.0 & 56.9 & 571 \\ \text { 1-Nov-83 } & 670 & 1200 & 10.2 & 56.4 & 575 \\ \text { 15-Nov-83 } & 684 & 1100 & 9.4 & 57.2 & 538 \\ \text { 30-Nov-83 } & 699 & & 12.0 & 50.6 & 607 \\ & & & & & \\ \text { 8-Dec-83 } & 707 & 1200 & 13.4 & 47.0 & 630 \\ \text { 31-Dec-83 } & 730 & & 13.0 & 39.5 & 512 \\ \text { 3-Jan-84 } & 733 & 1625 & 12.9 & 38.5 & 497 \\ \text { 31-Jan-84 } & 761 & & 13.5 & 33.8 & 454 \\ \text { 7-Feb-84 } & 768 & 0915 & 13.6 & 32.6 & 443 \\ & & & & & \\ \text { 27-Feb-84 } & 788 & 1645 & 14.0 & 30.3 & 424 \\ \text { 29-Feb-84 } & 790 & & 14.1 & 30.4 & 428 \\ \text { 13-Mar-84 } & 803 & 1630 & 14.6 & 30.9 & 451 \\ \text { 31-Mar-84 } & 821 & & 15.0 & 29.7 & 446 \\ \text { 3-Apr-84 } & 824 & 1145 & 15.1 & 29.4 & 445\end{array}$




\begin{tabular}{lcccc}
\hline $\begin{array}{l}\text { Day- } \\
\text { month- }\end{array}$ & Date 1 & Time 2 & \multicolumn{3}{c}{ Instantaneous values } \\
\cline { 3 - 4 } year & No. & Chloride & Discharge & $\mathrm{Cl} \mathrm{flux}$ \\
$\mathrm{mg} / \mathrm{L}$ & $\mathrm{m} 3 / \mathrm{s}$ & $\mathrm{g} / \mathrm{s}$ \\
\hline \multicolumn{4}{c}{} & Yellowstone River \\
\hline
\end{tabular}

$\begin{array}{lllllr}\text { 10-Apr-84 } & 831 & 0920 & 13.8 & 32.0 & 442 \\ \text { 26-Apr-84 } & 847 & 1645 & 11.1 & 43.6 & 484 \\ \text { 30-Apr-84 } & 851 & & 10.7 & 42.3 & 452 \\ \text { 2-May-84 } & 853 & 1515 & 10.5 & 41.6 & 437 \\ \text { 9-May-84 } & 860 & 1035 & 11.0 & 43.3 & 477 \\ & & & & & \\ \text { 16-May-84 } & 867 & 0820 & 2.1 & 337.0 & 694 \\ \text { 23-May-84 } & 874 & 1730 & 2.8 & 214.1 & 606 \\ \text { 30-May-84 } & 881 & 1624 & 2.5 & 297.3 & 743 \\ \text { 31-May-84 } & 882 & & 2.6 & 292.4 & 766 \\ \text { 6-Jun-84 } & 888 & 2043 & 3.3 & 262.8 & 878 \\ & & & & & \\ \text { 16-Jun-84 } & 898 & 0700 & 2.4 & 379.4 & 911 \\ \text { 22-Jun-84 } & 904 & 2145 & 2.9 & 342.6 & 987 \\ \text { 30-Jun-84 } & 912 & 2150 & 3.3 & 385.1 & 1271 \\ \text { 7-Jul-84 } & 919 & 1050 & 3.7 & 288.8 & 1054 \\ \text { 14-Jul-84 } & 926 & 2000 & 5.1 & 211.0 & 1076 \\ & & & & & \\ \text { 22-Jul-84 } & 934 & 0930 & 10.7 & 184.9 & 1979 \\ \text { 28-Jul-84 } & 940 & 2030 & 6.5 & 165.9 & 1075 \\ \text { 31-Jul-84 } & 943 & & 6.3 & 155.0 & 979 \\ \text { 4-Aug-84 } & 947 & 2001 & 6.1 & 140.5 & 857 \\ \text { 18-Aug-84 } & 961 & 2120 & 6.9 & 102.8 & 709 \\ & & & & & \\ \text { 25-Aug-84 } & 968 & 2010 & 7.1 & 18.5 & 655 \\ \text { 31-Aug-84 } & 974 & 2015 & 8.0 & 80.7 & 646 \\ \text { 13-Sep-84 } & 987 & 1730 & 8.4 & 64.3 & 540 \\ \text { 30-Sep-84 } & 1004 & & 9.0 & 57.1 & 512\end{array}$

Water year 1985:

$\begin{array}{lllrll}\text { 1-Oct-84 } & 1005 & 1930 & 9.0 & 56.6 & 510 \\ \text { 2-Oct-84 } & 1006 & 1600 & 9.4 & 55.9 & 525 \\ \text { 13-Oct-84 } & 1017 & 1205 & 10.7 & 49.0 & 524 \\ \text { 27-Oct-84 } & 1031 & 1530 & 11.1 & 42.8 & 475 \\ \text { 31-Oct-84 } & 1035 & & 11.2 & 42.5 & 475 \\ & & & & & \\ \text { 12-Nov-84 } & 1047 & 1655 & 11.4 & 41.9 & 478 \\ \text { 14-Nov-84 } & 1049 & 1200 & 11.7 & 41.7 & 488 \\ \text { 30-Nov-84 } & 1065 & & 12.6 & 37.4 & 472 \\ \text { 14-Dec-84 } & 1079 & 1530 & 13.4 & 33.7 & 452 \\ \text { 31-Dec-84 } & 1096 & & 13.8 & 30.9 & 426 \\ & & & & & \\ \text { 12-Jan-85 } & 1108 & 1730 & 14.1 & 28.9 & 407 \\ \text { 24-Jan-85 } & 1120 & 1435 & 13.5 & 27.4 & 370 \\ \text { 30-Jan-85 } & 1126 & 1630 & 17.5 & 26.9 & 471 \\ \text { 31-Jan-85 } & 1127 & & 17.3 & 27.1 & 468 \\ \text { 17-Feb-85 } & 1144 & 0845 & 13.5 & 29.7 & 401 \\ & & & & & \\ \text { 28-Feb-85 } & 1155 & & 14.4 & 28.6 & 411 \\ \text { 3-Mar-85 } & 1158 & 1800 & 14.6 & 28.3 & 413 \\ \text { 12-Mar-85 } & 1167 & 1430 & 13.6 & 28.3 & 385 \\ \text { 17-Mar-85 } & 1172 & 1130 & 13.5 & 29.2 & 394 \\ \text { 31-Mar-85 } & 1186 & & 10.8 & 30.2 & 326 \\ & & & & & \\ \text { 1-Apr-85 } & 1187 & 1630 & 10.6 & 30.3 & 321 \\ \text { 14-Apr-85 } & 1200 & 1630 & 9.1 & 51.0 & 464 \\ \text { 15-Apr-85 } & 1201 & 1530 & 7.7 & 59.0 & 455 \\ \text { 28-Apr-85 } & 1214 & 2045 & 8.9 & 50.2 & 447 \\ \text { 30-Apr-85 } & 1216 & & 8.4 & 60.8 & 509 \\ \text { 14-May-85 } & 1230 & 2200 & 4.6 & 135.2 & 622 \\ \text { 24-May-85 } & 1240 & 2100 & 2.5 & 223.8 & 703 \\ \text { 31-May-85 } & 1247 & & 3.6 & 215.6 & 795 \\ \text { 1-Jun-85 } & 1248 & 1430 & 3.7 & 215.6 & 798 \\ \text { 3-Jun-85 } & 1250 & 1445 & 3.9 & 209.6 & 817 \\ & & & & & \\ \text { 8-Jun-85 } & 1255 & 1750 & 4.7 & 341.5 & 1544\end{array}$

Day Date 1 Time 2 Instantaneous values month- No. Chloride Discharge Cl flux year $\mathrm{mg} / \mathrm{L} \quad \mathrm{m} 3 / \mathrm{s} \quad \mathrm{g} / \mathrm{s}$

\section{Yellowstone River}

$\begin{array}{lrrrrr}\text { 15-Jun-85 } & 1262 & 1920 & 5.0 & 214.1 & 1073 \\ \text { 22-Jun-85 } & 1269 & 1930 & 5.6 & 171.9 & 958 \\ \text { 29-Jun-85 } & 1276 & 2000 & 5.6 & 150.1 & 846 \\ \text { 30-Jun-85 } & 1277 & & 5.7 & 147.1 & 835 \\ \text { 5-Jul-85 } & 1282 & 1230 & 5.8 & 132.3 & 773 \\ \text { 7-Jul-85 } & 1284 & 2130 & 6.9 & 126.7 & 873 \\ & & & & & \\ \text { 8-Jul-85 } & 1285 & 1135 & 6.0 & 125.0 & 745 \\ \text { 20-Jul-85 } & 1297 & 2030 & 7.3 & 100.7 & 734 \\ \text { 28-Jul-85 } & 1305 & 2030 & 7.4 & 88.6 & 653 \\ \text { 31-Jul-85 } & 1308 & & 7.6 & 89.0 & 673 \\ \text { 4-Aug-85 } & 1312 & 1900 & 7.8 & 89.6 & 700 \\ \text { 10-Aug-85 } & 1318 & 2020 & 9.2 & 71.9 & 660 \\ \text { 17-Aug-85 } & 1325 & 1920 & 9.4 & 64.1 & 603 \\ \text { 19-Aug-85 } & 1327 & 1130 & 8.4 & 63.0 & 529 \\ \text { 24-Aug-85 } & 1332 & 1720 & 9.2 & 56.2 & 517 \\ \text { 31-Aug-85 } & 1339 & 1920 & 9.8 & 51.5 & 505 \\ \text { 19-Sep-85 } & 1358 & 1820 & 9.3 & 53.9 & 501 \\ \text { 30-Sep-85 } & 1369 & & 11.0 & 45.9 & 503\end{array}$

Water year 1986:

\begin{tabular}{|c|c|c|c|c|c|}
\hline $\begin{array}{l}\text { 1-Oct-85 } \\
3-\text { Oct-85 } \\
4-\text { Oct-85 } \\
17-\text { Oct-85 } \\
31-\text { Oct-85 }\end{array}$ & $\begin{array}{l}1370 \\
1372 \\
1373 \\
1386 \\
1400\end{array}$ & $\begin{array}{l}1700 \\
1725 \\
0845 \\
1450 \\
1600\end{array}$ & $\begin{array}{l}11.1 \\
11.4 \\
10.2 \\
12.3 \\
14.0\end{array}$ & $\begin{array}{l}45.2 \\
43.7 \\
43.3 \\
40.0 \\
39.7\end{array}$ & $\begin{array}{l}502 \\
499 \\
442 \\
492 \\
556\end{array}$ \\
\hline $\begin{array}{l}\text { 30-Nov-85 } \\
\text { 10-Dec-85 } \\
\text { 31-Dec-85 } \\
\text { 31-Jan-86 } \\
\text { 6-Feb-86 }\end{array}$ & $\begin{array}{l}1430 \\
1440 \\
1461 \\
1492 \\
1498\end{array}$ & 0845 & $\begin{array}{l}14.5 \\
14.6 \\
14.5 \\
14.2 \\
14.2\end{array}$ & $\begin{array}{l}27.8 \\
23.9 \\
24.1 \\
27.9 \\
29.2\end{array}$ & $\begin{array}{l}402 \\
349 \\
348 \\
397 \\
415\end{array}$ \\
\hline $\begin{array}{l}\text { 9-Feb-86 } \\
\text { 28-Feb-86 } \\
\text { 6-Mar-86 } \\
\text { 20-Mar-86 } \\
\text { 30-Mar-86 }\end{array}$ & $\begin{array}{l}1501 \\
1520 \\
1526 \\
1540 \\
1550\end{array}$ & $\begin{array}{l}0900 \\
1630 \\
1000 \\
1130\end{array}$ & \begin{tabular}{r|r|}
15.4 \\
13.0 \\
12.3 \\
12.3 \\
9.7
\end{tabular} & $\begin{array}{l}24.1 \\
33.3 \\
36.2 \\
34.6 \\
52.5\end{array}$ & $\begin{array}{l}371 \\
434 \\
445 \\
426 \\
510\end{array}$ \\
\hline $\begin{array}{l}\text { 31-Mar-86 } \\
\text { 15-Apr-86 } \\
\text { 29-Apr-86 } \\
\text { 30-Apr-86 } \\
\text { 1-May-86 }\end{array}$ & $\begin{array}{l}1551 \\
1566 \\
1580 \\
1581 \\
1582\end{array}$ & $\begin{array}{l}1630 \\
1400\end{array}$ & $\begin{array}{l}9.6 \\
8.5 \\
4.6 \\
6.0 \\
7.4\end{array}$ & $\begin{array}{l}52.8 \\
56.6 \\
69.1 \\
68.5 \\
67.9\end{array}$ & $\begin{array}{l}508 \\
481 \\
318 \\
411 \\
503\end{array}$ \\
\hline $\begin{array}{l}\text { 30-May-86 } \\
\text { 31-May-86 } \\
\text { 1-Jun-86 } \\
\text { 4-Jun-86 } \\
\text { 10-Jun-86 }\end{array}$ & $\begin{array}{l}1611 \\
1612 \\
1613 \\
1616 \\
1622\end{array}$ & $\begin{array}{l}1000 \\
1030 \\
1030 \\
1730\end{array}$ & $\begin{array}{l}3.2 \\
2.6 \\
2.0 \\
4.1 \\
2.9\end{array}$ & $\begin{array}{l}492.7 \\
532.4 \\
572.0 \\
567.5 \\
462.4\end{array}$ & $\begin{array}{l}1577 \\
1384 \\
1144 \\
2327 \\
1341\end{array}$ \\
\hline $\begin{array}{l}\text { 12-Jun-86 } \\
\text { 19-Jun-86 } \\
\text { 26-Jun-86 } \\
\text { 30-Jun-86 } \\
\text { 3-Jul-86 }\end{array}$ & $\begin{array}{l}1624 \\
1631 \\
1638 \\
1642 \\
1645\end{array}$ & $\begin{array}{l}1030 \\
1630 \\
1730\end{array}$ & $\begin{array}{l}4.2 \\
5.2 \\
5.2 \\
5.1 \\
5.1\end{array}$ & $\begin{array}{l}497.2 \\
442.3 \\
329.0 \\
290.2 \\
261.1\end{array}$ & $\begin{array}{l}2088 \\
2300 \\
1711 \\
1493 \\
1332\end{array}$ \\
\hline $\begin{array}{l}\text { 11-Jul-86 } \\
\text { 17-Jul-86 } \\
\text { 22-Jul-86 } \\
\text { 25-Jul-86 } \\
\text { 31-Jul-86 }\end{array}$ & $\begin{array}{l}1653 \\
1659 \\
1664 \\
1667 \\
1673\end{array}$ & $\begin{array}{l}16330 \\
1850 \\
1530 \\
1720 \\
1630\end{array}$ & $\begin{array}{l}5.4 \\
7.3 \\
5.6 \\
6.8 \\
7.7\end{array}$ & $\begin{array}{l}230.5 \\
188.4 \\
160.1 \\
162.1 \\
139.2\end{array}$ & $\begin{array}{r}1245 \\
1375 \\
897 \\
1102 \\
1072\end{array}$ \\
\hline $\begin{array}{l}8 \text {-Aug-86 } \\
\text { 15-Aug-86 } \\
30 \text {-Aug-86 }\end{array}$ & $\begin{array}{l}1681 \\
1688 \\
1703\end{array}$ & $\begin{array}{l}10330 \\
1920 \\
1420\end{array}$ & $\begin{array}{l}8.6 \\
8.0 \\
8.0\end{array}$ & $\begin{array}{r}116.9 \\
99.7 \\
81.4\end{array}$ & $\begin{array}{r}1006 \\
798 \\
652\end{array}$ \\
\hline
\end{tabular}




\begin{tabular}{|c|c|c|c|c|}
\hline \multirow{2}{*}{$\begin{array}{l}\text { Day- } \\
\text { month- } \\
\text { year }\end{array}$} & \multirow{2}{*}{$\begin{array}{l}\text { Date } 1 \text { Time } 2 \\
\text { No. }\end{array}$} & \multicolumn{3}{|c|}{ Instantaneous values } \\
\hline & & $\begin{array}{c}\text { Chloride } \\
\mathrm{mg} / \mathrm{L}\end{array}$ & $\begin{array}{c}\text { Discharge } \\
\mathrm{m}^{3 / \mathrm{s}}\end{array}$ & $\begin{array}{c}\mathrm{Cl} \text { flux } \\
\mathrm{g} / \mathrm{s}\end{array}$ \\
\hline \multicolumn{5}{|c|}{ Yellowstone River } \\
\hline
\end{tabular}

$\begin{array}{llllll}\text { 31-Aug-86 } & 1704 & & 8.1 & 80.2 & 649 \\ \text { 4-Sep-86 } & 1708 & 1020 & 8.5 & 77.4 & 639 \\ \text { 23-Sep-86 } & 1727 & 1105 & 9.1 & 62.7 & 567 \\ \text { 30-Sep-86 } & 1734 & & 9.6 & 58.8 & 563\end{array}$

Water year 1987:

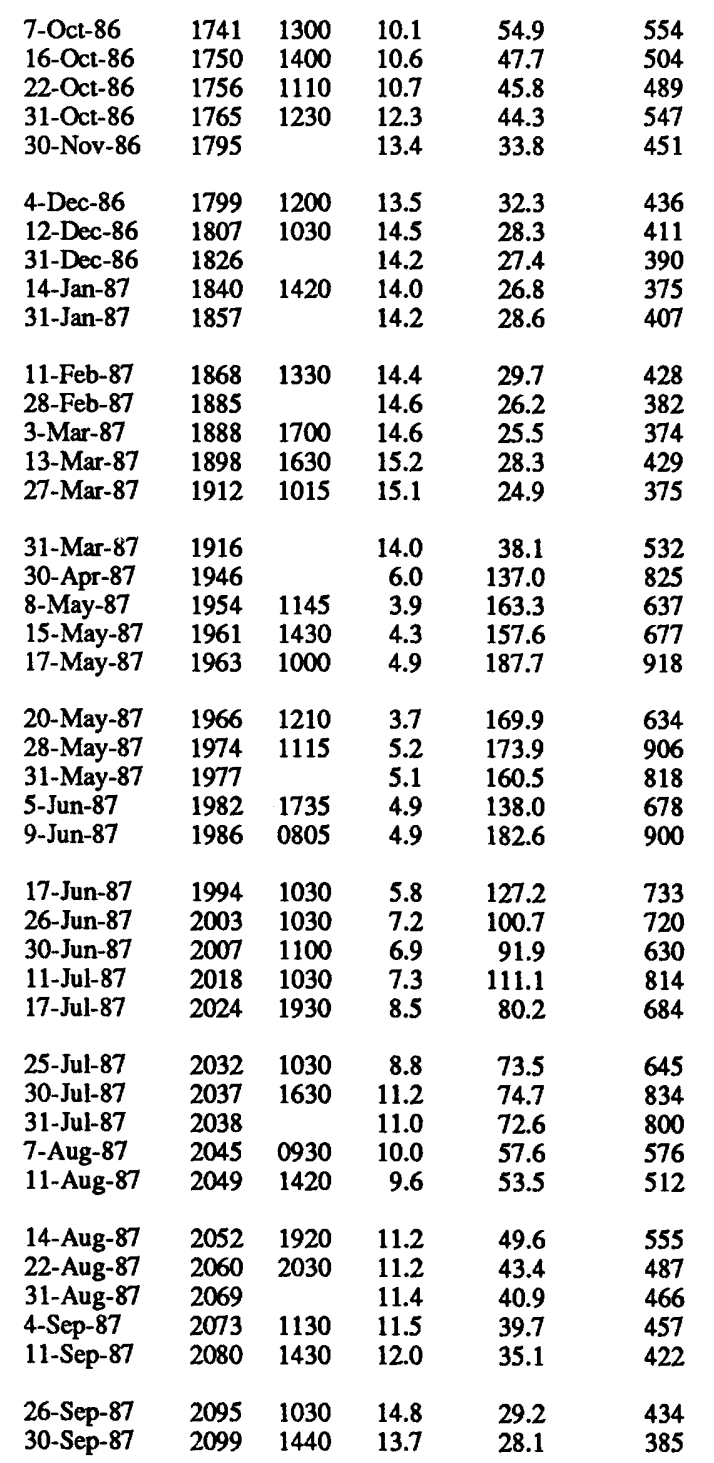

Water year 1988:

$\begin{array}{llllll}\text { 10-Oct-87 } & 2109 & 1200 & 15.1 & 24.7 & 372 \\ \text { 24-Oct-87 } & 2123 & 1300 & 16.2 & 22.1 & 358 \\ \text { 31-Oct-87 } & 2130 & & 16.0 & 22.8 & 363 \\ \text { 4-Nov-87 } & 2134 & 1420 & 15.9 & 23.1 & 366 \\ \text { 6-Nov-87 } & 2136 & 1650 & 16.8 & 21.5 & 361 \\ & & & & & \\ \text { 30-Nov-87 } & 2160 & & 18.9 & 21.3 & 403 \\ \text { 7-Dec-87 } & 2167 & 1240 & 19.6 & 21.2 & 415\end{array}$

\begin{tabular}{|c|c|c|c|c|c|}
\hline Day & Date 1 & Time 2 & Inste & Intaneous v & lues \\
\hline $\begin{array}{l}\text { month- } \\
\text { year }\end{array}$ & No. & & $\begin{array}{c}\text { Chloride } \\
\mathrm{mg} / \mathrm{L}\end{array}$ & $\begin{array}{c}\text { Discharge } \\
\mathrm{m}^{3 / \mathrm{s}}\end{array}$ & $\begin{array}{c}\mathrm{Cl} \text { flux } \\
\mathrm{g} / \mathrm{s}\end{array}$ \\
\hline
\end{tabular}

\section{Yellowstone River}

$\begin{array}{lllrrl}\text { 15-Dec-87 } & 2175 & 1000 & 21.8 & 20.8 & 453 \\ \text { 31-Dec-87 } & 2191 & & 23.5 & 18.2 & 426 \\ \text { 4-Jan-88 } & 2195 & 1430 & 23.9 & 17.5 & 418 \\ \text { 27-Jan-88 } & 2218 & 1010 & 22.9 & 13.5 & 308 \\ \text { 29-Jan-88 } & 2220 & 1620 & 23.1 & 13.5 & 310 \\ \text { 31-Jan-88 } & 2222 & & 22.8 & 13.7 & 314 \\ \text { 29-Feb-88 } & 2251 & 0900 & 19.5 & 17.9 & 348 \\ & & & & & \\ \text { 18-Mar-88 } & 2269 & 1620 & 18.3 & 19.9 & 364 \\ \text { 31-Mar-88 } & 2282 & 1015 & 14.2 & 22.3 & 317 \\ \text { 13-Apr-88 } & 2295 & 1230 & 12.4 & 37.8 & 469 \\ \text { 29-Apr-88 } & 2311 & 1520 & 9.2 & 54.2 & 496 \\ \text { 4-May-88 } & 2316 & 1410 & 9.3 & 48.6 & 452 \\ & & & & & \\ \text { 12-May-88 } & 2324 & 1020 & 3.7 & 132.3 & 490 \\ \text { 20-May-88 } & 2332 & 1620 & 2.9 & 154.4 & 446 \\ \text { 31-May-88 } & 2343 & & 4.2 & 210.5 & 877 \\ \text { 1-Jun-88 } & 2344 & 1620 & 4.3 & 215.6 & 923 \\ \text { 7-Jun-88 } & 2350 & 0900 & 2.4 & 324.5 & 776 \\ & & & & & \\ \text { 24-Jun-88 } & 2367 & 1030 & 5.3 & 151.9 & 805 \\ \text { 26-Jun-88 } & 2369 & 1420 & 6.5 & 140.4 & 913 \\ \text { 30-Jun-88 } & 2373 & & 7.0 & 120.8 & 846 \\ \text { 4-Jul-88 } & 2377 & 1200 & 7.5 & 101.2 & 759 \\ \text { 11-Jul-88 } & 2384 & 1400 & 9.4 & 83.2 & 782 \\ \text { 20-Jul-88 } & 2393 & 1100 & 8.1 & 66.4 & 538 \\ \text { 22-Jul-88 } & 2395 & 1020 & 9.7 & 64.1 & 622 \\ \text { 29-Jul-88 } & 2402 & 2020 & 10.3 & 58.0 & 597 \\ \text { 31-Jul-88 } & 2404 & & 10.4 & 56.0 & 580 \\ \text { 11-Aug-88 } & 2415 & 1625 & 10.7 & 44.9 & 481 \\ & & & & & \\ \text { 19-Aug-88 } & 2423 & 0820 & 13.1 & 37.8 & 495 \\ \text { 31-Aug-88 } & 2435 & 0940 & 12.1 & 30.6 & 371 \\ \text { 1-Sep-88 } & 2436 & 1620 & 12.7 & 29.7 & 377 \\ \text { 10-Sep-88 } & 2445 & 1200 & 14.1 & 27.0 & 381 \\ \text { 25-Sep-88 } & 2460 & 1750 & 17.2 & 24.5 & 421 \\ & & & & & \\ \text { 30-Sep-88 } & 2465 & & 16.3 & 23.6 & 384 \\ & & & & & \end{array}$

Water year 1989:

$\begin{array}{llllll}\text { 4-Oct-88 } & 2469 & 1230 & 15.5 & 23.3 & 361 \\ \text { 13-Oct-88 } & 2478 & 1420 & 16.4 & 22.1 & 363 \\ \text { 24-Oct-88 } & 2489 & 1225 & 18.4 & 21.4 & 393 \\ \text { 31-Oct-88 } & 2496 & 1500 & 16.8 & 19.9 & 334 \\ \text { 16-Nov-88 } & 2512 & 1600 & 17.5 & 19.4 & 339 \\ & & & & & \\ \text { 30-Nov-88 } & 2526 & & 17.8 & 19.3 & 342 \\ \text { 8-Dec-88 } & 2534 & 1130 & 17.9 & 19.2 & 344 \\ \text { 11-Dec-88 } & 2537 & 1530 & 18.8 & 19.4 & 364 \\ \text { 31-Dec-88 } & 2557 & & 21.5 & 16.5 & 354 \\ \text { 9-Jan-89 } & 2566 & 1700 & 22.7 & 15.1 & 344 \\ \text { 24-Jan-89 } & 2581 & 1630 & 23.5 & 13.2 & 309 \\ \text { 31-Jan-89 } & 2588 & & 23.7 & 13.2 & 314 \\ \text { 10-Feb-89 } & 2598 & 1230 & 24.1 & 13.3 & 321 \\ \text { 13-Feb-89 } & 2601 & 1545 & 24.6 & 14.7 & 362 \\ \text { 28-Feb-89 } & 2616 & & 21.2 & 14.0 & 296 \\ & & & & & \\ \text { 7-Mar-89 } & 2623 & 1630 & 19.6 & 13.6 & 266 \\ \text { 7-Mar-89 } & 2623 & 1315 & 24.8 & 13.3 & 330 \\ \text { 15-Mar-89 } & 2631 & 1400 & 19.7 & 17.2 & 338 \\ \text { 22-Mar-89 } & 2638 & 1730 & 15.9 & 18.5 & 294 \\ \text { 31-Mar-89 } & 2647 & & 14.8 & 24.3 & 358 \\ & & & & & \\ \text { 9-Apr-89 } & 2656 & 1030 & 13.6 & 30.0 & 408 \\ \text { 10-Apr-89 } & 2657 & 1400 & 14.0 & 26.4 & 370\end{array}$




\begin{tabular}{|c|c|c|c|c|c|}
\hline \multirow{2}{*}{$\begin{array}{l}\text { Day- } \\
\text { month- } \\
\text { year }\end{array}$} & \multirow{2}{*}{\multicolumn{2}{|c|}{$\begin{array}{l}\text { Date } 1 \text { Time } 2 \\
\text { No. }\end{array}$}} & \multicolumn{3}{|c|}{ Instantaneous values } \\
\hline & & & $\begin{array}{l}\text { Chloride } \\
\mathrm{mg} / \mathrm{L}\end{array}$ & $\begin{array}{c}\text { Discharge } \\
\mathrm{m} 3 / \mathbf{s}\end{array}$ & $\begin{array}{c}\mathrm{Cl} \text { flux } \\
\mathrm{g} / \mathrm{s}\end{array}$ \\
\hline \multicolumn{6}{|c|}{ Yellowstone River } \\
\hline $\begin{array}{l}\text { 29-Apr-89 } \\
\text { 30-Apr-89 } \\
\text { 10-May-89 } \\
\text { 11-May-89 } \\
\text { 31-May-89 }\end{array}$ & $\begin{array}{l}2676 \\
2677 \\
2687 \\
2688 \\
2708\end{array}$ & $\begin{array}{l}1430 \\
1200 \\
1920\end{array}$ & $\begin{array}{l}3.5 \\
3.4 \\
2.9 \\
3.8 \\
3.2\end{array}$ & $\begin{array}{r}75.6 \\
99.9 \\
342.6 \\
323.7 \\
340.1\end{array}$ & $\begin{array}{r}262 \\
342 \\
1004 \\
1233 \\
1075\end{array}$ \\
\hline $\begin{array}{l}\text { 9-Jun-89 } \\
\text { 14-Jun-89 } \\
\text { 30-Jun-89 } \\
\text { 3-Jul-89 } \\
\text { 11-Jul-89 }\end{array}$ & $\begin{array}{l}2717 \\
2722 \\
2738 \\
2741 \\
2749\end{array}$ & $\begin{array}{l}1000 \\
1625 \\
1710 \\
1530 \\
0900\end{array}$ & $\begin{array}{l}2.9 \\
4.1 \\
5.4 \\
4.7 \\
7.3\end{array}$ & $\begin{array}{l}347.4 \\
300.7 \\
208.1 \\
193.4 \\
165.9\end{array}$ & $\begin{array}{r}997 \\
1230 \\
1124 \\
899 \\
1213\end{array}$ \\
\hline $\begin{array}{l}\text { 13-Jul-89 } \\
\text { 28-Jul-89 } \\
\text { 3-Aug-89 } \\
\text { 10-Aug-89 } \\
\text { 18-Aug-89 }\end{array}$ & $\begin{array}{l}2751 \\
2766 \\
2772 \\
2779 \\
2787\end{array}$ & $\begin{array}{l}1000 \\
2200 \\
1445 \\
1410 \\
1600\end{array}$ & $\begin{array}{l}7.8 \\
7.9 \\
8.4 \\
8.7 \\
9.3\end{array}$ & $\begin{array}{r}165.4 \\
111.6 \\
92.3 \\
79.3 \\
68.0\end{array}$ & $\begin{array}{r}1285 \\
878 \\
774 \\
693 \\
630\end{array}$ \\
\hline $\begin{array}{l}\text { 25-Aug-89 } \\
\text { 28-Aug-89 } \\
\text { 31-Aug-89 } \\
12-\text { Sep-89 } \\
\text { 30-Sep-89 }\end{array}$ & $\begin{array}{l}2794 \\
2797 \\
2800 \\
2812 \\
2830\end{array}$ & $\begin{array}{l}1515 \\
1630 \\
1245 \\
1430\end{array}$ & $\begin{array}{r}9.9 \\
11.3 \\
10.4 \\
10.9 \\
11.3\end{array}$ & $\begin{array}{l}64.0 \\
41.1 \\
56.6 \\
46.2 \\
45.5\end{array}$ & $\begin{array}{l}630 \\
464 \\
589 \\
501 \\
513\end{array}$ \\
\hline
\end{tabular}





\section{SELECTED SERIES OF U.S. GEOLOGICAL SURVEY PUBLICATIONS}

\section{Perlodicals}

Earthquakes \& Volcanoes (issued bimonthly).

Preliminary Determination of Epicenters (issued monthly).

\section{Technical Books and Reports}

Professional Papers are mainly comprehensive scientific reports of wide and lasting interest and importance to professional scientists and engineers. Included are reports on the results of resource studies and of topographic, hydrologic, and geologic investigations. They also include collections of related papers addressing different aspects of a single scientific topic.

Bulletins contain significant data and interpretations that are of lasting scientific interest but are generally more limited in scope or geographic coverage than Professional Papers. They include the results of resource studies and of geologic and topographic investigations; as well as collections of short papers related to a specific topic.

Water-Supply Papers are comprehensive reports that present significant interpretive results of hydrologic investigations of wide interest to professional geologists, hydrologists, and engineers. The series covers investigations in all phases of hydrology, including hydrogeology, availability of water, quality of water, and use of water.

Circulars present administrative information or important scientific information of wide popular interest in a format designed for distribution at no cost to the public. Information is usually of short-term interest.

Water-Resources Investigations Reports are papers of an interpretive nature made available to the public outside the formal USGS publications series. Copies are reproduced on request unlike formal USGS publications, and they are also available for public inspection at depositories indicated in USGS catalogs.

Open-File Reports include unpublished manuscript reports, maps, and other material that are made available for public consultation at depositories. They are a nonpermanent form of publication that may be cited in other publications as sources of information.

\section{Maps}

Geologic Quadrangle Maps are multicolor geologic maps on topographic bases in 71/2- or 15-minute quadrangle formats (scales mainly $1: 24,000$ or $1: 62,500$ ) showing bedrock, surficial, or engineering geology. Maps generally include brief texts; some maps include structure and columnar sections only.

Geophysical Investigations Maps are on topographic or planimetric bases at various scales; they show results of surveys using geophysical techniques, such as gravity, magnetic, seismic, or radioactivity, which reflect subsurface structures that are of economic or geologic significance. Many maps include correlations with the geology.

Miscellaneous Investigations Series Maps are on planimetric or topographic bases of regular and irregular areas at various scales; they present a wide variety of format and subject matter. The series also includes 7 1/2-minute quadrangle photogeologic maps on planimetric bases which show geology as interpreted from aerial photographs. Series also includes maps of Mars and the Moon.
Coal Investigations Maps are geologic maps on topographic or planimetric bases at various scales showing bedrock or surficial geology, stratigraphy, and structural relations in certain coal-resource areas.

Oil and Gas Investigations Charts show stratigraphic information for certain oil and gas fields and other areas having petroleum potential.

Miscellaneous Field Studies Maps are multicolor or black-andwhite maps on topographic or planimetric bases on quadrangle or irregular areas at various scales. Pre-1971 maps show bedrock geology in relation to specific mining or mineral-deposit problems; post-1971 maps are primarily black-and-white maps on various subjects such as environmental studies or wildemess mineral investigations.

Hydrologic Investigations Atlases are multicolored or black-andwhite maps on topographic or planimetric bases presenting a wide range of geohydrologic data of both regular and irregular areas; principal scale is $1: 24,000$ and regional studies are at $1: 250,000$ scale or smaller.

\section{Catalogs}

Permanent catalogs, as well as some others, giving comprehensive listings of U.S. Geological Survey publications are available under the conditions indicated below from the U.S. Geological Survey, Books and Open-File Reports Section, Federal Center, Box 25425, Denver, CO 80225. (See latest Price and Availability List.)

"Publications of the Geological Survey, 1879-1961" may be purchased by mail and over the counter in paperback book form and as a set of microfiche.

"Publications of the Geological Survey, 1962- 1970" may be purchased by mail and over the counter in paperback book form and as a set of microfiche.

"Publications of the U.S. Geological Survey, 1971-1981" may be purchased by mail and over the counter in paperback book form (two volumes, publications listing and index) and as a set of microfiche.

Supplements for $1982,1983,1984,1985,1986$, and for subsequent years since the last permanent catalog may be purchased by mail and over the counter in paperback book form.

State catalogs, "List of U.S. Geological Survey Geologic and Water-Supply Reports and Maps For (State)," may be purchased by mail and over the counter in paperback booklet form only

"Price and Availability List of U.S. Geological Survey Publications," issued annually, is available free of charge in paperback booklet form only.

Selected copies of a monthly catalog "New Publications of the U.S. Geological Survey" available free of charge by mail or may be obtained over the counter in paperback booklet form only. Those wishing a free subscription to the monthly catalog "New Publications of the U.S. Geological Survey" should write to the U.S. Geological Survey, 582 National Center, Reston, VA 22092.

Note.--Prices of Government publications listed in older catalogs, announcements, and publications may be incorrect. Therefore, the prices charged may differ from the prices in catalogs, announcements, and publications. 


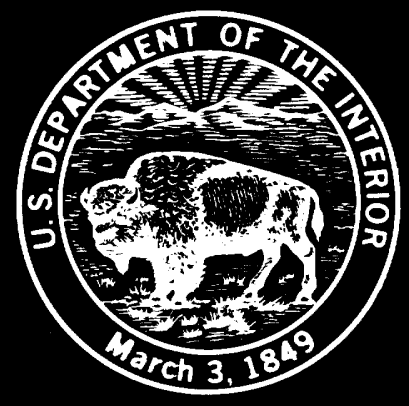

